\title{
ELECTROCHEMICAL REMOVAL OF ZINC AND NICKEL IONS FROM WASTEWATER USING FLAT PLATE ELECTRODES
}

\author{
by \\ Rehan Muhammad Khan, M.Sc. \\ Karachi University, Pakistan, 1994.
}

\author{
A project report \\ presented to Ryerson University \\ in partial fulfillment of the \\ requirements for the degree of \\ Master of Engineering \\ in the program of \\ Chemical Engineering
}

Toronto, Ontario, Canada, 2005

(C) Rehan Muhammad Khan 2005 


\section{UMI Number: EC53038}

\section{All rights reserved \\ INFORMATION TO USERS}

The quality of this reproduction is dependent upon the quality of the copy submitted. Broken or indistinct print, colored or poor quality illustrations and photographs, print bleed-through, substandard margins, and improper alignment can adversely affect reproduction.

In the unlikely event that the author did not send a complete manuscript and there are missing pages, these will be noted. Also, if unauthorized copyright material had to be removed, a note will indicate the deletion.

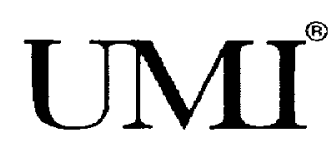

UMI Microform EC53038

Copyright 2008 by ProQuest LLC

All rights reserved. This microform edition is protected against unauthorized copying under Title 17, United States Code.

ProQuest LLC

789 East Eisenhower Parkway

P.O. Box 1346

Ann Arbor, Ml 48106-1346 


\section{Author's Declaration}

I hereby declare that I am the sole author of this thesis.

I authorized Ryerson University to lend this thesis to other institution or individual for the purpose of scholarly research.

Rehan Muhammad Khan

I further authorized Ryerson University to reproduce this thesis by photocopying or by other means, it total or in parts, at the request of other institution or individual for the purpose of scholarly research.

Rehan Muhammad Khan 


\begin{abstract}
Simulated wastewater containing $20 \mathrm{ppm}$ of $\mathrm{Zn}^{++}, 20 \mathrm{ppm}$ of $\mathrm{Ni}^{++}$was treated using an electrochemical technique. This synthetic wastewater was used to simulate the wastewater from metal finishing industries. A rectangular bath integrated with an electrochemical cell consisting of flat plate electrodes (the stainless steel anode and aluminum cathode) was used in the treatment. Potassium sulfate was used as a supporting electrolyte to enhance the removal of $\mathrm{Zn}^{++}$and $\mathrm{Ni}^{++}$. The effects of volumetric liquid flux, $\mathrm{pH}$ and electrode surface area on $\mathrm{Zn}^{++}$and $\mathrm{Ni}^{++}$removal were investigated. All experiments were performed at $25^{\circ} \mathrm{C}$ and at an applied voltage of $4 \mathrm{~V}$. When volumetric flux was raised from 0.0092 to $0.0277 \mathrm{~m}^{3} \cdot \mathrm{m}^{-2} \cdot \mathrm{s}^{-1}$, an increasing trend of the $\mathrm{Zn}^{++}$and $\mathrm{Ni}^{++}$removal was observed. The maximum metal removal was observed at a volumetric liquid flux of $0.0231 \mathrm{~m}^{3} \cdot \mathrm{m}^{-2} \cdot \mathrm{s}^{-1} \cdot \mathrm{Zn}^{++}$ and $\mathrm{Ni}^{++}$were removed by $80 \%$ and $34 \%$, respectively, after 48 hours of electrochemical treatment. Moreover, an increase in the removal of $\mathrm{Zn}^{++}$and $\mathrm{Ni}^{++}$was observed when the $\mathrm{pH}$ was varied from 3.5 to 6.5 . The maximum removal of $\mathrm{Zn}^{++}$and $\mathrm{Ni}^{++}, 97 \%$ and $62 \%$, respectively, occurred at a volumetric liquid flux of $0.0231 \mathrm{~m}^{3} \cdot \mathrm{m}^{-2} \cdot \mathrm{s}^{-1}$ and a $\mathrm{pH}$ of 6.5 . The experimental values showed a similar increasing trend in the removal of $\mathrm{Zn}^{++}$and $\mathrm{Ni}^{++}$, when the electrode surface area was increased from $0.024 \mathrm{~m}^{2}$ to $0.048 \mathrm{~m}^{2}$; the removal of $\mathrm{Zn}^{++}$and $\mathrm{Ni}^{++}$improved by $14 \%$ and $12 \%$, respectively. However, there was no major change in the removal of $\mathrm{Zn}^{++}$and $\mathrm{Ni}^{++}$between flat plate and corrugated plate electrodes.
\end{abstract}




\section{Acknowledgment}

I would like to express my sincere appreciation to Dr. Huu Dung Doan, for his professional support, and understanding. A much added thanks for the time spent in addressing the numerous questions and concerns of the author. The services offered by Mr. Ali Hemmati and Peter Scharping from the Chemical Engineering support services at Ryerson University were greatly appreciated.

My thanks also go to the faculty members and staff of the Department of Chemical Engineering for their contribution to my career development during my program in the University. 


\section{Table of Content}

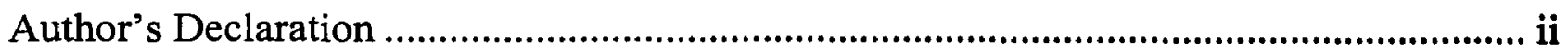

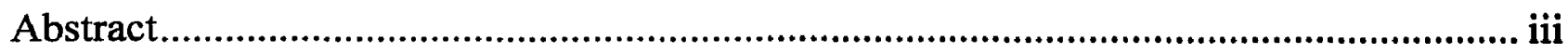

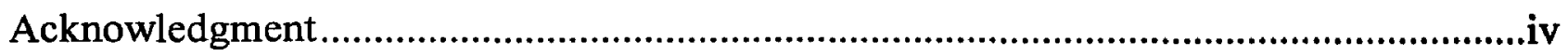

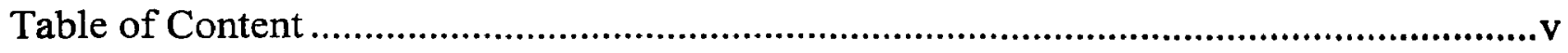

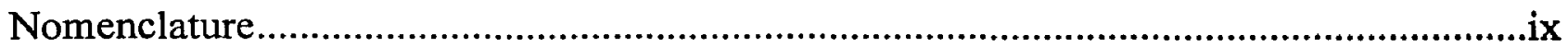

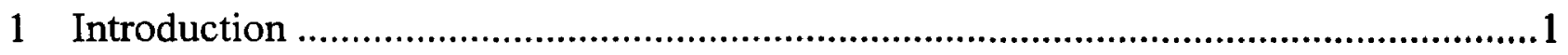

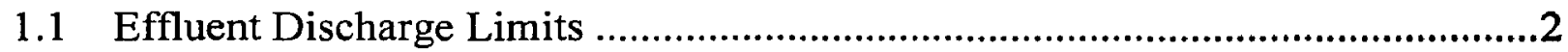

1.2 Conventional Treatment Techniques............................................................2

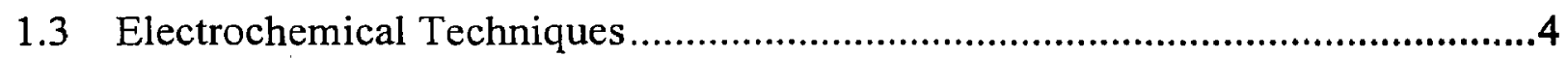

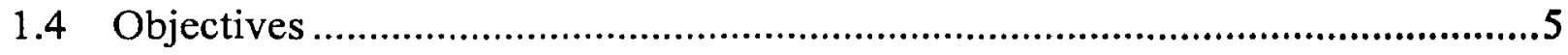

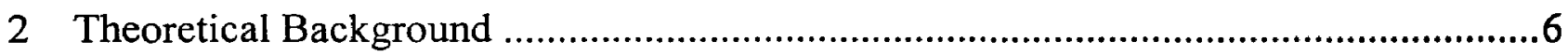

2.1 Parameters Affecting an Electrochemical Process .............................................6

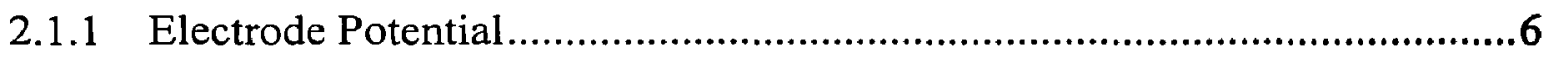

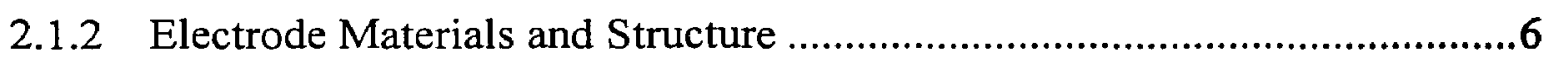

2.1.3 The Concentration of Electroactive Species...............................................6

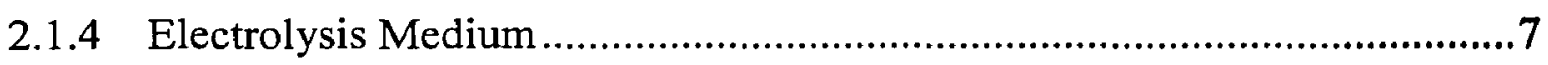

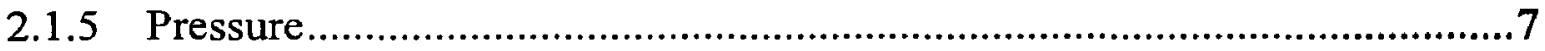

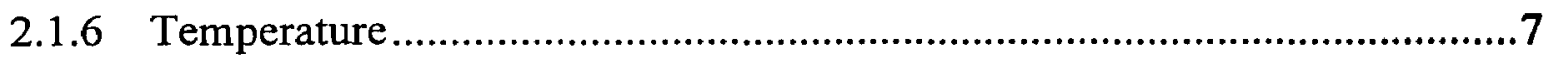

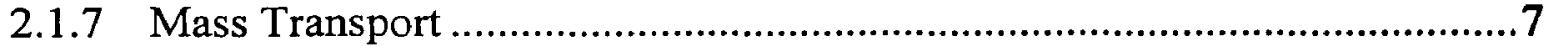

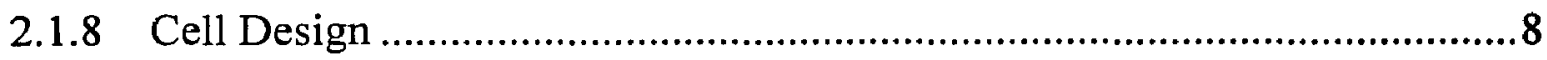

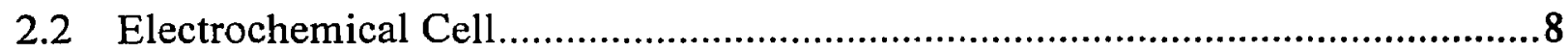

2.3 Thermodynamics and Kinetics of Electrochemical Cell .....................................9

2.4 Mass Transport in Electrochemical Cell ........................................................12

2.5 Interaction between Electron Transfer and Mass Transfer................................13

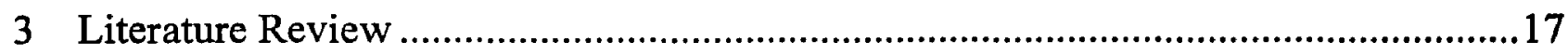

3.1 Electrochemical Reactors for Heavy Metal Recovery .....................................17

3.2 Flat Plate Electrode and Mass Transport Studies ................................................18

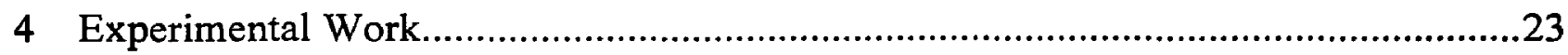

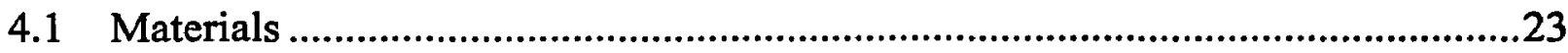




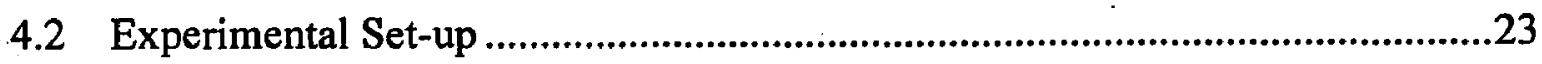

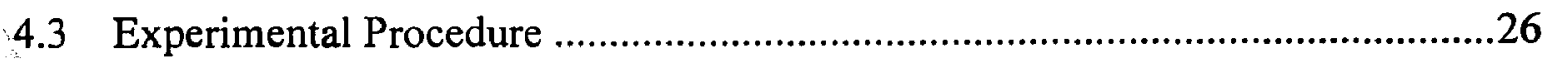

4.3.1 Cleaning before Experimental Run .........................................................26

4.3.2 Preparation of Simulated Wastewater ......................................................26

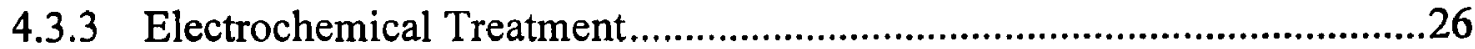

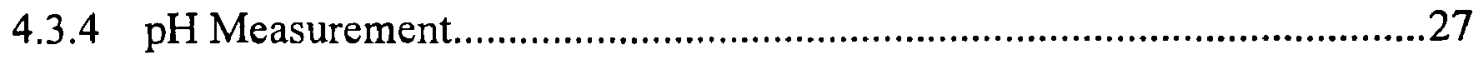

4.3.5 Measurement of $\mathrm{Ni}^{++}$and $\mathrm{Zn}^{++}$in Wastewater ....................................27

4.4 Viscosity, Density and Reynolds number Calculations.........................................28

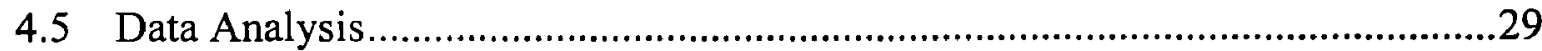

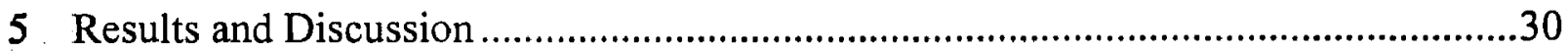

5.1 Effect of Volumetric Liquid Flux ......................................................................30

5.1.1 Anomalous co-deposition ....................................................................40

5.2 Effect of Electrode Surface Area .......................................................................42

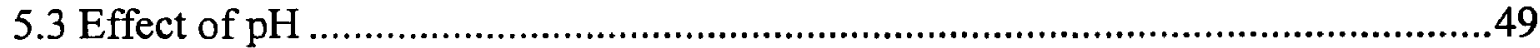

5.4 Comparison of Flat and Corrugated Plate Electrodes ........................................58

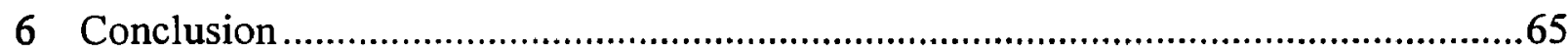

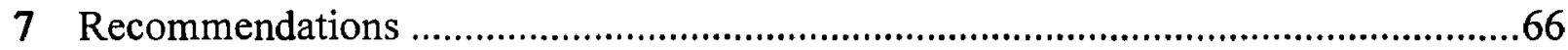

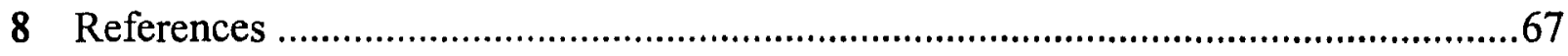

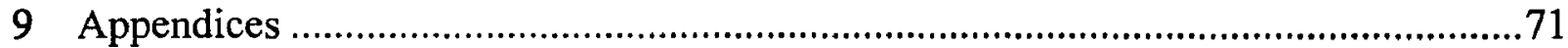

9.1 Appendix A: Summary of Experimental Runs.............................................71

9.1.1 Flat Aluminum Cathode \& Stainless Steel Anode …................................71

9.1.2 Surface area of the Cathode and Anode .....................................................75

9.1.3 The Corrugated Cathode and Anode Plate ................................................76

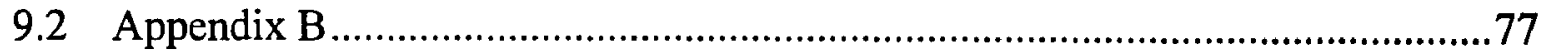

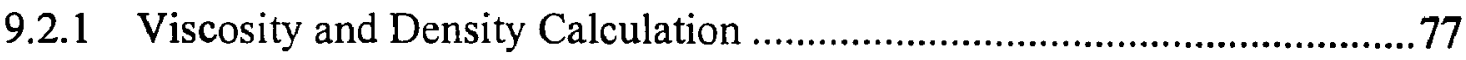

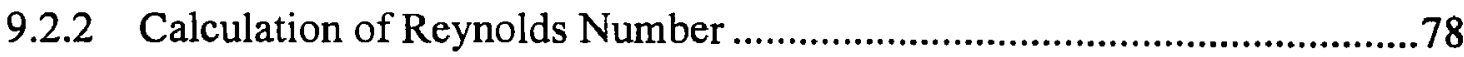

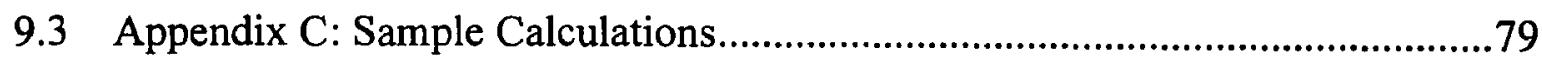

9.3.1 Calculation of the Mass Transfer Coefficient..........................................79

9.3.2 Uncertainty in Mass Transfer Coefficient ...............................................8 


\section{List of Tables}

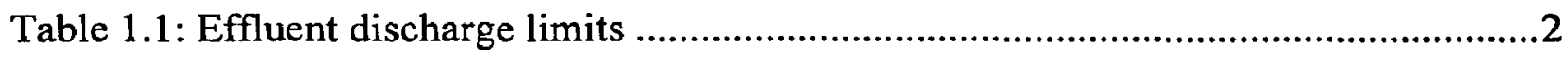

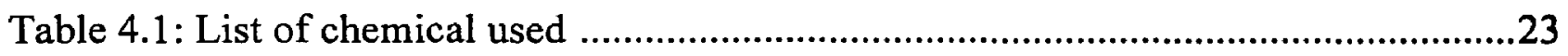

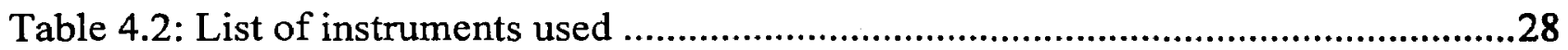

Table 5.1: Apparent rate constants $(k) \&$ mass transfer coefficients $\left(k_{m}\right)$ for $\mathrm{Zn}^{++}$at

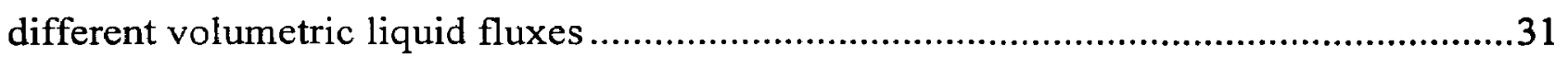

Table 5.2: Apparent rate constants $(k) \&$ mass transfer coefficients $\left(k_{m}\right)$ for $\mathrm{Ni}^{++}$at

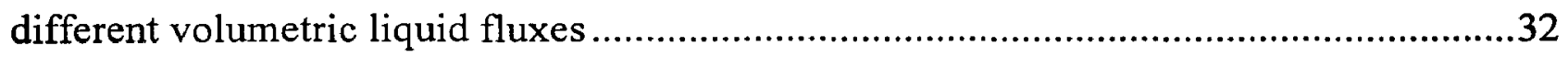

Table 5.3: Apparent rate constants $(k) \&$ mass transfer coefficients $\left(k_{m}\right)$ for $\mathrm{Zn}^{++} \& \mathrm{Ni}^{++}$at

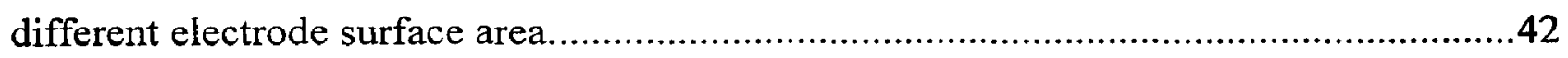

Table 5.4: Apparent rate constants $(k) \&$ mass transfer coefficients $\left(k_{m}\right)$ for $\mathrm{Zn}^{++}$at

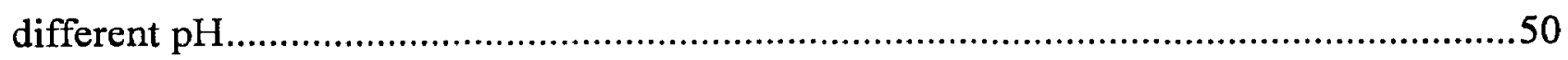

Table 5.5: Apparent rate constants $(k) \&$ mass transfer coefficients $(k m)$ for $\mathrm{Ni}^{++}$at

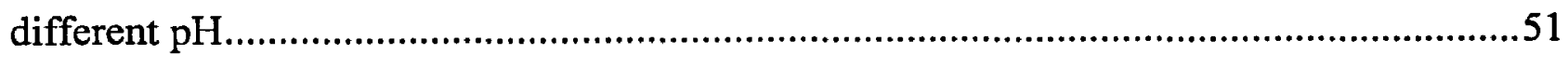

Table 5.6: Apparent rate constants $(k) \&$ mass transfer coefficients $\left(k_{m}\right)$ for $\mathrm{Zn}^{++} \& \mathrm{Ni}^{++}$

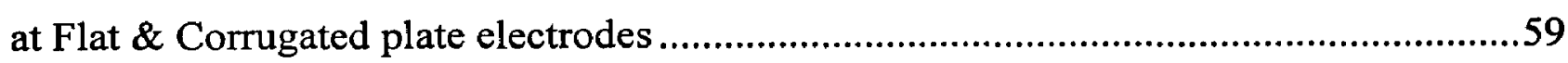




\section{List of Figures}

Figure 2.1: A typical Polarization Curve (Current versus over potential). ..............................15

Figure 3.1: Electrode Arrangements..................................................................................17

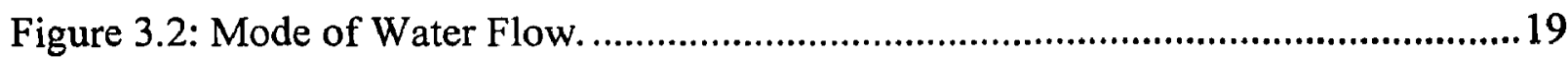

Figure 3.3 Schematic Diagram of Subbaiah Apparatus ...................................................20

Figure 3.4: Schematic Diagram of Oduoza Apparatus.....................................................21

Figure 4.1: Schematic Diagram of Experimental Set-up....................................................24

Figure 4.3: Corrugated plate electrode. ....................................................................25

Figure 5.1: Effect of the volumetric liquid flux on the removal of $\mathrm{Zn}^{++} \ldots \ldots \ldots \ldots \ldots \ldots . . . . . . . . .34$

Figure 5.2: $\ln \left(\mathrm{C} / \mathrm{C}_{0}\right)$ verses $\mathrm{t}^{1 / 2}$ for $\mathrm{Zn}^{++}$at different volumetric liquid flux.....................35

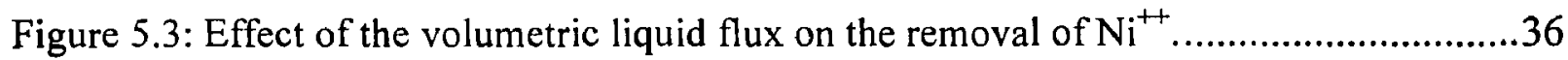

Figure 5.4: $\ln \left(\mathrm{C} / \mathrm{C}_{0}\right)$ verses $\mathrm{t}^{1 / 2}$ for $\mathrm{Ni}^{++}$at different volumetric liquid flux......................37

Figure 5.5: Comparison of the percent reduction of $\mathrm{Zn}^{++} \& \mathrm{Ni}^{++}$at different vol.liquid flux.38

Figure 5.6: Comparison of mass transfer coefficient of $\mathrm{Zn}^{++} \& \mathrm{Ni}^{++}$at different volumetric

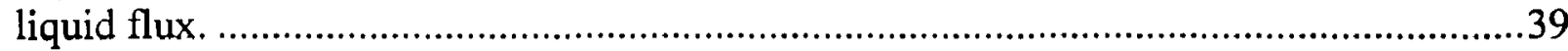

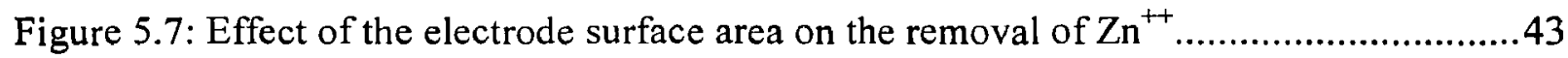

Figure 5.8: $\ln \left(\mathrm{C}_{\mathrm{C}}\right)$ verses $\mathrm{t}^{1 / 2}$ for $\mathrm{Zn}^{++}$at different electrode surface area......................44

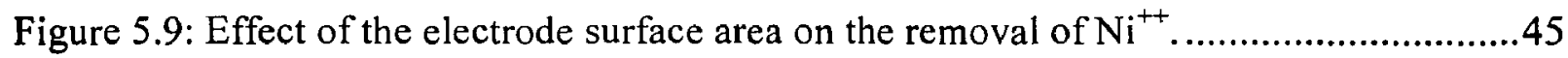

Figure 5.10: $\ln \left(\mathrm{C} / \mathrm{C}_{0}\right)$ verses $\mathrm{t}^{1 / 2}$ for $\mathrm{Ni}^{++}$at different electrode surface area. ....................46

Figure 5.11: Comparison of the removal of $\mathrm{Zn}^{++} \& \mathrm{Ni}^{++}$at different electrode surface area. .47

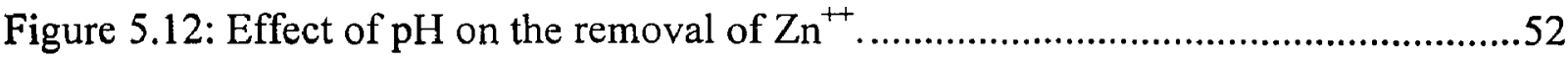

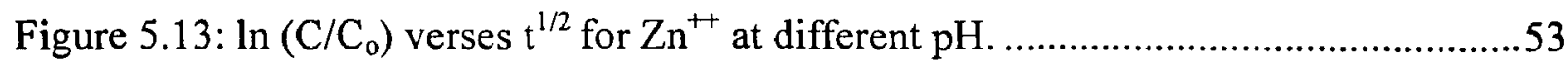

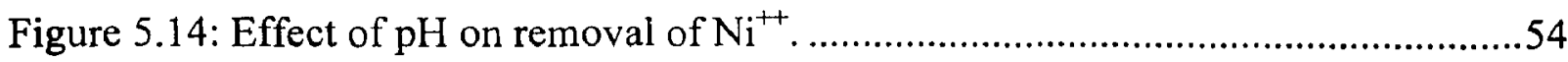

Figure 5.15: $\ln \left(\mathrm{C} / \mathrm{C}_{0}\right)$ verses $\mathrm{t}^{1 / 2}$ for $\mathrm{Ni}^{++}$at different $\mathrm{pH}$..........................................55

Figure 5.16: Comparison of the percent reduction of $\mathrm{Zn}^{++} \& \mathrm{Ni}^{++}$at different $\mathrm{pH}$.............56

Figure 5.17: Comparison of the removal of $\mathrm{Zn}^{++}$with flat $\&$ corrugated plate electrodes .....60 Figure5.18: $\ln \left(\mathrm{C}_{\mathrm{C}} \mathrm{C}_{\mathrm{o}}\right)$ verses $\mathrm{t}^{1 / 2}$ for $\mathrm{Zn}^{++}$with flat \& corrugated plate electrodes.................61

Figure 5.19: Comparison of the removal of $\mathrm{Ni}^{++}$with flat $\&$ corrugated plate electrodes......62

Figure 5.20: $\ln \left(\mathrm{C} / \mathrm{C}_{\mathrm{o}}\right)$ verses $\mathrm{t}^{1 / 2}$ for $\mathrm{Ni}^{++}$with flat $\&$ corrugated plate electrodes.................63

Figure 5.21: Comparison of the percent reduction of $\mathrm{Zn}^{++} \& \mathrm{Ni}^{++}$at flat $\&$ corrugated plate electrodes. 


\section{Nomenclature}

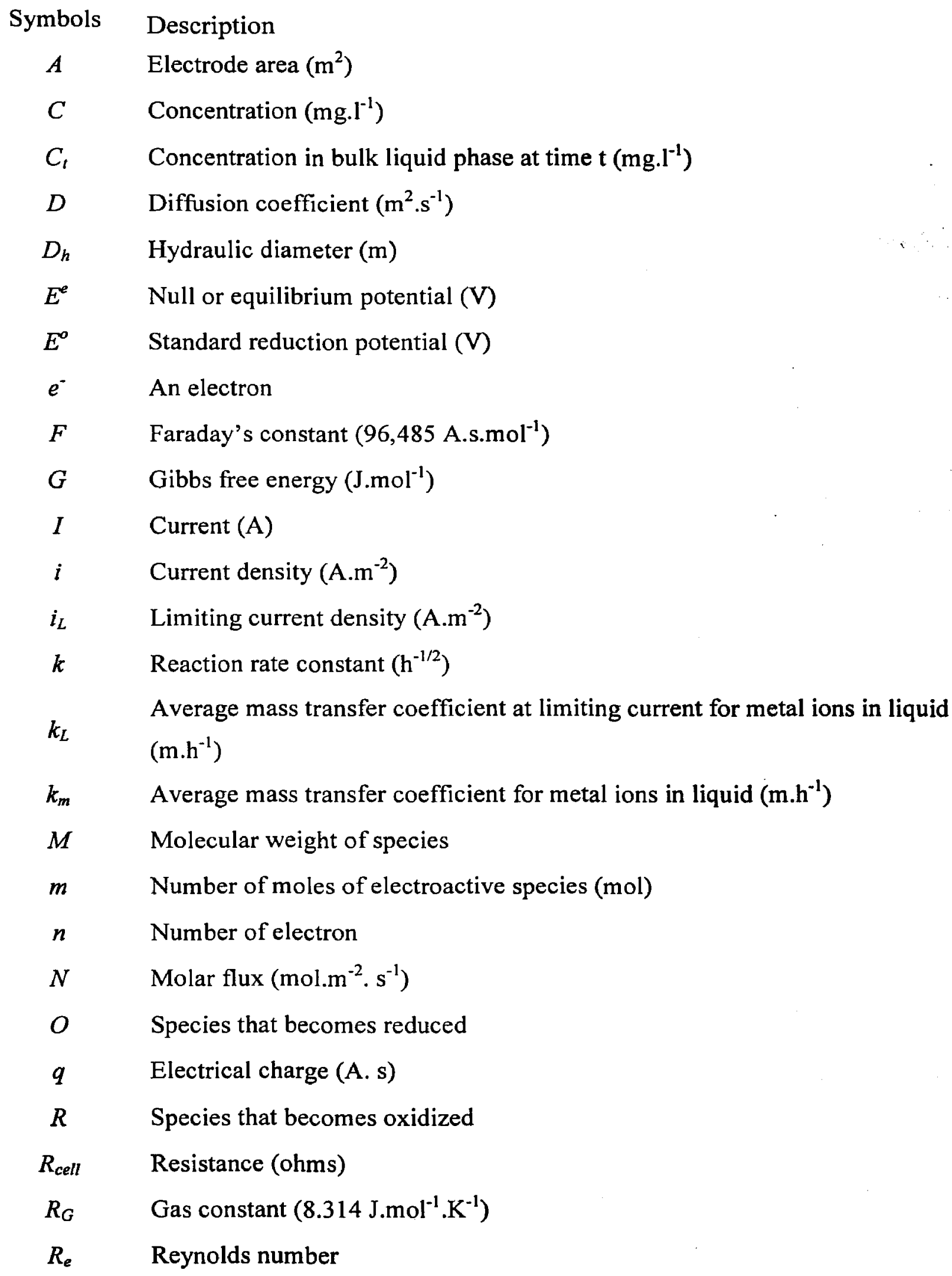




$\begin{array}{ll}T & \text { Temperature (K) } \\ t & \text { Time (h) } \\ u & \text { Velocity of liquid }\left(\mathrm{m} \cdot \mathrm{s}^{-1}\right) \\ V & \text { Volume }\left(\mathrm{m}^{3}\right) \\ Z & \text { Electrical charge number }\end{array}$

\section{Greek Symbols}

$\begin{array}{cl}\mu_{m} & \text { Mobility }\left(\mathrm{m}^{2} \cdot \mathrm{V}^{-1} \cdot \mathrm{s}^{-1}\right) \\ \Phi & \text { Potential field strength }\left(\mathrm{V} \cdot \mathrm{m}^{-1}\right) \\ \eta & \text { Overpotential }(\mathrm{V}) \\ \eta_{\text {act }} & \text { Activation overpotential }(\mathrm{V}) \\ \eta_{\text {conc }} & \text { Concentration overpotential }(\mathrm{V}) \\ \eta_{\text {ohm }} & \text { Ohmic overpotential }(\mathrm{V}) \\ \rho & \text { Liquid Density }\left(\mathrm{kg} \cdot \mathrm{m}^{-3}\right) \\ \mu & \text { viscosity }\left(\mathrm{kg} \cdot \mathrm{m}^{-1} \cdot \mathrm{s}^{-1}\right) \\ \delta & \text { Diffusion layer thickness }(\mathrm{m})\end{array}$

\section{Superscripts}
C, $A$
Cathode, Anode
$\infty$
Bulk value

\section{Subscripts}

$\begin{array}{ll}i & \text { Inlet } \\ L & \text { Limiting } \\ o & \text { Outlet } \\ R & \text { Reduced } \\ s & \text { Surface }\end{array}$

\section{Abbreviations}

ppm Parts per million

PVC Poly vinyl chloride 


\section{Introduction}

The water management is one of the most critical issues in the coming decade. Currently, more than half of the available freshwater is appropriated for human uses [1], indicating a high degree of exploitation of the existing water resources. In future, water resources may even suffer drastic variations on a global level because of the foreseen population growth and climate changes. This fact, in combination with the water pollution caused by mankind activity, makes water re-use of utmost importance. However, one should keep in mind from global prospect that recycling of water is not environmentally benign if highenergy input technologies are used for this purpose [2]. Thus, the development of efficient wastewater treatment technologies with low energetic and operational costs is essential for all types of wastewater.

According to its origin wastewater can be divided into four broad categories, namely domestic, industrial, public service and system loss/leakage. Among these, industrial wastewater contributes $42.4 \%$ of the total volume of wastewater in the world [3].

The major types of pollutants found in industrial wastewater are heavy metals and organic matter. The increasing levels of heavy metals, such as Arsenic (As), Barium (Ba), Cadmium (Cd), Chromium ( $\mathrm{Cr})$, Copper $(\mathrm{Cu})$, Lead $(\mathrm{Pb})$, Silver $(\mathrm{Ag})$, Nickel $(\mathrm{Ni})$ and Zinc ( $\mathrm{Zn})$, in the environment is a serious threat to human health, living resources and ecological systems as these metals are harmful and toxic $[4,5]$.

Effluents from steelworks, rayon yarn and fiber manufacturing, wood pulp production, plating, and metal processing industry contain zinc. Likewise, wastewater streams from metal processing industries, steel foundries, motor vehicle and aircraft industries, printing and chemical industries contain nickel [6].

The present study deals with the electrochemical treatment of the wastewater generated from an automotive industry. In this industry, electrocoating process used to provide a protective polymer coating on the frames of the automobiles and other interior and exterior parts. During the electrocoating process, the parts are cleaned and treated several 
times, generating a large amount of wastewater. In automotive industry, which is one of the major manufacturing sectors in southern Ontario, the electro coating process usually generates, on an average, 0.25 gallons of wastewater per square foot of the metal parts being processed. The wastewater flow rate exiting an automotive plant can be very large, e.g. 1.4 million gallons of wastewater is generated per day at the Toyota plant in Georgetown, Kentucky [7].

\subsection{Effluent Discharge Limits}

Due to rapid increase in the quantities of industrial wastewater, the effluent discharge limits are becoming ever more stringent. Table 1.1 shows the effluent discharge limits for $\mathrm{Zn}^{++}$and $\mathrm{Ni}^{++}$as imposed by the City of Toronto and United States Environmental Protection Agency $[8,9]$.

Table 1.1: Effluent discharge limits

\begin{tabular}{|l|c|c|}
\cline { 2 - 3 } \multicolumn{1}{c|}{} & \multicolumn{2}{c|}{ Parameter $\left(\mathrm{mg} \cdot \mathrm{l}^{-1}\right)$} \\
\hline Jurisdiction & Zinc & Nickel \\
\hline $\begin{array}{l}\text { City of Toronto: Sewer-use } \\
\text { - Storm: }\end{array}$ & 0.04 & 0.08 \\
- Sanitary & 2 & 2 \\
\hline $\begin{array}{l}\text { US EPA: guidelines and standard } \\
\text { For the metal products \& machinery } \\
\text { point source category [8]: }\end{array}$ & & \\
- Storm & 0.08 & 1.9 \\
- Sanitary & 0.35 & 1.5 \\
\hline
\end{tabular}

\subsection{Conventional Treatment Techniques}

The conventional methods for the treatment of wastewater are ion exchange, reverse osmosis and chemical precipitation [10]. 
In ion exchange process, metal ions are removed from the aqueous phase by exchange of cations or anions between the contaminants and the exchange medium. Ion exchange materials are resins made from synthetic organic materials that contain ionic functional groups, inorganic and natural polymeric materials. After a resin's capacity has been exhausted, it can be regenerated for re-use [11]. This method is simple, efficient and generates low sludge. However, one limitation of this method is that large amount of wastewater is generated during the regeneration step that requires additional treatment and disposal [12].

Reverse osmosis is a semi-permeable membrane based treatment process used for removal of particulates, organic material, and metals. Although this method is very efficient, the high cost of the membranes used in the processes makes it very uneconomical [13].

Among the aforementioned methods, chemical precipitation is most widely used because of its simplicity and low capital cost [14]. In this method, metal ions are precipitated as hydroxides, carbonates, or sulfides. Hydroxide precipitation is more common, which uses calcium, sodium or magnesium hydroxide. The hydroxide is added to a mechanically stirred tank to precipitate metal ions as metal hydroxides from wastewater. The required $\mathrm{pH}$ for precipitation process is between 8.5 and 10, depending on the types of metal ions in wastewater. In order to increase particle size and improve the settling characteristics of the metal hydroxides, coagulating and flocculating agents are added, usually in a second tank with slow mixing. The $\mathrm{pH}$ of the treated wastewater should be adjusted around 7 before discharging it to the municipal sewer. In practice, if zinc is the only metal to be removed, a concentration of $0.5 \mathrm{mg} .1^{-1}$ using calcium hydroxide as the precipitating agent is achievable. On the other hand, if nickel is the only metal to be removed a concentration of $0.5 \mathrm{mg} . \mathrm{l}^{-1}$ can be achieved using sodium sulfate as the precipitating agent [15].

However, the major drawback of this method is the generation of large amounts of concentrated sludge, which is buried in landfills. In most of the cases high cost of further treatment of sludge prior to disposal is another disadvantage of this method. [16]. 


\subsection{Electrochemical Techniques}

Metal ions in the wastewater can be treated by electrochemical methods. Most common methods for the electrochemical treatment of wastewater are electrodeposition, electrowining, electrodialysis, electroflotation and electrocoagulation.

Some prominent features of these methods are $[14,17]$ :

- High efficiency

- Versatility

- Amenability to atomization

- Lack of sludge to dispose of

- Possibility of recovering pure metals

Electro-deposition is the deposition of a metallic coating on an object. Electro-deposition is achieved by passing an electric current through a solution containing dissolved metal ions and the metal object to be plated. In an electrochemical cell, the metal object serves as the cathode, which attracts metal ions from the solution. This method is also referred to as electroplating. Ferrous and non-ferrous metal objects are plated by a variety of metals including aluminum, tin, copper, etc., as well as precious metal such as gold, platinum and silver $[18,19]$.

Electrowining is widely used in the mining industry to extract dissolved metals from ore leaching liquid at a concentration of $1000 \mathrm{ppm}$ or higher. This method is also used to remove metal ions from liquid wastes $[20,21]$.

In electrodialysis process, electrically charged membranes are used to remove metal ions from an aqueous solution. This separation process can be used to remove ions from concentrated ionic solution, deionized salt solution, and separate ionic and non-ionic species [22].

Electroflotation is the process of removing dispersed particles in liquid using gas bubbles that are generated by the electrolysis of water $[17,23]$. 
Electrcoagulation utilizes direct current to create sacrificial ions from electrodes. The sacrificial ions remove undesirable contaminants in the wastewater either by chemical reaction and precipitation, or by causing colloidal material to coalesce, which can then be removed by flotation $[9,15,21]$.

Further research in the field of metal recovery from wastewater depends on the design of electrochemical reactors with enhanced space-time yield, and the development of high surface area electrodes with improved mass transfer characteristics.

\subsection{Objectives}

The wastewater generated from an electro-coating process typically contains nickel and zinc ions. This wastewater can be treated by electrodeposition. The electrochemical treatment of wastewater containing nickel and zinc ions was previously investigated by Doan et al. [17], who used a packed column consisting of flat plate electrodes in a flowby configuration. They studied the effect of $\mathrm{pH}$ and applied voltage on the removal of zinc and nickel ions from wastewater.

The present study employs rectangular bath, with flat plate electrodes in a flow-by configuration, for the treatment of simulated wastewater containing nickel and zinc The main objectives of this project are:

- To investigate the simultaneous removal of $\mathrm{Zn}^{++}$and $\mathrm{Ni}^{++}$from simulated wastewater using the electrodeposition method using different volumetric liquid fluxes and $\mathrm{pH}$.

- To determine the rate constant and mass transfer coefficient of zinc and nickel ions.

- To compare the removal of zinc and nickel ions using flat plate and corrugated plate electrodes. 


\section{Theoretical Background}

The study of the movement and separation of charge in matter is called electrochemistry. Electrochemical processes are of heterogeneous nature, in which chemical reactions take place at the interface of the electrode and the electrolyte. The main advantage of an electrochemical process is that it is environment friendly, since the main reagent, the electron, is a "clean reagent".

\subsection{Parameters Affecting an Electrochemical Process}

The main parameters affecting the performance of electrochemical system are discussed in the following section [24]:

\subsubsection{Electrode Potential}

The electrode potential determines the nature of electron transfer reactions occurring in an electrochemical cell. It also determines their absolute rates, i.e. current densities. The potential or current density is, in many cases, a major factor controlling the current efficiency, the space-time yield and the product quality.

\subsubsection{Electrode Materials and Structure}

The ideal electrode material for most processes should be totally stable in the electrolysis medium and permit the desired reaction with a high current efficiency at lower potential. In a few processes, the anodic reaction is the dissolution of a metal (e.g. plating or refining) and this reaction occurs with the same current efficiency as the cathodic deposition so as to maintain the electrolyte composition constant; again, the overpotential should be as low as possible.

\subsubsection{The Concentration of Electroactive Species}

The concentration of the electroactive species is the major parameter that determines the maximum feasible current density and, hence, the optimum space-time yield. The current is normally proportional to concentration and, therefore, the concentration of electroactive species will also be as high as possible in most systems, being limited only by cost, solubility or post-electrolysis process requirements. 


\subsubsection{Electrolysis Medium}

The properties of the electrolysis medium are determined by the choice of solvent, electrolytes and $\mathrm{pH}$, and perhaps also by complexing agents, additives and reagents present to react with intermediates produced in the electrode reaction. The concentration of each constituent is also important. Water with a high concentration of electrolyte is certainly the medium of choice for an industrial electrolytic process, with molten salts a second best if their use is essential to the process. The other constituents of electrolysis medium are chosen on the basis of cost and their effectiveness in meeting the needs of a particular process.

\subsubsection{Pressure}

Electrolysis at elevated or reduced pressures is generally avoided because of the complexity of cell design. The large-scale examples of electrochemistry, much above atmospheric pressure, are mainly limited to special water electrolyzers and battery systems. However, if volatile solvents are utilized, an increased pressure may be desirable to minimize solvent loss, with its attendant cost, health and safety problems.

\subsubsection{Temperature}

For a design of electrochemical system, temperature is another important parameter. Temperatures above ambient are usually employed because of their beneficial effects on the kinetics of an electrochemical process. The diffusion coefficient, the exchange current density and the rates of chemical reactions generally increase with an increase in the temperature. The resulting decrease in the viscosity and increase in the diffusion coefficient serve to enhance mass transport rates. In any case, the passage of current through most cells leads to Joule heating and extensive cooling may be necessary to maintain the cell at room temperature. Again, in the case of volatile solvents, or thermally unstable reactants/products, forced cooling of the electrolyte may be essential.

\subsubsection{Mass Transport}

The mass transport regimes used in industrial processes range from natural convection and diffusion in unstirred electrolytes to highly turbulent conditions produced by rapid 
stirring, or pumping or using turbulence promoters such as a bed of particles. A high liquid flow rate is commonly used because it increases mass transport and, ultimately increases the current density at any potential, and finally leads to a greater uniformity of concentration in the reaction layer adjacent to the electrode surface.

\subsubsection{Cell Design}

The design of the cell affects all the figures of merit for an electrolytic process. It should be noted here that the principal factors determining the electrolysis performance are presence or absence of a separator and its type, and the mass transport regime. The arrangement and form of the electrodes (the anode-cathode gap and potential distribution at both electrodes) and the materials of construction also affect the electrolytic process.

\subsection{Electrochemical Cell}

The oxidation-reduction reactions occurring in an electrochemical cell are heterogeneous in nature. These reactions occur on the electrode surface. In these reactions, there is a loss of electrons by one species and a gain of electrons by another species. The species that gains electrons has a reduction in its oxidation number, while the species that loses electrons has an increase in its oxidation number. A general expression that describes a half-reaction of an oxidation-reduction reaction where species $O$ is reduced to species $R$ can be expressed as follows:

$$
O+n e^{-} \leftrightarrow R
$$

A typical electrochemical cell consists of electrodes (cathode and anode), electrolyte and external wiring and loads. The oxidation of a species occurs at the anode while the reduction occurs at the cathode. Equation (2.1) describes the reaction at the cathode. The opposite of this equation occurs at the anode, where species $R$ loses electrons to become oxidized to $O$. These coupled reactions produce an electric current, that is, the flow of electrons through a circuit, either spontaneously or non-spontaneously. The spontaneity of such reactions is defined by the Gibbs free energy change of the system [24]. 


\subsection{Thermodynamics and Kinetics of Electrochemical Cell}

These oxidation-reduction reactions produce current, which flows through an external circuit. The potential of the electrochemical cell, electromotive force, can be calculated from the equilibrium reduction electrode potentials of the respective half reactions, which are obtained from Nernst equation [25].

$$
E_{c e l l}^{e}=E_{C}^{e}-E_{A}^{e}=E_{\min }^{e}
$$

The equilibrium cell potential $\left(E_{\text {cell }}^{e}\right)$ is referred to as the difference between the equilibrium electrode potentials of the cathode $\left(E_{C}^{e}\right)$ and the anode $\left(E_{A}^{e}\right) . \mathrm{E}_{\text {cell }}$ is the minimum voltage requirement for the above overall cell reactions. A natural process occurs, if and only if, the associated change in Gibbs free energy $(\Delta G)$ for the system is negative. The cell potential is related to $\Delta G$ of the overall cell reaction by the following equation.

$$
\Delta G=-n F E_{\text {Cell }}^{e}
$$

As a result, the value of the $E_{\text {cell }}$ should be positive in order to have spontaneous redox reactions at electrodes. If the value of the cell potential is negative, $\Delta G$ will be positive, so that the cell functions spontaneously in the opposite direction. When the $E_{\text {cell }}$ is negative, an external source of energy will be required to provide energy for the spontaneous reverse -reaction. The applied voltage should be larger than the equilibrium cell potential to drive the chemical change.

In this case, we have an electrolytic cell instead of Galvanic cell and it is much used in electrode reactions. The cathode is connected to the negative pole of the direct current source and cations in the electrolyte migrate towards the cathode. The anode is connected to the positive pole of the direct current source and anions migrate towards the anode. 
The following are standard reduction potentials for zinc and nickel at $25^{\circ} \mathrm{C}$ [26].

$$
\begin{array}{lr}
Z n^{++}(a q)+2 e^{-} \rightarrow Z n(s) & E^{o}=-0.76 V \\
N i^{++}(a q)+2 e^{-} \rightarrow N i(s) & E^{o}=-0.23 V
\end{array}
$$

The negative reduction potential in these equations indicates that both species have tendency to readily lose electrons. Based on this, zinc would have a greater tendency than nickel to lose electrons.

If the resulting cell potential is negative the change in Gibbs free energy of the system would be positive indicating a non-spontaneous process. In such a situation, an external power source would be required to provide a potential greater than the potentials that the spontaneous reverse reaction would produce.

Most often, the reduction potentials of the oxidized and the reduced species are not in their standard states. To account for the situation in which the equilibrium potential of the half-reactions are not in their standard states the Nernst equation was developed [24, 25]:

$$
\Delta E^{e}=\Delta E^{o}-\frac{R_{G} T}{n F} \ln \left(\frac{C_{R}}{C_{o}}\right)
$$

The standard electrode potentials apply only to the equilibrium potential of the metals and are the most positive potentials at which metal can be deposited. In actual deposition processes, the deposition potentials are more negative than the standard potentials due to polarization and cell resistance [27]. When there is a net flow of current through the electrode, there will be a shift in the electrodes potential from its equilibrium position. This shift represents an overvoltage that is dependent on resistance of the electrolyte, the activation energy barrier limitations, and the concentration effects through transport limitations. 
The overvoltage is often considered as a sum of these factors:

$$
\eta=\eta_{o h m}+\eta_{a c 1}+\eta_{c o n c}
$$

and is related to electrode potential

$$
E=E_{e}+\eta_{o h m}+\eta_{a c t}+\eta_{c o n c}
$$

The first factor is due to the resistance of the electrolyte between the two electrodes. However, when considering the entire electro-cell as a whole, resistances are also encountered from the electrodes themselves, wiring, and external loads. All these resistances can be lumped together into an overall cell resistance, and represented through Ohm's Law for the cell:

$$
\eta_{\text {ohm }}=I R_{\text {cell }}
$$

The second factor is due to the kinetics of the electrochemical reaction, which is linked to the activation energy of the reaction. Slow kinetics is due to a large activation energy barrier. To overcome slow kinetics either an increase in temperature could be used or an increase in the applied voltage across the electrodes could be used to achieve any appreciable current flow. The activation overvoltage is also linked to the third factor, namely, the concentration overvoltage.

The cell voltage is also influenced by different parameters such as temperature, flow rate, electrode material, and electrolyte composition. It is difficult to predict the required cell voltage analytically and it is not readily used as a primary control parameter. Constant cell voltage is used practically for convenience, but constant electrode potential (potentiostatic) or constant cell current (galvanostatic) is preferable operation mode [24]. 


\subsection{Mass Transport in Electrochemical Cell}

In general, there are three modes of mass transport in electrochemical systems, diffusion, migration and convection [22, 24].

Diffusion is the movement of a species due to concentration gradient and it occurs whenever there is a chemical change at the surface. At the electrode surface (see eq. 2.1), compound $O$ is converted to the product $R$ by a chemical reaction and hence close to the electrode surface a boundary layer is formed. The concentration of $O$ at the surface is lower than in the bulk, hence, $O$ will diffuse toward the electrode.

Migration is the movement of charged species due to a potential gradient.

Convection is of two types, natural and forced. Natural convection arises from small differences in density caused by the chemical change at the electrode surface. Forced convection is defined as the movement of a species due to a mechanical force. Convection is usually induced by stirring, by flowing solution through the cell, or using rotating electrode.

For dilute solutions, mass transfer becomes the dominant factor. In order to obtain any appreciable rate of reaction so that process is viable, a means of increasing the transport of electroactive species towards the electrode surface is required.

The general expression describing the rate or more specifically the flux of the species for a dilute solution is given as the following [28].

$$
\underset{\text { flux }}{N_{i}}=-z_{i} \mu_{i} F c_{i} \nabla \Phi-\underset{\text { migration }}{D_{i} \nabla c_{i}}+\underset{\text { diffusion }}{c_{i} v}
$$

where $N_{i}$ is the flux, $z_{i}$ is the charge on the ion, $u_{i}$ is the mobility, $c_{i}$ is the species concentration, $F$ is the Faraday's constant, $\nabla \Phi$ is the potential gradient, $D_{i}$ is the diffusivity, and $v$ is the bulk fluid velocity. 
In this expression, convection will be the predominant mode of operation. Diffusion is more significant when the study involves investigating the role of diffusion or obtaining diffusion coefficient for a particular system. Furthermore, if the electrolysis is carried out in the solution with a high concentration of an inert electrolyte, most of the charge is carried with the supporting electrolyte, and migration will not have significant effect on transport of electroactive species.

Improving mass transfer by convection cannot entirely eliminate the effect of diffusion on the transfer rate of the species to the electrode surface. There is always a stagnant layer close to the electrode surface, in which diffusion is very important. When the solution is vigorously stirred the thickness of this diffusion layer, also known as Nernst diffusion layer, can be reduced but cannot be eliminated completely.

\subsection{Interaction between Electron Transfer and Mass Transfer}

We need to recognize the nature of electrode reactions. Perhaps the simplest electrode reaction is one which interconvert, at an inert surface, two species $O$ and $R$ which are completely stable and soluble in the electrolytic medium containing an excess of electrolyte which is electroinactive.

$$
O+n e^{-} \leftrightarrow R
$$

The electrode reaction is a sequence of more basic steps to maintain a current that is essential to supply reactant to the electrode surface and to remove the product, as well as for the electron transfer reaction at the surface to occur. The electrode reaction must have three steps [24]:

$$
\begin{aligned}
& O_{\text {bulk }} \underset{\text { transport }}{\operatorname{mass}} O_{\text {electrode }} \\
& O_{\text {electrode }} \underset{\text { transfer (ne }}{\stackrel{\text { electrone }}{\rightarrow}} R_{\text {electrode }} \\
& R_{\text {electrode }} \underset{\text { iransport }}{\stackrel{\text { mass }}{\rightarrow}} R_{\text {bulk }}
\end{aligned}
$$


The rate of reduction and the cathodic current density is determined by the rate of the overall sequence, it must be dependent on the rate of the slowest step.

The current density is indicative of the rate of reaction per unit area of electrode. The transport of electrons in the Equation (2.12b) generates a charge that is indicative of the extent of the electrochemical reaction and is given by Faraday's Law of Electrolysis which relates the charge produced, $q$ to the number of moles, $m$ of reacting species:

$$
q=\int_{0}^{1} i d t=m n F
$$

where $i$ is the current density, $n$ is the number of electrons transferred, $m$ represents the number of moles of electroactive species and, $F$ is the Faraday's constant (96485 A.s.mol ${ }^{-1}$ ).

For a mass transport controlled process this reaction rate will be limited by the rate of transport of the electroactive species to the electrode surface:

$$
i . A=n F N_{o} . A
$$

Where $A$ is the electrode area and $N_{o}$ is the flux of species $O$ as given in Equation (2.12a).

The flux of species $O$ from the bulk of the liquid to the boundary layer is due to convective transport and is given by the following expression:

$$
N_{o}=k_{m}\left(c_{o}^{\infty}-c_{o s}\right)
$$

where $C_{o}^{\infty}$ and $C_{o s}$ are the concentrations of species $O$ in the bulk and at the electrode surface, respectively, $k_{m}$ is the mass transfer coefficient and is given by

$$
k_{m}=\left(\frac{D}{\delta}\right)
$$

where $D$ is the diffusion coefficient and $\delta$ is the Nernst diffusion layer thickness 
Therefore, combining equation (2.14) with equation (2.15) illustrates the relationship between the current and mass transfer (mass transport coefficient) [22]:

$$
i_{(r)}=k_{m} n F\left(c_{o}^{\infty}-c_{o s}\right)
$$

Here, these expressions represent the instantaneous current density at time $t$. When the rate of transport is sufficient enough to provide electroactive species to the electrode surface, the concentration at the surface, $c$, will be zero indicating a fast reaction. In this case the, process is under complete mass transport control, at which point the mass transfer coefficient becomes known as the limiting mass transfer coefficient [29]:

$$
i(t)=i_{L}=k_{L} n F C_{o}^{\infty}
$$

where $k_{L}$ is the average mass transfer coefficient at the limiting current for metal ion in the liquid.

Therefore, the average mass transfer coefficient can be obtained through direct measurement of the limiting current. This procedure is applicable if the bulk concentration of electroactive species does not change during electrolysis. In this case, the graph of current density versus overpotential, also known as a voltamogram, results in a distinct plateau in which the limiting current is reached.

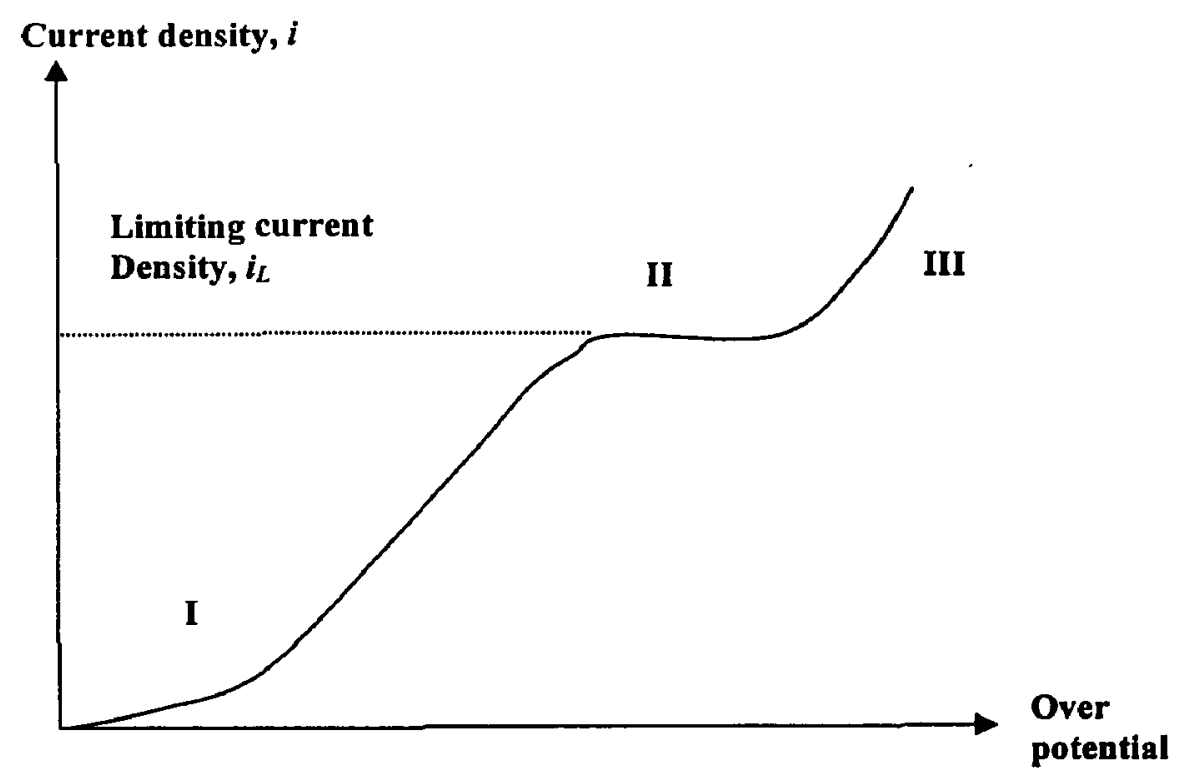

Figure 2.1: A typical Polarization Curve (Current versus over potential) [29]. 
Three different regions are shown in figure 2.1.

Region (I): In this region, the process is both under mass transfer and charge transfer control. In the case of dilute solutions, for the removal of heavy metal ions, the process would occur in this region since the limiting current would not reached.

Region (II): The limiting current can be reached if the bulk concentration of the electroactive species can be kept constant. At the limiting current, the process is completely mass transfer controlled, which is not reached in the case of dilute solutions.

Region (III): At the current density greater than the limiting current, the double layer becomes further charged and other reactions, such as hydrogen evolution, can significantly occur [29].

There are different routes for determination of $k_{m}$ :

1- Via direct measurement of the limiting current.

2- Manipulation of the converted mass and assumption of specific reactor model.

The first method is the most straightforward route. However, using the limiting current is true for systems with constant bulk concentration of the electroactive species. In wastewater treatment processes, the bulk concentration of the electroactive species is reduced over treatment time. Consequently, in the present study, average mass transfer coefficient was determined from the average concentration measurement of the metal ions. 


\section{Literature Review}

\subsection{Electrochemical Reactors for Heavy Metal Recovery}

There are a few types of electrochemical reactors that have found applications in metal recovery, such as tank cells, plate and frame cells, rotating cells, to complicated threedimensional reactor systems like fluidized bed, packed bed cell or porous carbon packing cells.

Tank cells are one of the simplest and the most popular designs. These can be easily scaled up or down depending on the load of a process. The electrode can be arranged in mono-polar or bi-polar mode. Monopolar design (Figure 3.1a) is an arrangement of electrodes in alternating position, such as one anode and one cathode. Bipolar design (Figure $3.1 \mathrm{~b}$ ) is an arrangement of electrodes that are shared by two series-coupled in an electrochemical cell in such a way that one side of the electrode acts as an anode and the other side acts as a cathode. The main application of this type of reactor system is the recovery of metals from high concentration process streams, such as effluents from the electroplating baths, ethants, and eluates of an ion-exchange unit [23].

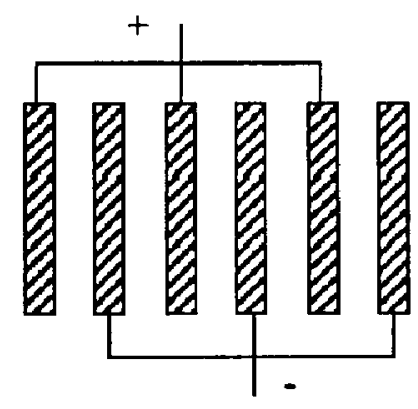

(a) Monopolar

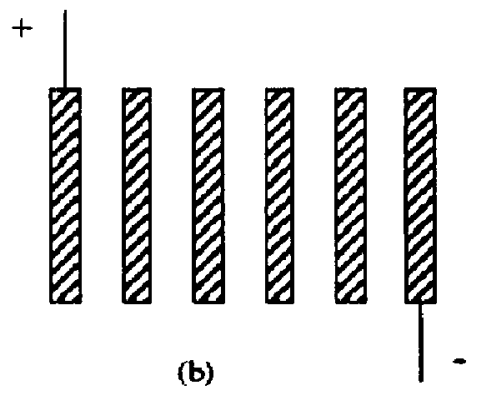

(b) Bipolar

Figure 3.1: Electrode Arrangements [23].

The plate and frame cell, also called filter press is one of the most popular electrochemical reactor designs. It conveniently houses units with an anode, a cathode, and a membrane in one module. This module system makes the design, operation and maintenance of the reactor relatively simple [30]. 
The rotating cathode cell is another form electrochemical reactor. It is designed and employed to enhance mass transfer from the bulk to the electrode surface, and to remove the deposited metal powders from the cathode. The pump cell is another variant of rotating cathode cell. By having a static anode and a rotating disk cathode, the narrow spacing between the electrodes allows the entrance of the effluent [23].

Another form of electrochemical reactor is the packed bed cell. Carbon granules, which are used as the cathode, are packed in the cell. The anode is separated by a diaphragm. This three-dimensional porous, carbon cathode provides 500 times more plating area than conventional two-dimensional cells [31]. In order for dilute metal pollutants to be deposited properly on the cathode, it is suggested to seed metal powders by having concentrated metal solution at the beginning of the recovery process. Control of $\mathrm{pH}$ in the feed tank of a recirculating electrolyte is important to avoid precipitation of the metal.

\subsection{Flat Plate Electrode and Mass Transport Studies}

The electrode system is the most important part in the electrochemical unit. The electrode can be made of iron, aluminum and stainless steel. They are cheap, easily available and good conductors [23].

These flat plate electrodes have some advantages such as [22]:

- Uniform potential and current density distribution.

- High mass transfer rate.

- Small gap between the anode and the cathode, which also reduces cell volume and the ohmic drop.

- Extendable surface area.

Depending on the orientation of the electrode plates, electrochemical cell can be either horizontal or vertical. The electrode plates are usually connected in bipolar mode. The water flows through the space between the plates, which can be multiple channels (Fig.3.2a) or single channel (Fig.3.2b). Multiple channels are simple in flow arrangement but the flow rate in each channel is small. When the electrode surface passivation can not 
be minimized, increasing the flow rate by using a single channel flow is recommended [23].

Roventi et al [32] used the steel discs as electrode for the codeposition of $\mathrm{Zn} \mathrm{\&} \mathrm{Ni}$ alloy from chloride bath. They studied the normal and anomalous codeposition. They found that the deposition of alloys of different composition, morphology and structure depended on the cathodic potential.

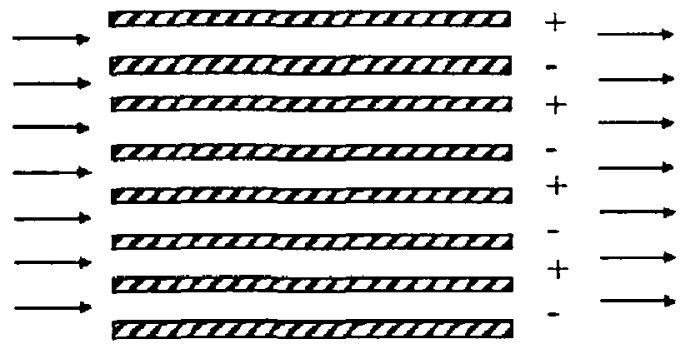

(a) Multiple channel

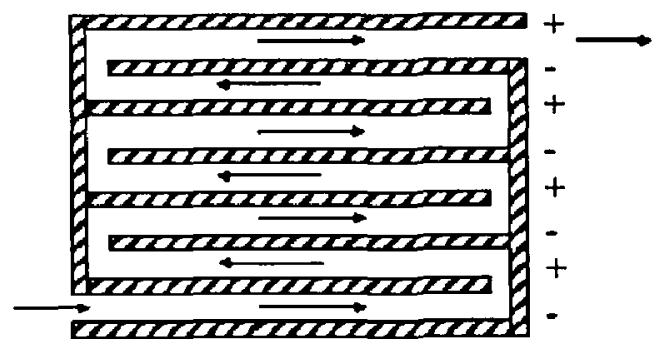

(b) Single channel

Figure 3.2: Mode of Water Flow [23].

Njau et al [33] used the flat plate electrode for the reduction of nickel ion in dilute industrial wastewater. They found that the deposition of metallic nickel, nickel oxide and nickel hydroxide depended on the solution composition and electrolysis condition. Saba et al. used the platinum anode and the aluminum cathode. Removal of heavy metals by steel flat plate electrodes were studied by Szpyrkowicz [34] and Polprasert [16].

Some researchers have used flat plate electrode, with rectangular plat promoters, for increasing the mass transport. These studies may be divided into static or dynamic operation. The first case includes the use of turbulence promoters on static electrodes, whereas the second case includes agitation of the electrolyte through vibration of the electrodes.

Subbaiah et al. [35] focused on mass transfer studies using displaced rectangular plate promoters in an electrolytic cell with flat plate electrodes. Under forced convective flow, the improvement in the mass transfer coefficient was four times higher than that under natural convection. It was determined that under forced convective flow the overall mass 
transfer coefficient varied with the velocity with an exponent of 0.13 for a range of Reynolds number between 100 and 1000.

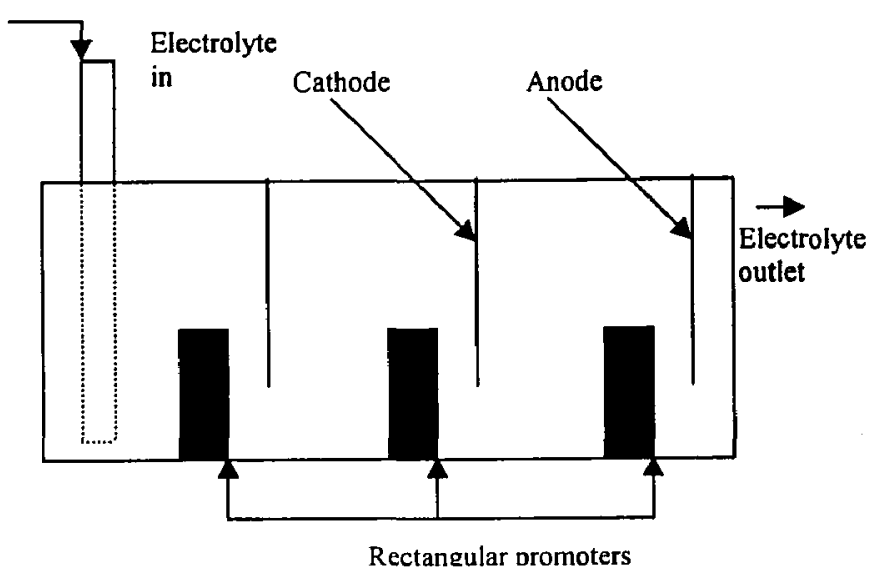

\section{Figure 3.3 Schematic Diagram of Subbaiah Apparatus [35].}

The characteristic length was based on the hydraulic diameter of the flow channel, which was essentially the dimension of the electrocell.

Oduoza et al. [36] also employed turbulence promoters, but instead of having them attached on the bottom of the electro-cell, as was done by Subbaiah et al., rectangular baffles were placed on the frame of the electro-cell. This placement also created a "serpentine flow path." Their study also examined the effect of baffle length on the overall mass transfer coefficient. Figure 3.4 depicts a schematic diagram of their apparatus with nickel flat plates as electrodes. It was concluded that a longer baffle length increased the mass transfer coefficient. The dimensionless correlation obtained indicated a Reynolds number exponent of 0.6 for the range of $2500-20000$ based on the hydraulic diameter.

Other researches have examined the effect that moving electrodes through vibrations have on mass transfer. Buso et al. [37] studied the effect of agitation level on the removal of iodine, by using reciprocating sieve-plate electrodes. It was concluded that the agitation level does increase mass transfer coefficient. Agitation of electrolyte by means 
of vibrating the electrodes was also studied by Panizza et al. [14]. In this study, multiple vibrating flat plate electrodes were used to investigate the effect of removal efficiency of copper from industrial wastewater.

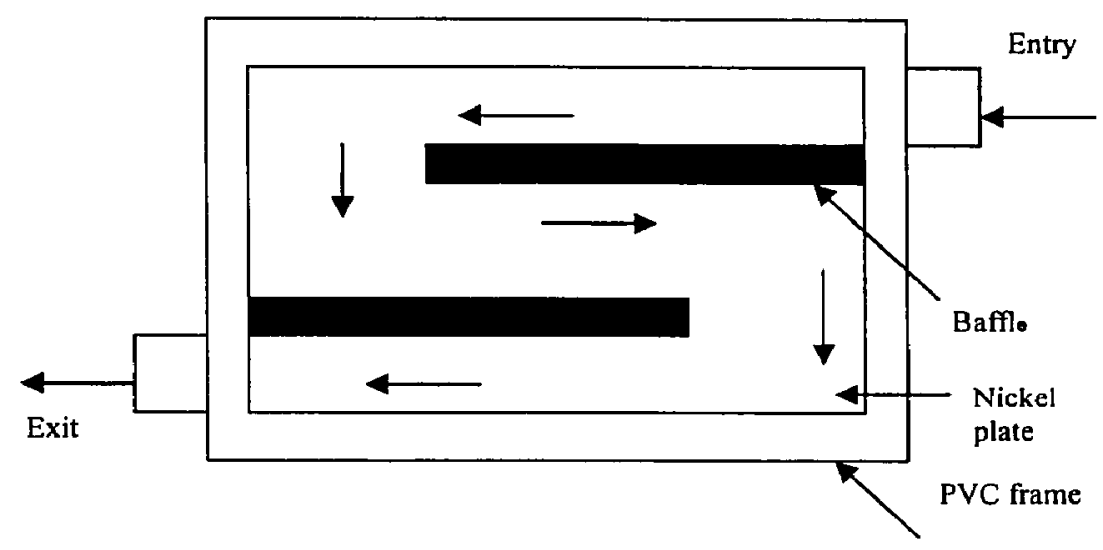

Figure 3.4: Schematic Diagram of Oduoza Apparatus [36].

They examined the effect that flow rate has on the removal efficiency of copper from which it was concluded that flow rate influenced residence time rather than mass transport. The reduction of the copper to meet discharge limits was unattainable even though multiple flat plates would increase the available surface for deposition and increased agitation of the electrolyte caused by the vibration of electrodes would seem to increase mass transport.

The effect of $\mathrm{pH}$ and electrolyte on removal of zinc and nickel was investigated by Doan et al. [17]; they used packed column with flat plat electrode. They found an increase in removal of zinc and nickel with an increase in the $\mathrm{pH}$ of electrolyte. The zinc and nickel were removed $99 \%$ in 42 and 46 hours, respectively, at a pH of 6.05 .

Dutra et al. [21] investigated the removal of cadmium from diluted aqueous solution using flow by cell with RVC cathode. They investigated the effect of volumetric liquid flux and current density on the removal of cadmium. Cadmium was reduced from an initial concentration of 200 to a final concentration of $1 \mathrm{ppm}$. 
Mitzakov [38] used the flat plate electrode in packed column for removal of zinc and nickel. He investigated the effect of volumetric liquid flux and controlled and uncontrolled $\mathrm{pH}$. In laminar region, zinc and nickel were reduced $95 \%$ and $80 \%$, respectively. On the other hand, removal of zinc and nickel decreased in the turbulent region, from $95 \%$ to $82 \%$ and $80 \%$ to $55 \%$, respectively.

Effect of liquid flow rate and applied voltage on recovery of palladium from hydrochloric acid solution was investigated by Kim et al. [39]; they used a modified cyclone reactor that comprised titanium rotating disc electrode, vitreous carbon electrode and saturated calomel reference electrode; compared with laminar flow at $0.6 \mathrm{~m} . \mathrm{s}^{-1}$, the recovery of palladium increased exponentially under the turbulent flow conditions $\left(3.0 \mathrm{~m} \cdot \mathrm{s}^{-1}\right)$.

Njau et al. [33] studied the removal of nickel ions from industrial wastewater on rotating disc electrode. Koene et al. [22] employed the different type of electrodes such as pack bed electrode, rotating cylinder electrode and flat plate electrode for removal of nickel ions. 


\section{Experimental Work}

\subsection{Materials}

Table 4.1 list the chemical used in the present study.

Table 4.1: List of chemical used

\begin{tabular}{|c|c|c|c|c|}
\hline No. & Chemical & Formula & Formula wt. & Manufacturer \\
\hline 1 & Nickel sulfate hexahydrate & $\mathrm{NiSO}_{4} .6 \mathrm{H}_{2} \mathrm{O}$ & 262.85 & J.T. Baker \\
\hline 2 & Zinc sulfate heptahydrate & $\mathrm{ZnSO}_{4} .7 \mathrm{H}_{2} \mathrm{O}$ & 287.56 & J.T. Baker \\
\hline 3 & Potassium sulfate & $\mathrm{K}_{2} \mathrm{SO}_{4}$ & 174.27 & J.T. Baker \\
\hline 4 & Potassium Hydroxide & $\mathrm{KOH}$ & 41.2 & Merck \\
\hline 5 & Sulphuric Acid & $\mathrm{H}_{2} \mathrm{SO}_{4}$ & 98.6 & Merck \\
\hline
\end{tabular}

\subsection{Experimental Set-up}

A schematic representation of the set-up is given in Fig 4.1. The experimental set-up consisted of a rectangular bath, a storage tank, a flow meter (Model F-45750-LHN12, Fabco Plastics, Maple, Ontario) and a pump. The rectangular bath along with the flat plate stainless steel anode and the aluminum cathode formed the electrochemical cell; it was $100 \mathrm{~cm}$ long, $30 \mathrm{~cm}$ wide and $10 \mathrm{~cm}$ high, and was constructed from PVC. The size of each electrode was $20 \mathrm{~cm} \times 6 \mathrm{~cm}$, and the distance between these electrodes was $4 \mathrm{~cm}$. The anode and the cathode were used in a flow-by configuration. In this configuration, the flow of liquid is parallel to the electrode, whereas the flow of current is perpendicular to the solution as well as the electrodes. This configuration allows high product conversion [22]; for this reason, this configuration was chosen for the present study.

A liquid distributor (Figure 4.2), installed at the bottom of the rectangular bath, was used for the uniform distribution of the simulated wastewater within the rectangular bath. 


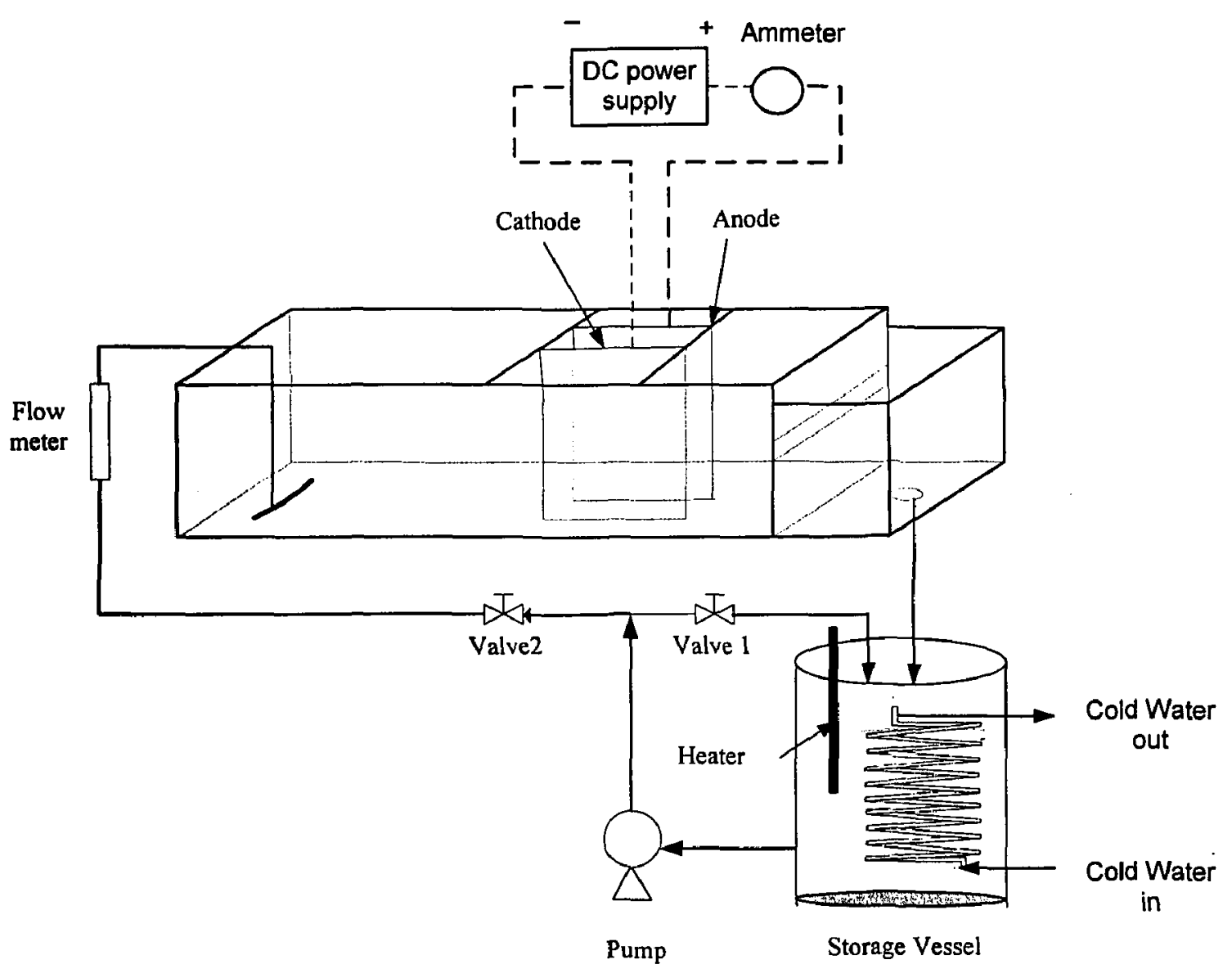

Figure 4.1: Schematic Diagram of Experimental Set-up

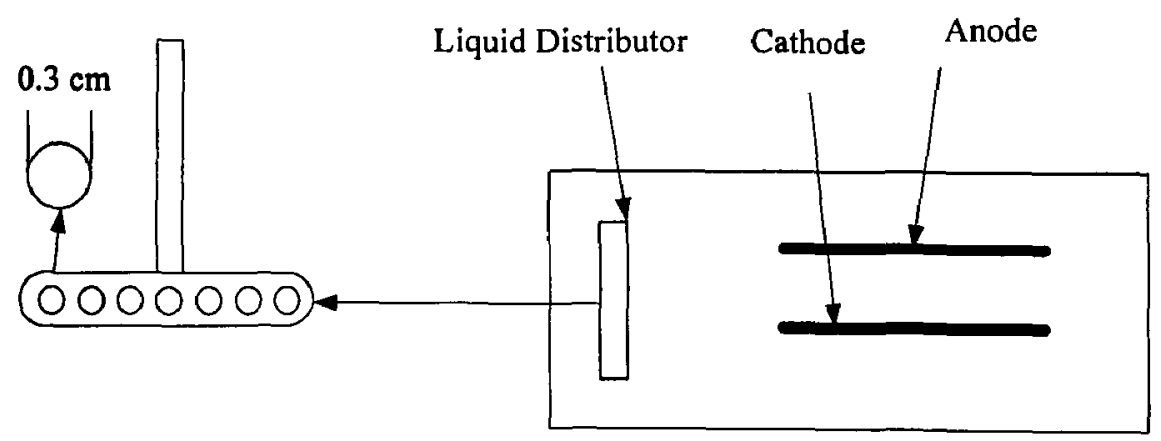

Figure 4.2: Schematic Diagram of Electro-cell 


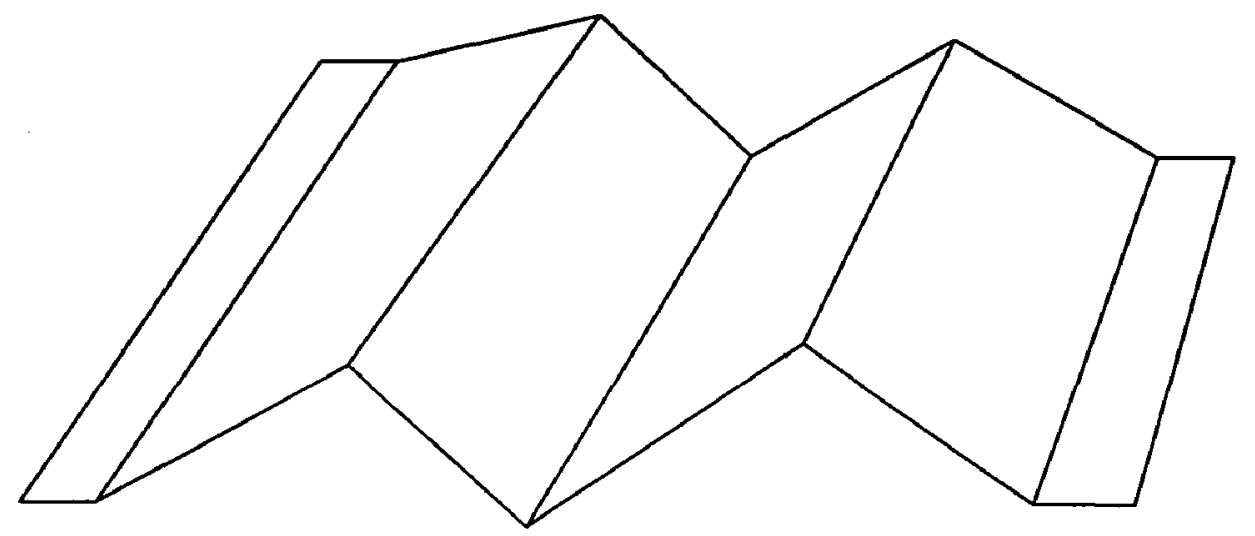

Figure 4.3: Corrugated plate electrode.

The storage vessel, having an internal diameter of $30 \mathrm{~cm}$ and a height $60 \mathrm{~cm}$, was made of polyethylene. It had a copper cooling coil and automatic immersion heater, which were used to maintain the temperature of the simulated wastewater around $25^{\circ} \mathrm{C}$. The flow meter, used for liquid flow measurements, had a range of 0-40 1. $\mathrm{min}^{-1}$.

A direct current power supply (Sargent-Welch Scientific Co.) was used to provide a constant voltage to the electrochemical system. The cathode and the anode were connected to the negative and the positive terminals of the power supply, respectively. An ammeter (Sargent-Welch Scientific Co. 0-150 mA) was connected in series to measure the current.

In the present study, one experimental run was conducted using corrugated stainless steel anode and corrugated aluminum cathode. To construct these electrodes, stainless steel and aluminum plates (each of $20 \mathrm{~cm}$ in length), were corrugated at an angle of $60^{\circ}$. The corrugations formed triangles around an imaginary centre line; each triangle was $1.5 \mathrm{~cm}$ high and $4 \mathrm{~cm}$ wide. The size of these electrode plates after corrugation was $14 \times 6 \mathrm{~cm}$ as illustrated in Figure 4.3. These electrodes were also used in a flow-by configuration; the distance between the corrugated electrodes was $4 \mathrm{~cm}$. 


\subsection{Experimental Procedure}

\subsubsection{Cleaning before Experimental Run}

Prior to any experimental run, the apparatus was cleaned with distilled water; distilled water was flushed through the system for at least 2 hours and then drained.

The anode and cathode were washed by detergent in order to remove grease and oil from it; rinsed with distilled water and fixed it in electrochemical cell

All glassware was cleaned by using mild detergent, followed by at least three rinses with tap water, and then a final rinse with distilled water.

\subsubsection{Preparation of Simulated Wastewater}

The simulated wastewater used for electrochemical treatment had $20 \mathrm{ppm}$ of $\mathrm{Ni}^{++}, 20$ ppm of $\mathrm{Zn}^{++}$and $500 \mathrm{ppm}$ of potassium sulfate. Nickel sulfate hexahydrate and zinc sulfate heptahydrate were used to prepare the simulated wastewater. Potassium sulfate was also added to the solution as a supporting electrolyte. Total volume of the simulated wastewater used for all the runs was 50 liters.

To prepare the simulated wastewater solution, a 4 liters Erlenmeyer flask was used. For $20 \mathrm{ppm}$ of zinc ion concentrations, $20 \mathrm{ppm}$ nickel ion concentration, and $500 \mathrm{ppm}$ of electrolyte, $3.39 \mathrm{~g}$ of zinc sulfate, $3.54 \mathrm{~g}$ of nickel sulfate, and $25.0 \mathrm{~g}$ of potassium sulfate, respectively, were weighed and added to the flask. Then 2 liters of distilled water was added to the flask and the contents were stirred. The solution was then added to the holding tank, already containing 48 liters of distilled water.

\subsubsection{Electrochemical Treatment}

The simulated wastewater was added to the storage vessel and the pump was turned on. The apparatus operated in batch recirculation. The wastewater pumped from the storage vessel would flow thorough the liquid distributor into the rectangular bath, and finally flow back to the vessel. The water was allowed to flow through the apparatus for at least 5 minutes to ensure complete mixing of metal ions and electrolyte. The water valves were 
adjusted to maintain a desired liquid flow rate, the power supply was turned on and its knob was adjusted to supply an applied voltage of $4.0 \mathrm{~V}$. The electrochemical treatment time for any run was 48 hours.

Samples were drawn from the storage vessel at regular time intervals of $0,4,8,24,28,32$ and 48 hours. A100 $\mathrm{ml}$ beaker (VWR, Inc) was used to take grab samples of wastewater from the holding tank. The samples were immediately analyzed for $\mathrm{pH}$ and metal ions concentration Likewise, the current and temperature of the wastewater were measured at the aforementioned time intervals. At the end of 48 hours of electrochemical treatment, the wastewater was drained out from the bottom of the storage vessel. For each run, a new aluminum plate was used as cathode.

\subsection{4 pH Measurement}

The $\mathrm{pH}$ of the sample was measured using a $\mathrm{pH}$ meter (model $230 \mathrm{~A}^{+}$Thermo Orion). The $\mathrm{pH}$ meter was calibrated on daily basis by using buffers of $\mathrm{pH} 4$ and $\mathrm{pH} 7$. During any experimental run, adjustment to the $\mathrm{pH}$ of wastewater was done using $1.0 \mathrm{M}$ potassium hydroxide $(\mathrm{KOH})$ or $1.0 \mathrm{M}$ sulfuric acid $\left(\mathrm{H}_{2} \mathrm{SO}_{4}\right)$.

\subsubsection{Measurement of $\mathrm{Ni}^{++}$and $\mathrm{Zn}^{++}$in Wastewater}

The concentration of $\mathrm{Zn}^{++}$and $\mathrm{Ni}^{++}$in wastewater were analyzed by Orbeco-Hellige Spectrophotometer.

The zincon method was used for the measurement of zinc concentration. The procedure was provided by the manufacturer (model Orbeco-Hellige 975 PM, Orbeco Analytical Systems Inc. Farmingdale, New York). The detection range for zinc was 0 to $4 \mathrm{mg} .1^{-1}$ at a wavelength of $640 \mathrm{~nm}$ according to the manufacturer literature.

Dimethylgloxime (Heptoxime) method was used for the measurement of nickel concentration. The manufacture provided the procedure for this method. According to the manufacturer's manual, the detection range for nickel was 0 to $12 \mathrm{mg}^{-1} \mathrm{l}^{-1}$ at a wavelength of $528 \mathrm{~nm}$. 
Table 4.2 presents the list of instruments used in the present study.

Table 4.2: List of instruments used

\begin{tabular}{|c|c|c|}
\hline Instrument & Model \& Manufacturer & Precision \\
\hline $\mathrm{pH}$ meter & $\begin{array}{c}\text { 220, Corning Inc. Corning } \\
\text { New York }\end{array}$ & \pm 0.01 \\
\hline Spectrophotometer & $\begin{array}{c}\text { Orbeco Hellige 975PM, } \\
\text { Orbeco Analytical Systems } \\
\text { Inc. Farmingdale New York }\end{array}$ & \\
\hline Balance & $\begin{array}{c}\text { Scientech Inc. Boulder } \\
\text { Colorado }\end{array}$ & $\begin{array}{c} \pm 0.0001 \mathrm{~g} \text { high range } \\
\pm 0.001 \mathrm{~g} \text { low range }\end{array}$ \\
\hline
\end{tabular}

\subsection{Viscosity, Density and Reynolds number Calculations}

The dynamic viscosity of the simulated wastewater and density were assumed to be the same as calculated by Mitzakov [38] for the simulated wastewater having $20 \mathrm{ppm}$ of $\mathrm{Zn}^{++}, 20 \mathrm{ppm}$ of $\mathrm{Ni}^{++}$, and $500 \mathrm{ppm}$ of potassium sulfate. Calculation details of the method adopted by Mitzakov are provided in Appendix B.

The Reynolds number was calculated from the following expression describing flow of liquid between parallel plates in a channel [40].

$$
R_{e}=\frac{\rho u D_{h}}{\mu}
$$

In the above expression, $\rho$ is the density of the liquid $\left(\mathrm{kg} \cdot \mathrm{m}^{-3}\right), u$ is the velocity of the liquid $\left(\mathrm{m} . \mathrm{s}^{-1}\right), D_{h}$ is the hydraulic diameter of the electrochemical cell $(\mathrm{m})$ and $\mu$ is the viscosity of the liquid $\left(\mathrm{kg} \cdot \mathrm{m} \cdot \mathrm{s}^{-1}\right)$.

The hydraulic diameter is given by

$$
D_{h}=\frac{4(2 b h)}{2 h+4 b}
$$


Where, $h$ is the height of the plate $(\mathrm{m})$ and $b(\mathrm{~m})$ is distance between the parallel plates.

\subsection{Data Analysis}

Uncertainties associated with the concentrations of zinc and nickel were calculated from multiple readings; all outlier values were discarded and average and standard deviations associated with zinc and nickel were calculated from the remaining data [41]. Similarly, the uncertainties associated with the average mass transfer coefficient were determined from the method of Kline and McClintock [42]. 


\section{Results and Discussion}

\subsection{Effect of Volumetric Liquid Flux}

To examine the effect of the volumetric liquid flux on the removal of zinc and nickel ions, electrochemical treatment was done at different volumetric liquid fluxes, ranging from $0.0092-0.0277 \mathrm{~m}^{3} \cdot \mathrm{m}^{-2} \cdot \mathrm{s}^{-1}$ in the laminar regime, corresponding to Reynolds number 717 to 2159 .

Figure 5.1 presents the percent zinc ions reduction after 48 hours of electrochemical treatment at different volumetric liquid fluxes, and at a constant $\mathrm{pH}$ of 5.5. It can be noted that the percent removal of zinc increased with a corresponding increase in the volumetric liquid flux. The percent removal of zinc increased from $70 \%$ at $0.0092 \mathrm{~m}^{3} . \mathrm{m}^{-}$ ${ }^{2} \cdot \mathrm{s}^{-1}$ to $80 \%$ at $0.0231 \mathrm{~m}^{3} \cdot \mathrm{m}^{-2} \cdot \mathrm{s}^{-1}$. The removal of zinc ions started decreasing at a volumetric liquid flux of $0.0277 \mathrm{~m}^{3} \cdot \mathrm{m}^{-2} \cdot \mathrm{s}^{-1}$

In the present study, the fractions of $\mathrm{Zn}^{++}$and $\mathrm{Ni}^{++}$remaining in the electrolyte were found to have a square-root relationship with time (Fig.5.2). The governing equation (Eq. 5.1) describing the reduction of $\mathrm{Zn}^{++}$and $\mathrm{Ni}^{++}$was extracted from an analogous model in which the diffusion of species from a stirred solution of limited volume varied as the square root of time [43]:

$$
\ln \left(\frac{C_{t}}{C_{o}}\right)=-k t^{1 / 2}
$$

where the ratio $\left(C_{1} / C_{o}\right)$ represents the fraction of metal ions remaining in the electrolyte, $C_{t}$ is the concentration of the metal ions at any given time $t, C_{0}$ is the initial concentration of the metal ions, and $k$ is the apparent rate constant. 
The log-natural plot of the fractional zinc ion concentration in the solution verses square root of treatment time is presented in Figure 5.2. The apparent rate constants are summarized in Table 5.1.

In the present study, the average mass transfer coefficients were obtained through concentration decay measurements of $\mathrm{Zn}^{++}$and $\mathrm{Ni}^{++}$. Sample calculations to determine average mass transfer coefficient and the uncertainties associated with it, both for nickel and zinc, are provided in the Appendix C. Mass transfer coefficients for $\mathrm{Zn}^{++}$are also reported in Table 5.1

Table 5.1: Apparent rate constants $(k) \&$ mass transfer coefficients $\left(k_{m}\right)$ for $\mathrm{Zn}^{++}$at different volumetric liquid fluxes

(Applied Voltage $=4.0 \mathrm{~V} ;$ Current $=46 \mathrm{~mA} ;$ Electrode surface area $=0.024 \mathrm{~m}^{2}$;

Temperature $=25^{\circ} \mathrm{C} ; \mathrm{pH}=5.5$ )

\begin{tabular}{|c|c|c|c|}
\hline $\begin{array}{c}\text { Flow rate } \\
\left(\mathrm{m}^{3} \cdot \mathrm{m}^{-2} \cdot \mathrm{s}^{-1}\right)\end{array}$ & $\begin{array}{c}\text { Removal } \\
(\%) \\
\text { Zinc }\end{array}$ & $\begin{array}{c}k \\
\left(\mathrm{~h}^{-1 / 2}\right) \\
\text { Zinc }\end{array}$ & $\begin{array}{c}k_{m} \\
\left(\mathrm{~m} \cdot \mathrm{h}^{-1}\right) \\
\text { Zinc }\end{array}$ \\
\hline 0.0092 & 70.0 & 0.159 & 0.051 \\
0.0138 & 71.0 & 0.167 & 0.053 \\
0.0185 & 78.0 & 0.189 & 0.064 \\
0.0231 & 80.0 & 0.212 & 0.069 \\
0.0277 & 72.0 & 0.174 & 0.055 \\
\hline
\end{tabular}

Figure 5.3 presents the percent removal of nickel ions. The percent removal of nickel ions increased from $28 \%$ at $0.0092 \mathrm{~m}^{3} \cdot \mathrm{m}^{-2} \cdot \mathrm{s}^{-1}$ to $34 \%$ at $0.0231 \mathrm{~m}^{3} \cdot \mathrm{m}^{-2} \cdot \mathrm{s}^{-1}$. Further increase in flow rate resulted in decrease in the removal of nickel ions, which was also observed in the case of zinc ion removal. Figure 5.4 shows the log-natural plot of the fractional nickel ion concentration verses square root of treatment time. The rate constants obtained from linear regression, and the mass transfer coefficients for $\mathrm{Ni}^{++}$, are presented in Table 5.2. 


\section{Table 5.2: Apparent rate constants $(k) \&$ mass transfer coefficients $\left(k_{m}\right)$ for $\mathrm{Ni}^{++}$at different volumetric liquid fluxes}

(Applied Voltage $=4.0 \mathrm{~V} ;$ Current $=46 \mathrm{~mA}$; Electrode surface area $=0.024 \mathrm{~m}^{2}$;

Temperature $=25^{\circ} \mathrm{C} ; \mathrm{pH}=5.5$ )

\begin{tabular}{|c|c|c|c|}
\hline $\begin{array}{c}\text { Flow rate } \\
\left(\mathrm{m}^{3} \cdot \mathrm{m}^{-2} \cdot \mathrm{s}^{-1)}\right.\end{array}$ & $\begin{array}{c}\text { Removal } \\
(\%) \\
\text { Nickel }\end{array}$ & $\begin{array}{c}k \\
\left(\mathrm{~h}^{-1 / 2}\right) \\
\text { Nickel }\end{array}$ & $\begin{array}{c}k_{m} \\
\left(\mathrm{~m}^{-1} \mathrm{~h}^{-1}\right) \\
\text { Nickel }\end{array}$ \\
\hline 0.0092 & 28.0 & 0.045 & 0.014 \\
0.0138 & 30.0 & 0.050 & 0.015 \\
0.0185 & 31.0 & 0.057 & 0.016 \\
0.0231 & 34.0 & 0.061 & 0.018 \\
0.0277 & 30.0 & 0.054 & 0.015 \\
\hline
\end{tabular}

Figure 5.5 shows the comparison of the percent reduction of zinc and nickel ions after 48 hours of treatment. Figure 5.6 presents the mass transfer coefficients of zinc and nickel ions. The mass transfer coefficients for nickel and zinc were found to have an exponential relationship with volumetric liquid flux; they increased with an increase in the volumetric liquid flux.

The zinc and nickel removal increased when volumetric liquid flux was increased from 0.0092 to $0.0231 \mathrm{~m}^{3} \cdot \mathrm{m}^{-2} \cdot \mathrm{s}^{-1}$. However, when the volumetric liquid flux was increased beyond $0.0231 \mathrm{~m}^{3} \cdot \mathrm{m}^{-2} \cdot \mathrm{s}^{-1}$, the removal of zinc and nickel was decreased. At volumetric flux of $0.0277 \mathrm{~m}^{3} \cdot \mathrm{m}^{-2} \cdot \mathrm{s}^{-1}$, the removal of zinc decreased from $80 \%$ to $72 \%$ and that of nickel from $34 \%$ to $30 \%$. This decrease in the removal of zinc and nickel may be attributed to the excessive agitation of the simulated wastewater, which resulted in bubbles formation at the surface of the cathode. These bubbles reduced the electroactive surface area of the cathode. Consequently, the metal ions deposition decreased.

Another observation that can be made (Figure 5.1 and 5.3) is that there was not much increase in the removal of zinc and nickel ions when the volumetric liquid flux was increased from 0.0092 to $0.0231 \mathrm{~m}^{3} \cdot \mathrm{m}^{-2} \cdot \mathrm{s}^{-1}$; the removal of zinc improved only by $10 \%$, while that of nickel by $6 \%$. According to the boundary layer theory, increase in the 
volumetric liquid flux reduces the diffusion layer at the surface of the cathode, and hence, the deposition of metal ions at the cathode surface increases. However, this trend was not observed in the present study. In case of dilute metal ion solutions, deposition could be mass transfer controlled or reaction controlled. Since an applied voltage of only $4.0 \mathrm{~V}$ was used in the present study, that might have resulted in low reaction kinetics of the process. Hence, no considerable increase in the removal of metal ions could be observed even at higher volumetric liquid fluxes.

Tables 5.1 and 5.2 indicate that the apparent rate constant for zinc and nickel reduction increased with an increase in volumetric liquid flux. The differences between minimum and maximum apparent rate constants were $33 \%$ and $35 \%$ for zinc and nickel, respectively.

The deposition of $\mathrm{Zn}^{++}$and $\mathrm{Ni}^{++}$on the surface of the flat plate cathode was visually observed after 48 hours of treatment. Most of the deposits were formed on that side of the cathode that directly faced the anode. On the back of the cathode, a very small deposition was observed. The deposits were light gray in color and appeared to be adhered as a fragmented sheet on the surface of the cathode.

From the discussion in the previous paragraphs, an anomaly can be found with respect to removal of nickel and zinc ions from the simulated wastewater. The standard reduction potential for $\mathrm{Ni}^{++}$is $-0.23 \mathrm{~V}$ (Eq. 2.5), which is higher than that of $-0.76 \mathrm{~V}$ for $\mathrm{Zn}^{++}$ (Eq.2.4). At the beginning of the present study, it was assumed that nickel ions would be removed more readily from the electrolyte than zinc ions. Nevertheless, when both nickel and zinc ions were present, the deposition of zinc ions increased. However, this is not a new phenomenon; in the literature, it has been frequently referred to as anomalous codeposition [27, 44-48].

A brief description of the anomalous co-deposition is provided as an aside in the following section. 
Figure 5.1: Effect of the volumetric liquid flux on the removal of $\mathrm{Zn}^{++}$. @ Temperature $=25^{\circ} \mathrm{C} ; \mathrm{pH}=5.5 ;$ Applied voltage $=4.0 \mathrm{~V}$; Current $=46 \mathrm{~mA}$.

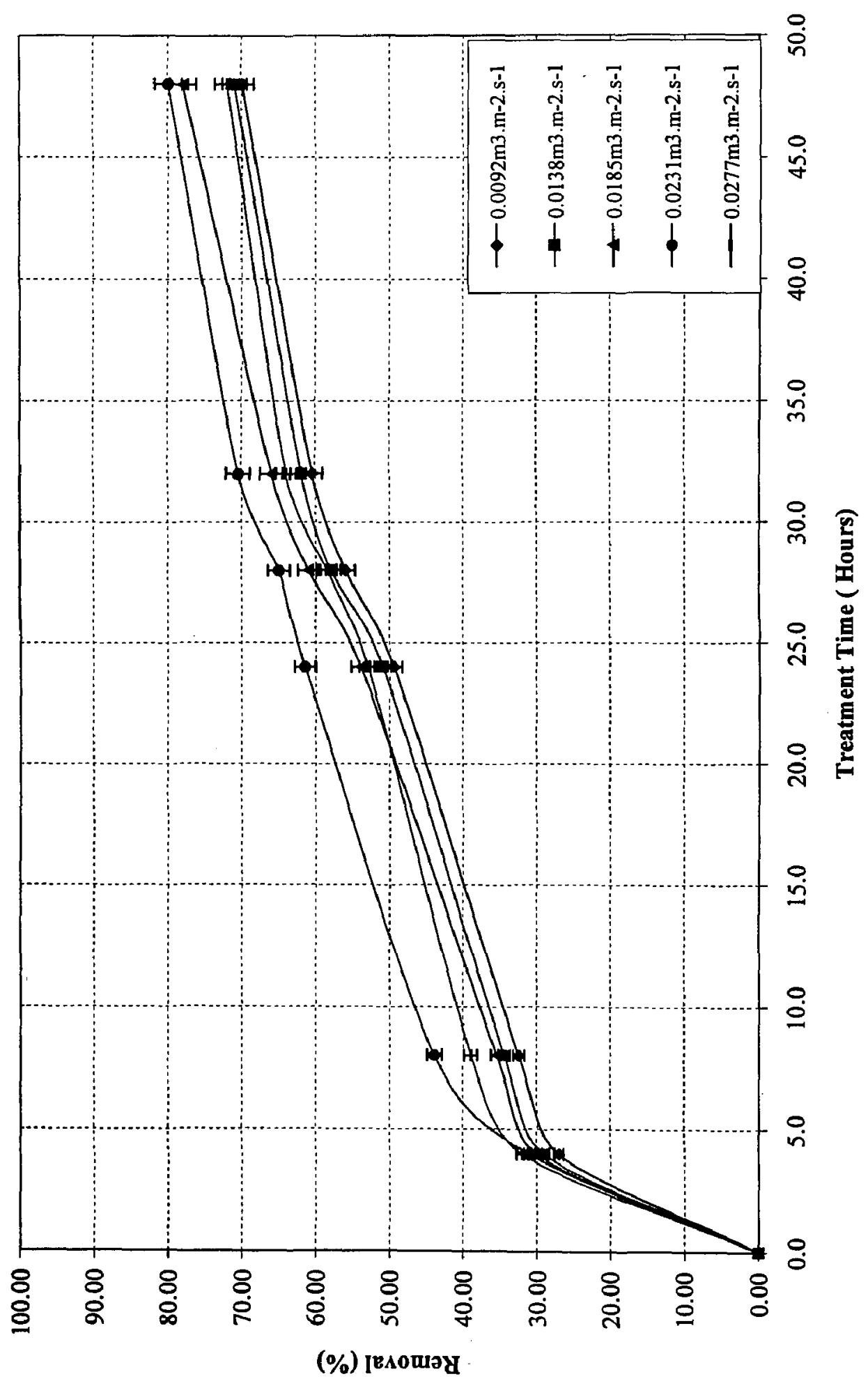


Figure 5.2: $\ln \left(\mathbf{C} / \mathbf{C}_{0}\right)$ verses $t^{1 / 2}$ for $\mathrm{Zn}^{++}$at different volumetric liquid flux.

@ Temperature $=25^{\circ} \mathrm{C} ; \mathrm{pH}=5.5 ;$ Applied voltage $=4.0 \mathrm{~V}$; Current $=46 \mathrm{~mA}$.

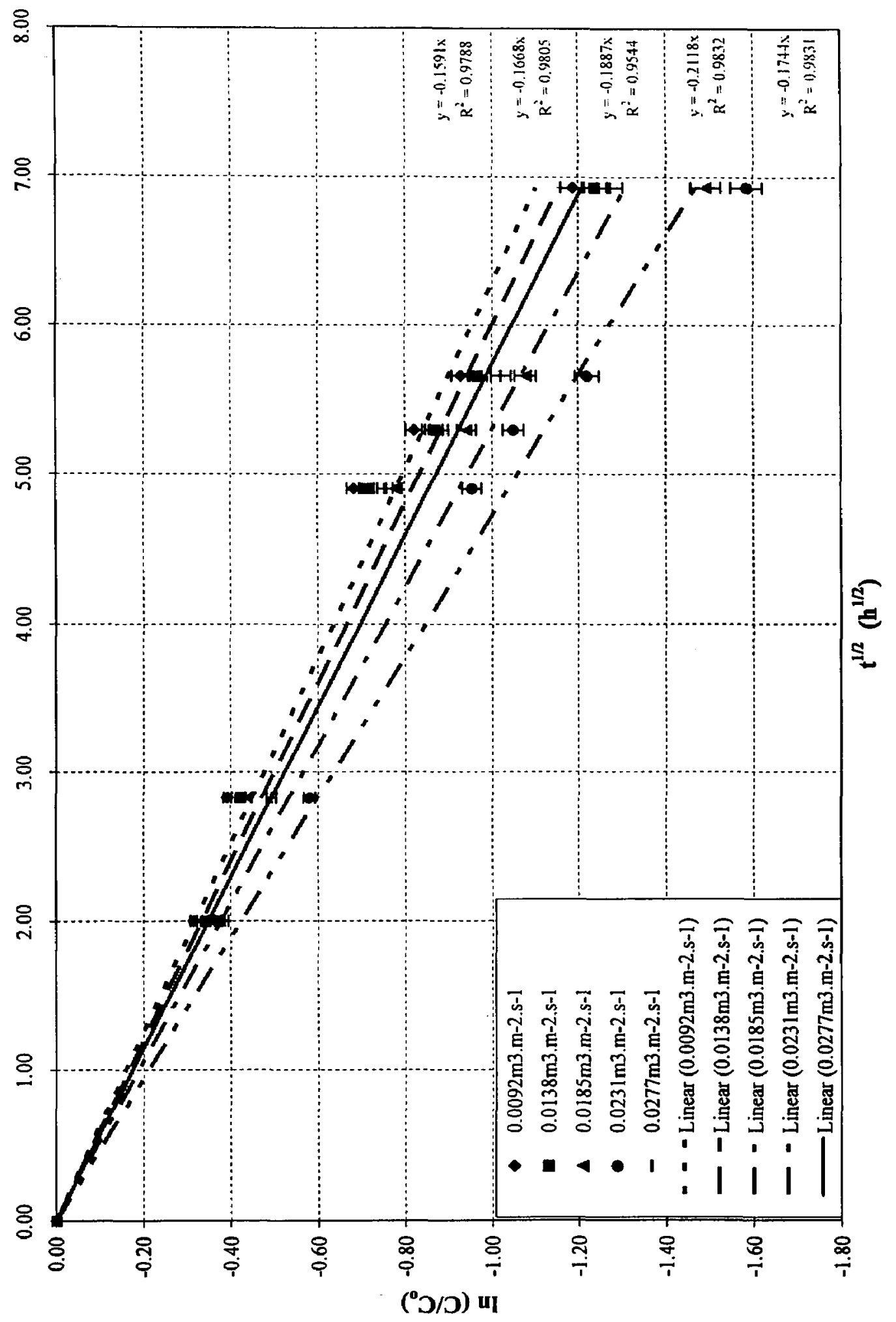


Figure 5.3: Effect of the volumetric liquid flux on the removal of $\mathrm{Ni}^{++}$.

@ Temperature $=25^{\circ} \mathrm{C} ; \mathrm{pH}=5.5$; Applied voltage $=4.0 \mathrm{~V}$; Current $=46 \mathrm{~mA}$.

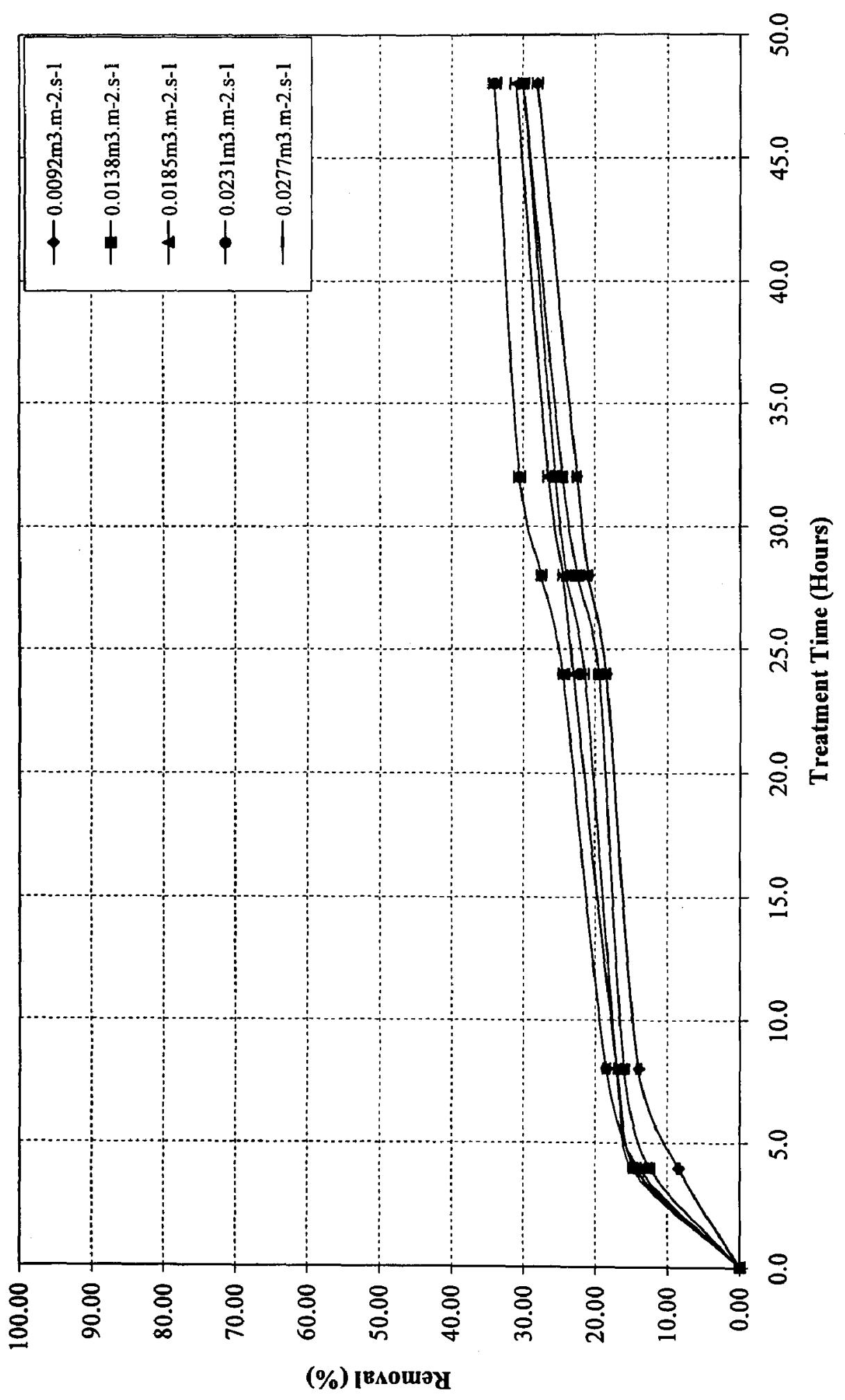


Figure 5.4: $\ln \left(\mathrm{C} / \mathrm{C}_{\mathbf{0}}\right)$ verses $\mathrm{t}^{1 / 2}$ for $\mathrm{Ni}^{++}$at different volumetric liquid flux.

(a) Temperature $=25^{\circ} \mathrm{C} ; \mathrm{pH}=5.5$; Applied voltage $=4.0 \mathrm{~V}$; Current $=46 \mathrm{~mA}$.

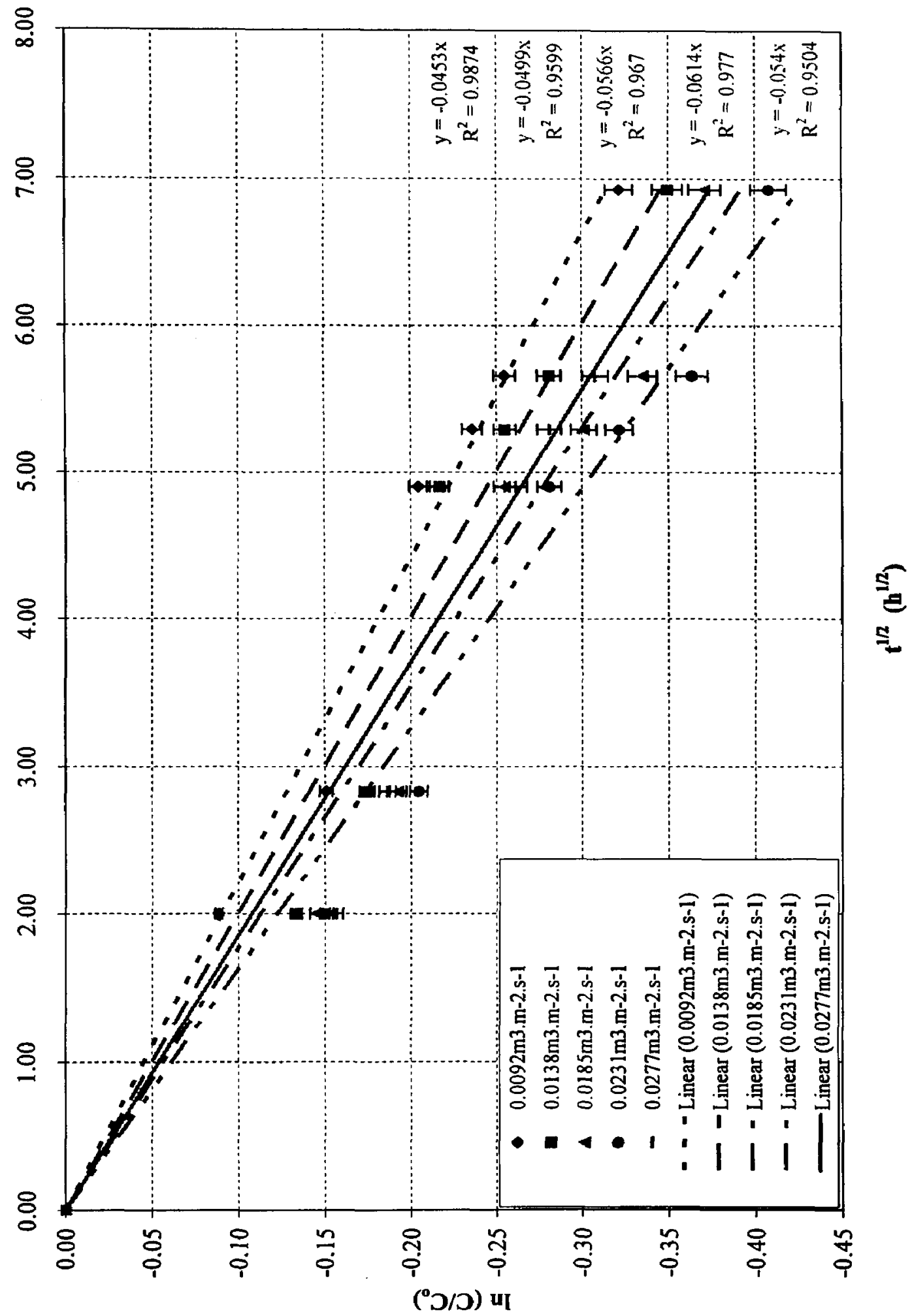


Figure 5.5: Comparison of the percent reduction of $\mathrm{Zn}^{++} \& \mathrm{Ni}^{++}$at different volumetric liquid flux.

@ Temperature $=25^{\circ} \mathrm{C} ; \mathrm{pH}=5.5 ;$ Applied voltage $=4.0 \mathrm{~V} ;$ Current $=46 \mathrm{~mA}$.

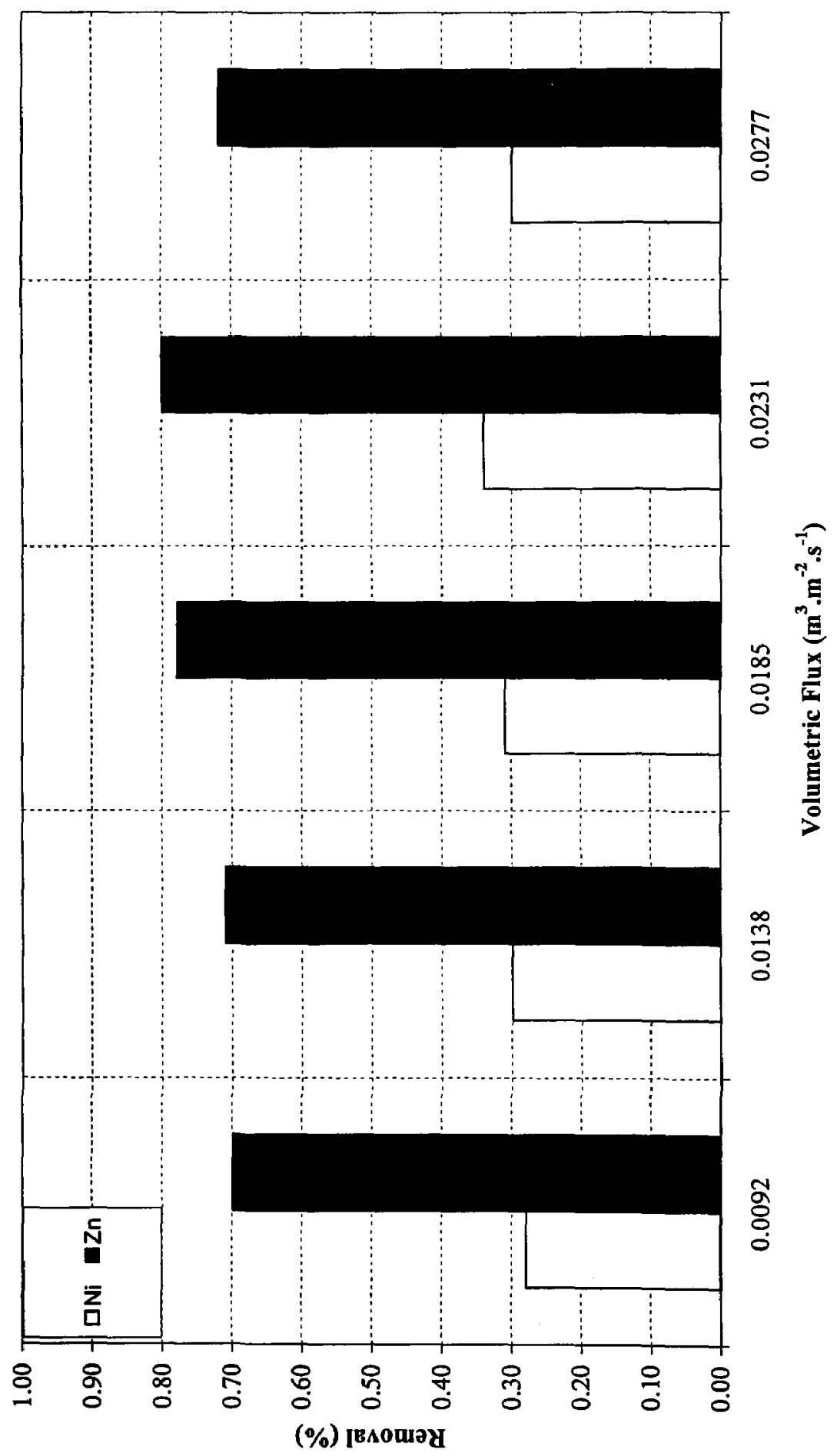


Figure 5.6: Comparison of mass transfer coefficient of $\mathrm{Zn}^{++} \& \mathrm{Ni}^{++}$at different volumetric liquid flux.

( Temperature $=25^{\circ} \mathrm{C} ; \mathrm{pH}=5.5 ;$ Applied voltage $=4.0 \mathrm{~V} ;$ Current $=46 \mathrm{~mA}$.

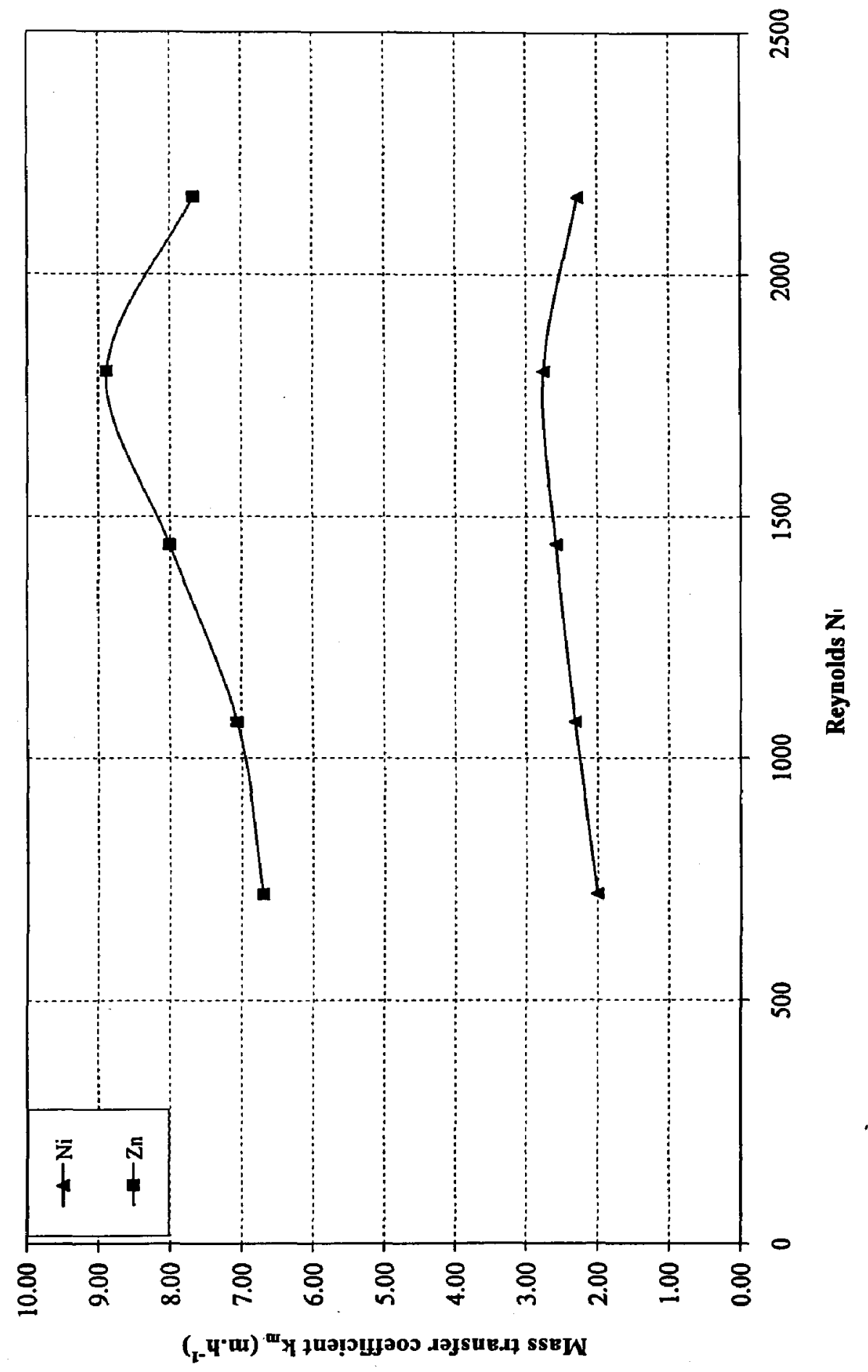




\subsubsection{Anomalous co-deposition}

Anomalous co-deposition refers to a phenomenon that occurs during the electrodeposition of two or more metals, in which the less noble metal is preferentially deposited instead of the more noble metal [27]. Zinc-nickel system forms a typical example of anomalous co-deposition.

Dahms and croll [44] investigated anomalous co-deposition of nickel-iron alloys. They demonstrated that the suppression of nickel deposition occurred when the rate of hydrogen evolution exceeded the diffusion-limited current due to hydrogen ions resulting in the formation of metallic hydroxides. In their study, it was believed that the formation of ferrous hydroxide blocked nickel discharge while iron was discharged readily from this layer. They had developed a model in which they had shown that the electrode surface $\mathrm{pH}$ could rise to as much as 9 for an iron-nickel system having a bulk liquid $\mathrm{pH}$ of 2.5. Since this theory was first introduced, others have substantiated the hydroxide suppression of the more-noble metal for zinc-cobalt and zinc-nickel system [45].

The hypothesis of Dahms and Croll [44], however, failed to explain some phenomena during anomalous co-deposition such as, the lack of hydrogen reduction or the increase in nickel content in the alloy with an increase in $\mathrm{pH}$ [46]. These mechanisms include adsorbed intermediates that act as catalyst in the deposition of the less-noble metal. Studies include zinc-nickel system from a chloride medium [47] or from a sulfate medium $[46,48]$.

Miranda et al. [46] have shown that anomalous co-deposition occurs without permanent surface alkalination. It was observed that at a bulk $\mathrm{pH}$ of 3.0 , the surface $\mathrm{pH}$ of the cathode was nearly potential independent and remained close to the bulk $\mathrm{pH}$. One of the drawbacks to the theory developed by Dahms and Croll [44] was that it was based on a derived model in which they were able to calculate the surface concentration of hydrogen ions from other measurable quantities. The $\mathrm{pH}$ corresponding to this calculated hydrogen ion concentration may be greater than that actually encountered in practice. Nevertheless, the results of researchers who have measured surface $\mathrm{pH}$ for anomalous 
co-deposition have identified that an increase does occur. Therefore, the theory proposed by Dahms and Croll [44] provide a reasonable explanation for the anomalous codeposition observed in the present study. 


\subsection{Effect of Electrode Surface Area}

The effect of the electrode surface area on the reduction of zinc and nickel ions was investigated for 48 hours using flat plate electrodes. These experiments were performed at a volumetric flux of $0.0231 \mathrm{~m}^{3} \cdot \mathrm{m}^{-2} \cdot \mathrm{s}^{-1}$ and a $\mathrm{pH}$ of 5.5 . Two different aluminum cathodes, one having surface area of $0.024 \mathrm{~m}^{2}$ (one anode and one cathode) and the other of $0.048 \mathrm{~m}^{2}$ (two anodes and two cathodes) were used. Figure 5.7 shows that the removal of zinc was higher at the cathode having larger surface area $\left(0.048 \mathrm{~m}^{2}\right)$. The removal of zinc increased from $80 \%$ at the cathode with smaller surface area $\left(0.024 \mathrm{~m}^{2}\right)$ to $94 \%$ at the cathode having larger surface area $\left(0.048 \mathrm{~m}^{2}\right)$. The log-natural plot of the fractional zinc ion concentration in the solution verse square root of treatment time is presented in Figure 5.8.

Figure 5.9 compares the percent reduction of nickel ions in the simulated wastewater using the two different surface area cathodes. A similar trend was observed in case of nickel ions. The reduction of nickel ions increased with an increase in the surface area of the cathode. A $46 \%$ reduction with the larger surface area cathode and $36 \%$ reduction with the smaller surface area cathode were achieved. The log-natural plot of fractional nickel ion concentration in the solution verses square root of treatment time is presented in Figure 5.10. Figure 5.11 presents the comparison of the percent removal of zinc and nickel ions at different electrode surface areas. The apparent rate constants and mass transfer coefficients are summarized in Table 5.3.

Table 5.3: Apparent rate constants $(k) \&$ mass transfer coefficients $\left(k_{m}\right)$ for $\mathrm{Zn}^{++} \&$ $\mathrm{Ni}^{++}$at different electrode surface area.

(Applied Voltage $=4.0 \mathrm{~V} ; \mathrm{pH}=5.5 ;$ Volumetric liquid flux $=0.0234 \mathrm{~m}^{3} \cdot \mathrm{m}^{-2} \cdot \mathrm{s}^{-1}$; Temperature $=25^{\circ} \mathrm{C}$; Current $=46 \mathrm{~mA}$ )

\begin{tabular}{|c|c|c|c|c|}
\hline $\begin{array}{c}\text { Ionic } \\
\text { Species }\end{array}$ & $\begin{array}{c}\text { Surface } \\
\text { area } \\
\mathrm{m}^{2}\end{array}$ & $\begin{array}{c}\text { Removal } \\
(\%)\end{array}$ & $\begin{array}{c}k \\
\left(\mathrm{~h}^{-1 / 2}\right)\end{array}$ & $\begin{array}{c}k_{m} \\
\left(\mathrm{~m}_{\mathrm{h}}^{-1}\right)\end{array}$ \\
\hline Zinc & 0.024 & 80.0 & 0.212 & 0.069 \\
& 0.048 & 94.0 & 0.384 & 0.059 \\
\hline Nickel & 0.024 & 34.0 & 0.061 & 0.018 \\
& 0.048 & 46.0 & 0.085 & 0.013 \\
\hline
\end{tabular}


Figure 5.7: Effect of the electrode surface area on the removal of $\mathrm{Zn}^{++}$.

(a) Temperature $=25^{\circ} \mathrm{C} ;$ Volumetric liquid flux $=0.0231 \mathrm{~m}^{3} \cdot \mathrm{m}^{-2} \cdot \mathrm{s}^{-1} ; \mathrm{pH}=5.5$; Applied voltage $=4.0 \mathrm{~V} ;$ Current $=46 \mathrm{~mA}$.

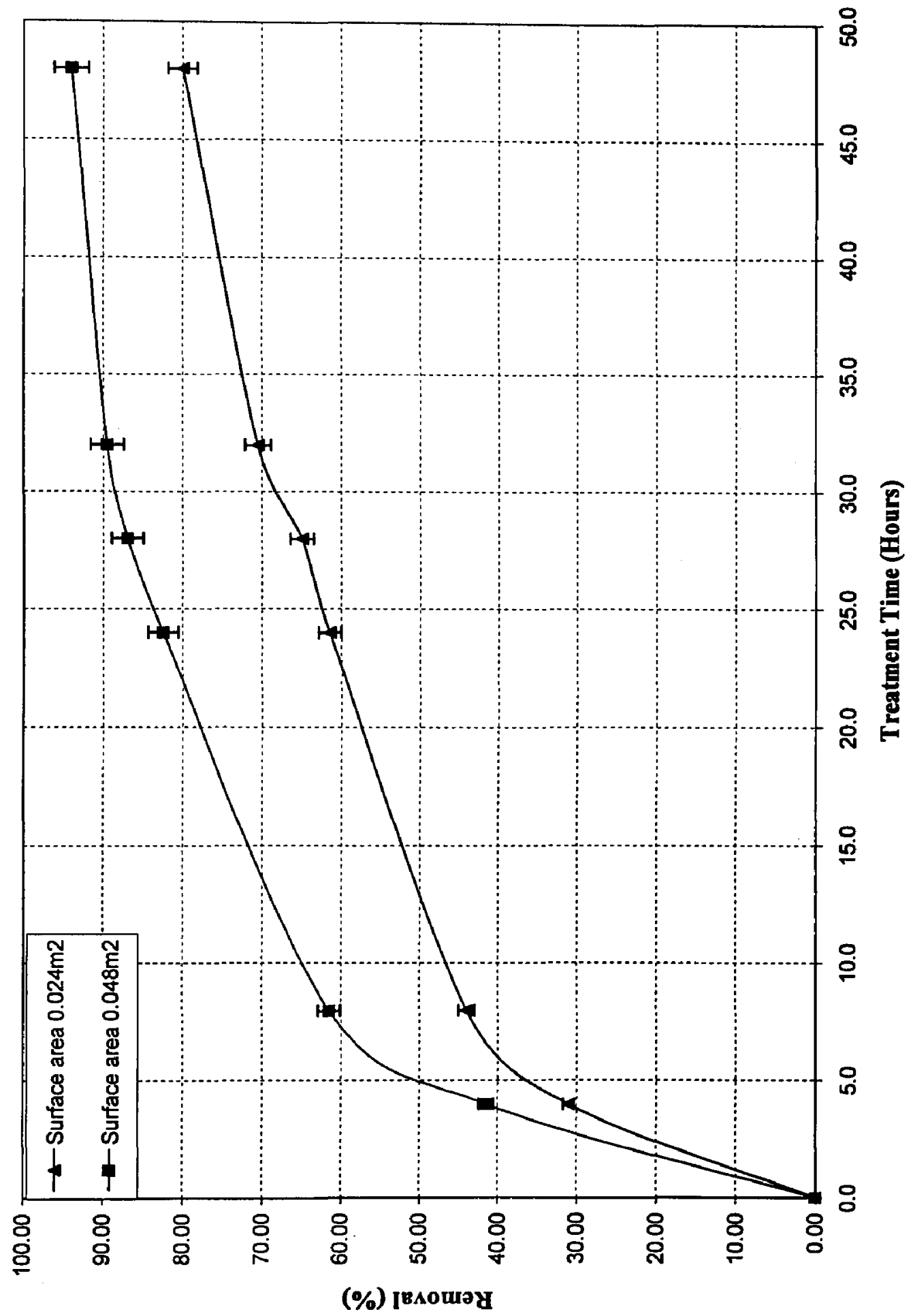


Figure 5.8: $\ln \left(C / C_{0}\right)$ verses $t^{1 / 2}$ for $\mathrm{Zn}^{++}$at different electrode surface area.

@ Temperature $=25^{\circ} \mathrm{C}$; Volumetric liquid flux $0.0231 \mathrm{~m}^{3} \cdot \mathrm{m}^{-2} \cdot \mathrm{s}^{-1} ; \mathrm{pH}=5.5$;

Applied voltage $=4.0 \mathrm{~V} ;$ Current $=46 \mathrm{~mA}$.

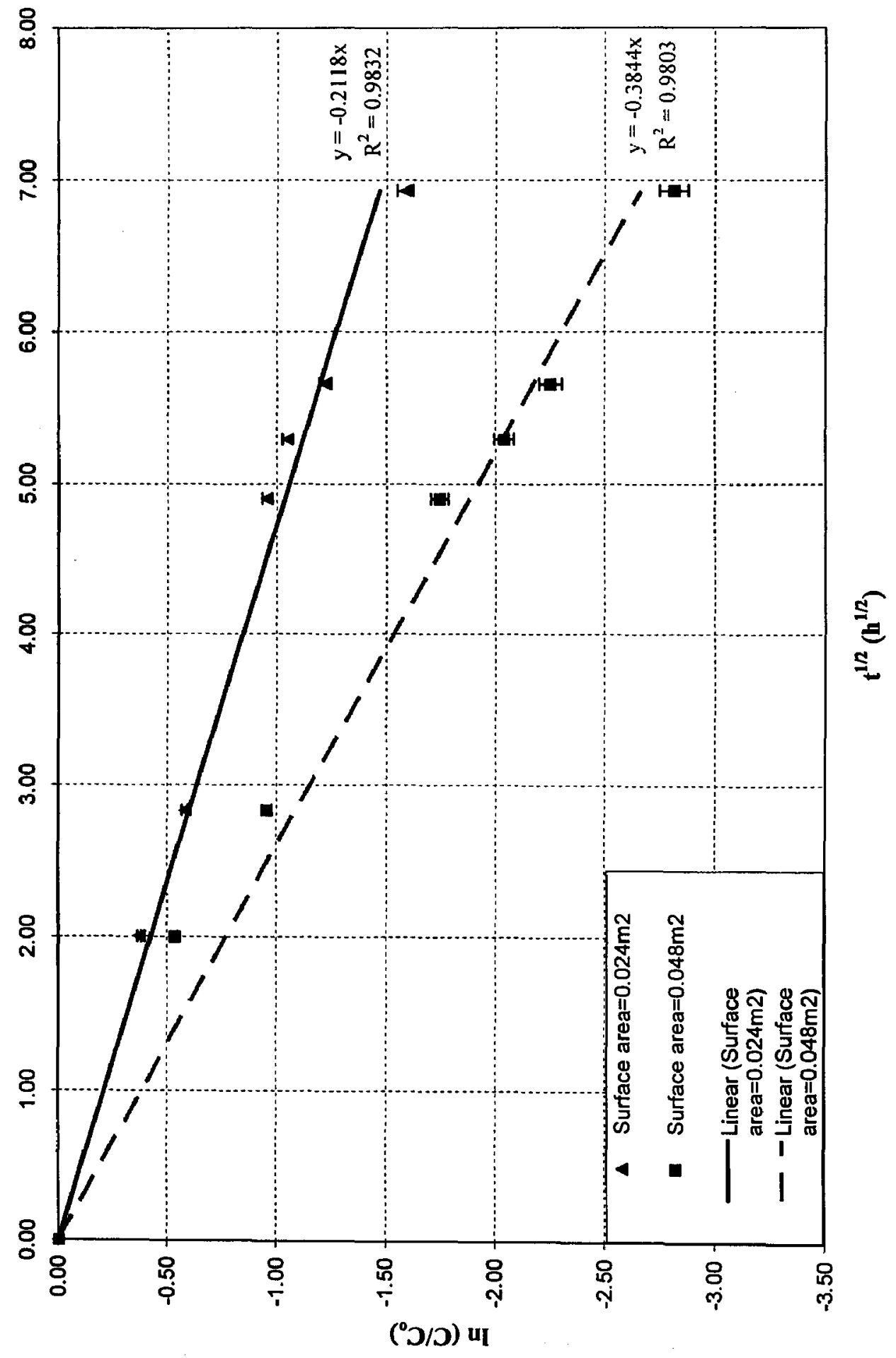


Figure 5.9: Effect of the electrode surface area on the removal of $\mathrm{Ni}^{++}$.

(a) Temperature $=25^{\circ} \mathrm{C}$; Volumetric liquid flux $=0.0231 \mathrm{~m}^{3} \cdot \mathrm{m}^{-2} \cdot \mathrm{s}^{-1} ; \mathrm{pH}=5.5$; Applied voltage $=4.0 \mathrm{~V} ;$ Current $=46 \mathrm{~mA}$.

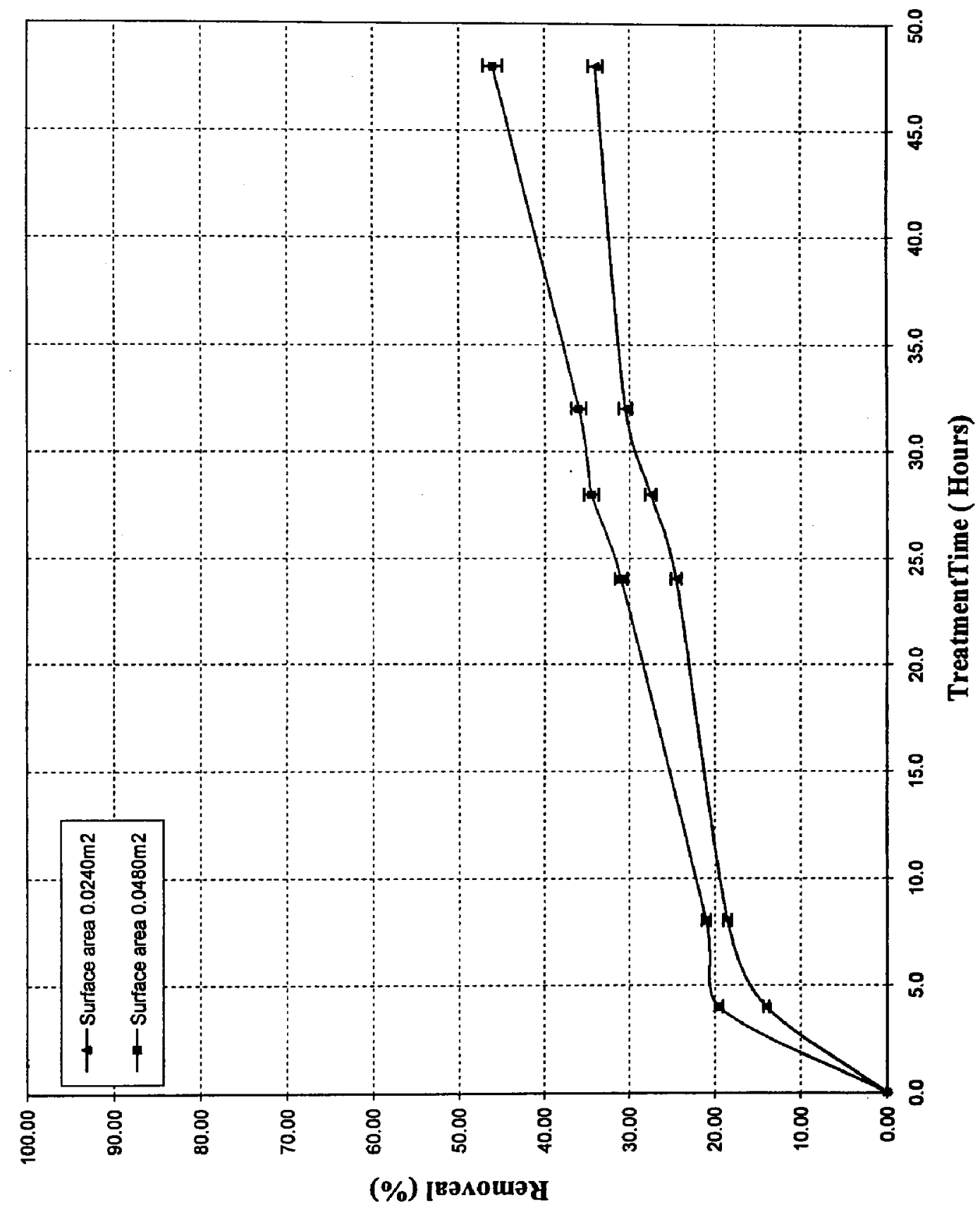


Figure 5.10: $\ln \left(C / C_{0}\right)$ verses $\mathrm{t}^{1 / 2}$ for $\mathrm{Ni}^{++}$at different electrode surface area.

@ Temperature $=25^{\circ} \mathrm{C} ;$ Volumetric Liquid flux $0.0231 \mathrm{~m}^{3} \cdot \mathrm{m}^{-2} \cdot \mathrm{s}^{-1} ; \mathrm{pH}=5.5$; Applied voltage $=4.0 \mathrm{~V}$; Current $=46 \mathrm{~mA}$.

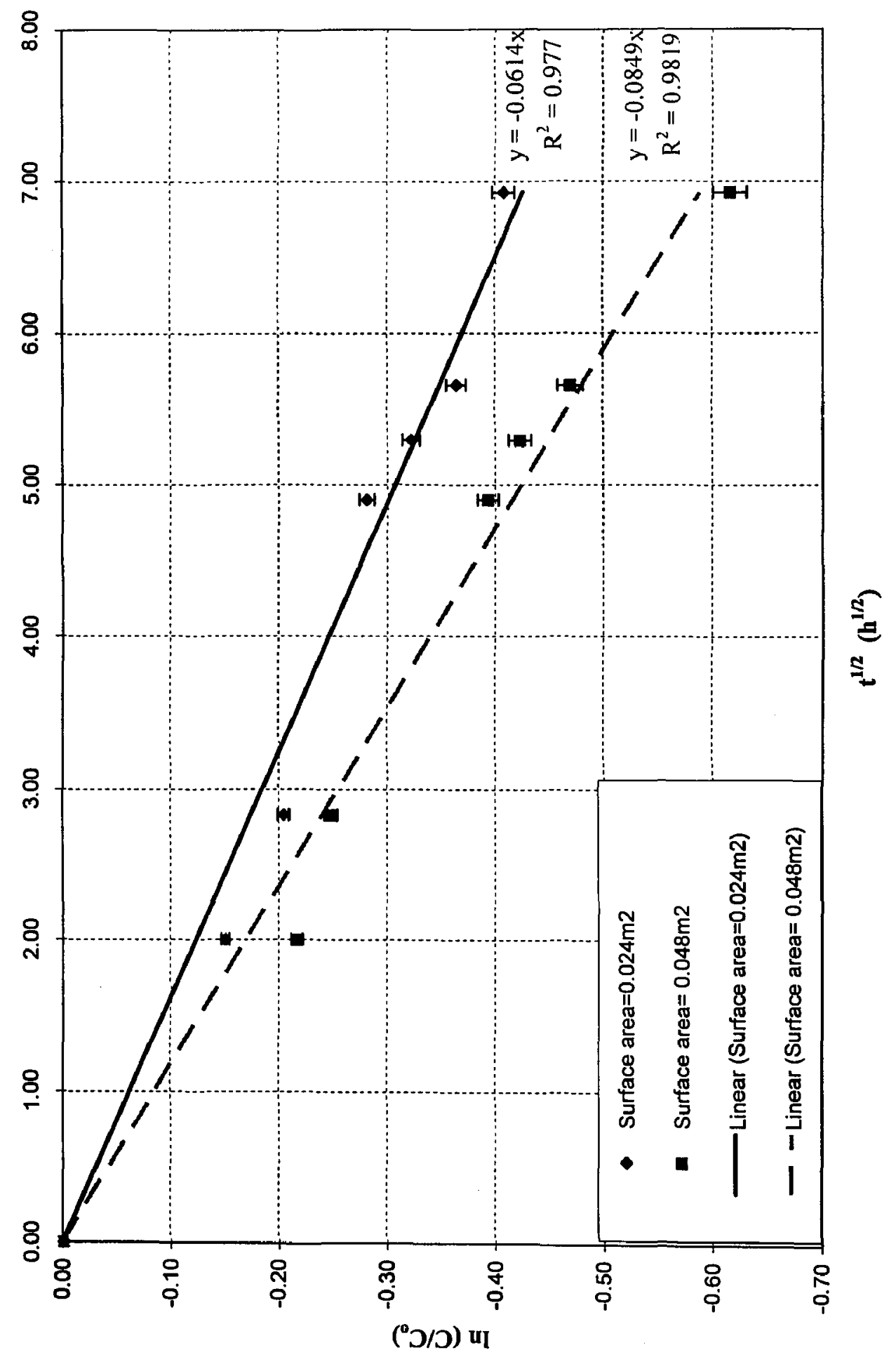


Figure 5.11: Comparison of the removal of $\mathrm{Zn}^{++} \& \mathrm{Ni}^{++}$at different electrode surface area.

(a) Temperature $=25^{\circ} \mathrm{C}$; Volumetric liquid flux $=0.0231 \mathrm{~m}^{3} \cdot \mathrm{m}^{-2} \cdot \mathrm{s}^{-1} ; \mathrm{pH}=5.5$; Applied voltage $=4.0 \mathrm{~V}$; Current $=46 \mathrm{~mA}$.

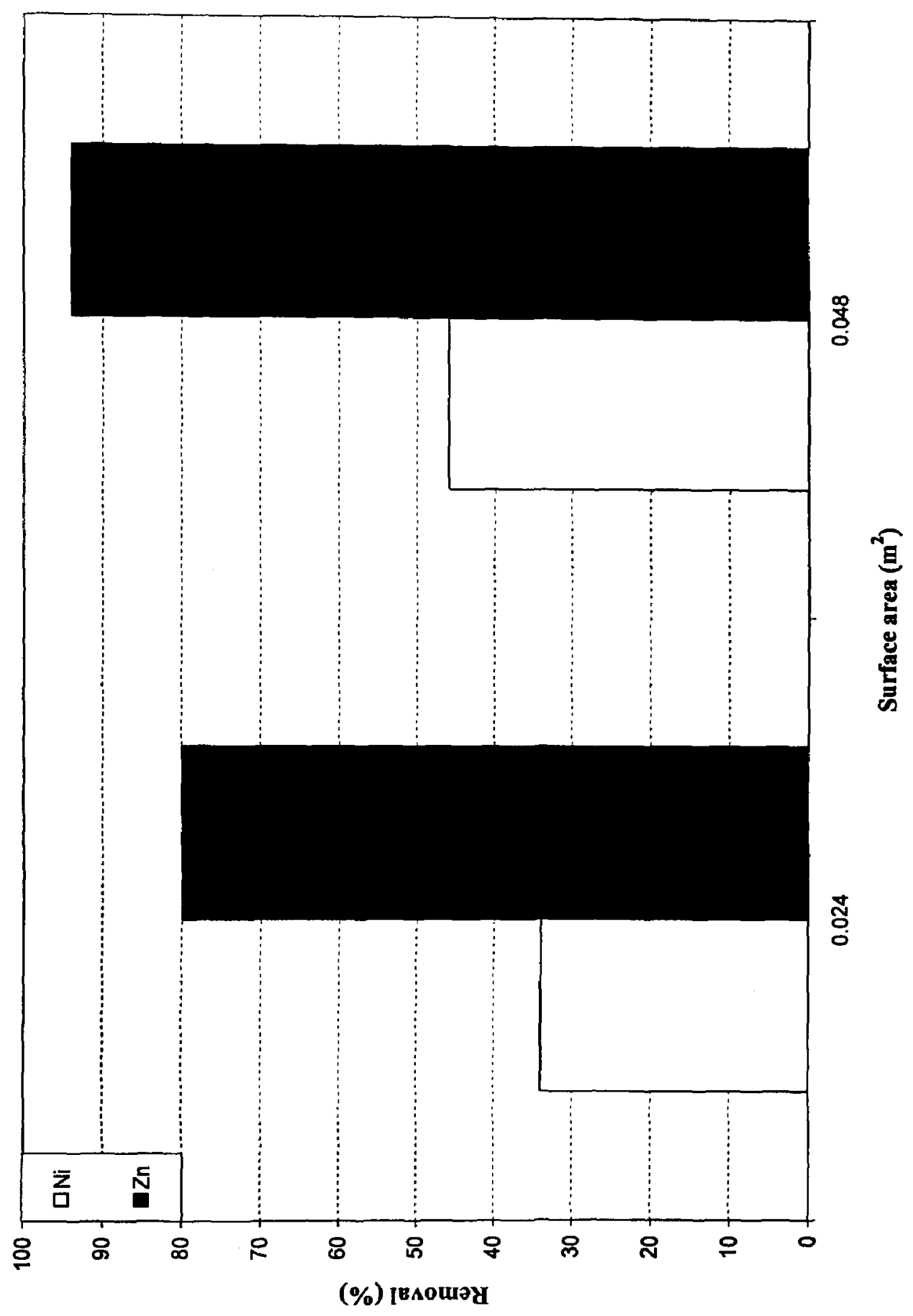


Examination of this table reveals that the apparent rate constants for zinc and nickel increased by $14 \%$ and $12 \%$, respectively, when the surface area of the electrode was doubled. On the other hand, the mass transfer coefficients for zinc and nickel decreased by $14 \%$ and $40 \%$, respectively, when the surface area of the electrode was doubled. Mass transfer coefficient depends on volumetric liquid flux. In the banging of the study, it was found that at the high Reynolds number (2159 at volumetric liquid flux of $0.0277 \mathrm{~m}^{3} \cdot \mathrm{m}^{-}$ $\left.{ }^{2} \cdot s^{-1}\right)$ the mass transfer coefficients for nickel and zinc decreased. In this case, when the surface areas of the electrode was doubled (two cathodes plates used), the hydraulic diameter of the flow channels increased, and hence the Reynolds number increased to a value of 2542 at a volumetric liquid flux of $0.0231 \mathrm{~m}^{3} \cdot \mathrm{m}^{-2} \cdot \mathrm{s}^{-1}$. This high value of Reynolds number provides the reasonable explanation for the lower values of mass transfer coefficients for zinc and nickel ions. The observed deposit on the cathode was similar to that found previously at different flow rates. 


\subsection{Effect of pH}

Before discussing the results, a brief description of the behavior of $\mathrm{pH}$ in the electrochemical cell is provided below.

In this study, the bulk $\mathrm{pH}$ decreased during first 8 hours of treatment in all the experimental runs and $1.0 \mathrm{M} \mathrm{KOH}$ solution was added to control the $\mathrm{pH}$. After that, the $\mathrm{pH}$ was stable up to 42 hours of treatment. In the last 6 hours, the $\mathrm{pH}$ slightly increased.

The decrease in the bulk electrolyte $\mathrm{pH}$ was believed to have occurred from the electrolysis of water at the anode. Brenner et al [27] also observed a decrease in the bulk $\mathrm{pH}$ due to electrolysis of water. For electrolysis of water under neutral and acidic solutions the reaction at the anode is [26]:

$$
\mathrm{H}_{2} \mathrm{O} \rightarrow 2 \mathrm{H}^{+}+\frac{1}{2} \mathrm{O}_{2}+2 e^{-} \quad E^{o}=+1.23 \mathrm{~V}
$$

Besides the basic metal deposition reactions (eqs. 2.4 and 2.5), other reactions also occur in the electrochemical cell, such as the decomposition of water, reduction of oxygen and the evolution of hydrogen gas. Hydrogen evolution, oxygen reduction and water decomposition reactions tend to increase $\mathrm{pH}$ at the cathode surface by either $\mathrm{H}^{+}$ions consumption or $\mathrm{OH}^{-}$ions generation [26].

$$
\begin{array}{ll}
2 \mathrm{H}_{2} \mathrm{O}+2 e^{-} \rightarrow \mathrm{H}_{2}+2 \mathrm{OH}^{-} & E^{o}=-0.83 \mathrm{~V} \\
\mathrm{O}_{2}+4 \mathrm{H}^{+}+4 e^{-} \rightarrow 2 \mathrm{H}_{2} \mathrm{O} & E^{o}=+1.23 \mathrm{~V} \\
2 \mathrm{H}^{+}+2 e^{-} \rightarrow \mathrm{H}_{2} & E^{o}=0.00 \mathrm{~V}
\end{array}
$$

Figure 5.12 presents the effect of $\mathrm{pH}$ on the reduction of zinc ions at the volumetric liquid flux of $0.0231 \mathrm{~m}^{3} \cdot \mathrm{m}^{2} \cdot \mathrm{s}^{-1}$ in the laminar region; it shows that when the $\mathrm{pH}$ of the electrochemical cell was increased, the removal of $\mathrm{Zn}^{++}$increased as well. The effect of 
pH became prominent after 8 hours of electrochemical treatment; the percent removal of $\mathrm{Zn}^{++}$increased from $13 \%$ at a pH of 3.5 to $85 \%$ at a pH of 6.5 , and after 48 hours of electrochemical treatment, the final removal of zinc ions increased from $21 \%$ at a $\mathrm{pH}$ of 3.5 to $97 \%$ at a $\mathrm{pH}$ of 6.5 .

Figure 5.13 presents a log-natural plot of fractional zinc ions concentration versus square root of time; apparent rate constants for $\mathrm{Zn}^{++}$, which were obtained from the slopes of the corresponding regression lines, are reported in Table 5.4.

Table 5.4: Apparent rate constants $(k) \&$ mass transfer coefficients $\left(k_{m}\right)$ for $\mathrm{Zn}^{++}$at different $\mathrm{pH}$

(Applied Voltage $=4.0 \mathrm{~V} ;$ Current $=46 \mathrm{~mA} ;$ Electrode surface area $=0.024 \mathrm{~m}^{2} ;$ Volumetric liquid flux $=0.0231 \mathrm{~m}^{3} \cdot \mathrm{m}^{-2} \cdot \mathrm{s}^{-1}$; Temperature $=25^{\circ} \mathrm{C}$ )

\begin{tabular}{|c|c|c|c|}
\hline $\mathrm{pH}$ & $\begin{array}{c}\text { Removal } \\
(\%) \\
\text { Zinc }\end{array}$ & $\begin{array}{c}k \\
\left(\mathrm{~h}^{-1 / 2}\right) \\
\text { Zinc }\end{array}$ & $\begin{array}{c}k_{m} \\
\left(\mathrm{~m}^{-1} \mathrm{~h}^{-1}\right) \\
\text { Zinc }\end{array}$ \\
\hline 3.5 & 21.0 & 0.036 & 0.010 \\
4.5 & 54.0 & 0.105 & 0.033 \\
5.5 & 80.0 & 0.212 & 0.068 \\
6.5 & 97.0 & 0.548 & 0.143 \\
\hline
\end{tabular}

The results for nickel ions removal are presented in Figure 5.14. A similar trend was found as in the case of $\mathrm{Zn}^{++}$removal, the percent removal of $\mathrm{Ni}^{++}$increased with an increase in the $\mathrm{pH}$. After 48 hours of electrochemical treatment, the percent removal of nickel ions increased from $16 \%$ at a pH of 3.5 to $62 \%$ at a pH of 6.5 .

Figure 5.15 shows a log-natural plot of fractional nickel ions concentration versus square root of treatment time; a summary of apparent rate constants is presented in Table 5.5. Figure 5.16 presents the comparison of percent removal of zinc and nickel ions at different $\mathrm{pH}$. 
Table 5.5: Apparent rate constants $(k) \&$ mass transfer coefficients $(\mathrm{km})$ for $\mathrm{Ni}^{++}$at different $\mathrm{pH}$

(Applied Voltage $=4.0 \mathrm{~V} ;$ Current $=46 \mathrm{~mA}$; Electrode surface area $=0.024 \mathrm{~m}^{2}$; Volumetric liquid flux $=0.0231 \mathrm{~m}^{3} \cdot \mathrm{m}^{-2} \cdot \mathrm{s}^{-1}$; Temperature $=25^{\circ} \mathrm{C}$ )

\begin{tabular}{|c|c|c|c|}
\hline $\mathrm{pH}$ & $\begin{array}{c}\text { Removal } \\
(\%)\end{array}$ & $\begin{array}{c}k \\
\left(\mathrm{~h}^{-1 / 2}\right)\end{array}$ & $\begin{array}{c}k_{m} \\
\left(\mathrm{~m} \cdot \mathrm{h}^{-1}\right)\end{array}$ \\
& Nickel & Nickel & Nickel \\
\hline 3.5 & 16.0 & 0.027 & 0.007 \\
4.5 & 25.0 & 0.041 & 0.012 \\
5.5 & 34.0 & 0.061 & 0.018 \\
6.5 & 62.0 & 0.148 & 0.042 \\
\hline
\end{tabular}

The apparent rate constants for zinc and nickel ions increased with an increase in the $\mathrm{pH}$. At a $\mathrm{pH}$ of 6.5, the apparent rate constants for nickel and zinc are almost 6 times higher than at a $\mathrm{pH}$ of 3.5. Likewise, the mass transfer coefficients also increased with an increase in the $\mathrm{pH}$; these are 5 times higher at a $\mathrm{pH}$ of 6.5 than at a $\mathrm{pH}$ of 3.5.

Assuming that the hypothesis proposed by Dahms and Croll [44] was actually true in the present study, an increase in the concentration of $\mathrm{Zn}^{+2}$ ions in the cathode layer caused an increase in the rate of $\mathrm{Zn}(\mathrm{OH})_{2}$ formation retarded the rate of nickel ion discharge. The trend of the variation of the metal removal with the $\mathrm{pH}$ is similar to observations reported in the literature $[27,45-48]$.

From the discussion of the previous paragraphs may be observed that the highest removal of both zinc and nickel ions was achieved at a solution $\mathrm{pH}$ of 6.5 . At this $\mathrm{pH}$, a negligible amount $\left(0.035 \mathrm{mg} \cdot 1^{-1}\right)$ of nickel precipitated as nickel hydroxide. Further increase in the pH could have lead to even more excessive precipitation of nickel. Doan et al [17] also found the same trend. They found the increasing trend in the rate constant and the mass transfer coefficient with an increase in $\mathrm{pH}$. 
Figure 5.12: Effect of $\mathrm{pH}$ on the removal of $\mathrm{Zn}^{++}$.

(a) Volumetric liquid flux $=0.0231 \mathrm{~m}^{3} \cdot \mathrm{m}^{-2} \cdot \mathrm{s}^{-1} ;$ Temperature $=25^{\circ} \mathrm{C}$; Applied Voltage $=4.0 \mathrm{~V}$; Current $=46 \mathrm{~mA}$.

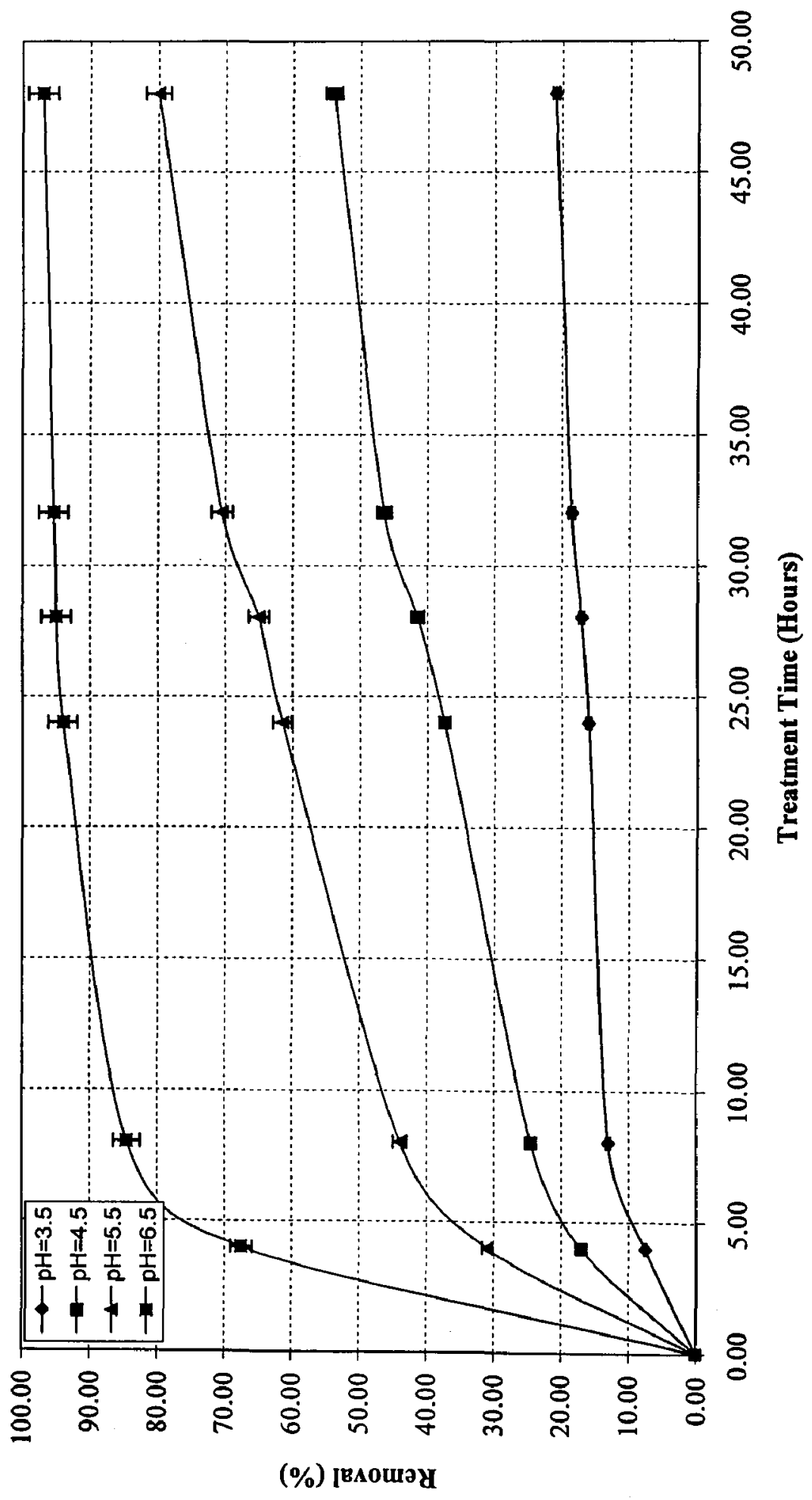


Figure 5.13: $\ln \left(\mathrm{C} / \mathrm{C}_{0}\right)$ verses $\mathrm{t}^{1 / 2}$ for $\mathrm{Zn}^{++}$at different $\mathrm{pH}$.

(a) Volumetric liquid flux $=0.0231 \mathrm{~m}^{3} \cdot \mathrm{m}^{-2} \cdot \mathrm{s}^{-1}$; Temperature $=25^{\circ} \mathrm{C}$; Applied Voltage $=4.0 \mathrm{~V}$; Current $=46 \mathrm{~mA}$.

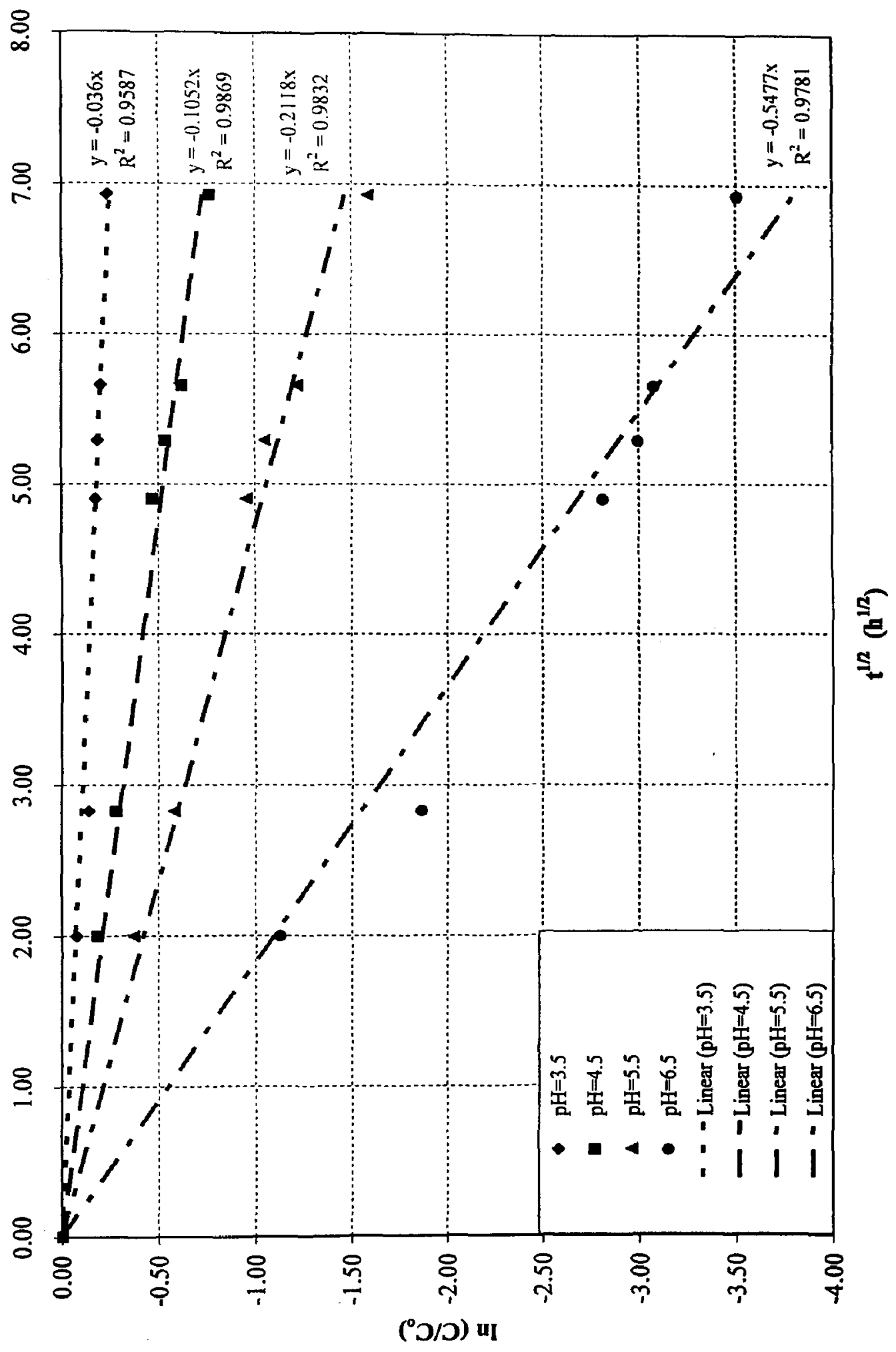


Figure 5.14: Effect of $\mathrm{pH}$ on removal of $\mathrm{Ni}^{++}$.

(a) Volumetric liquid flux $=0.0231 \mathrm{~m}^{3} \cdot \mathrm{m}^{-2} \cdot \mathrm{s}^{-1} ;$ Temperature $=25^{\circ} \mathrm{C}$; Applied voltage $=4.0 \mathrm{~V}$; Current $=46 \mathrm{~mA}$.

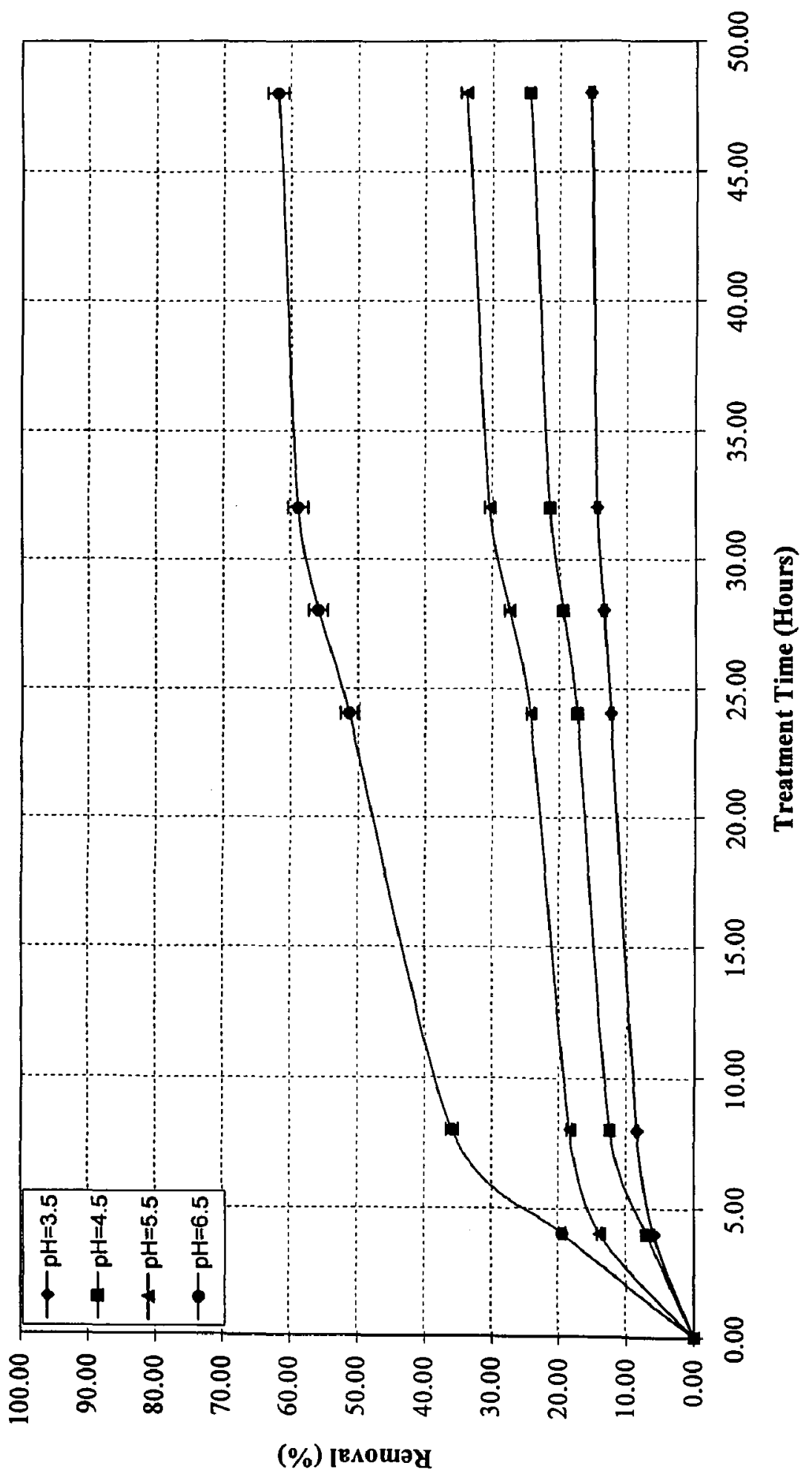


Figure 5.15: In $\left(\mathrm{C} / \mathrm{C}_{0}\right)$ verses $\mathrm{t}^{1 / 2}$ for $\mathrm{Ni}^{++}$at different $\mathrm{pH}$.

(a) Volumetric liquid flux $=0.0231 \mathrm{~m}^{3} \cdot \mathrm{m}^{-2} \cdot \mathrm{s}^{-1}$; Temperature $=25^{\circ} \mathrm{C}$; Applied voltage $=4.0 \mathrm{~V} ;$ Current $=46 \mathrm{~mA}$.

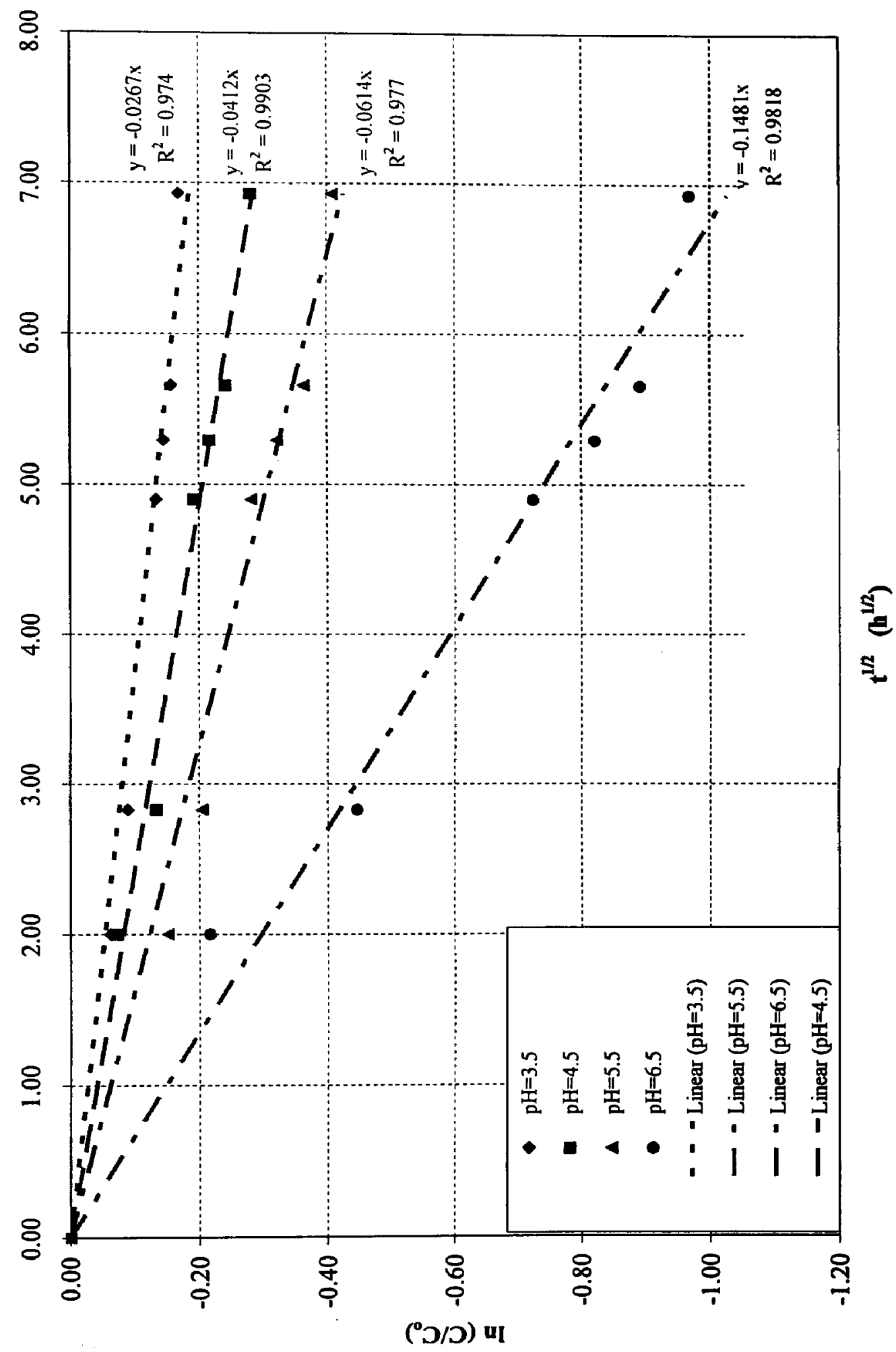


Figure 5.16: Comparison of the percent reduction of $\mathrm{Zn}^{++} \& \mathrm{Ni}^{++}$at different $\mathrm{pH}$

@ Volumetric liquid flux $=0.0231 \mathrm{~m}^{3} \cdot \mathrm{m}^{-2} \cdot \mathrm{s}^{-1} ;$ Temperature $=25^{\circ} \mathrm{C}$; Applied voltage $=4.0 \mathrm{~V} ;$ Current $=46 \mathrm{~mA}$.

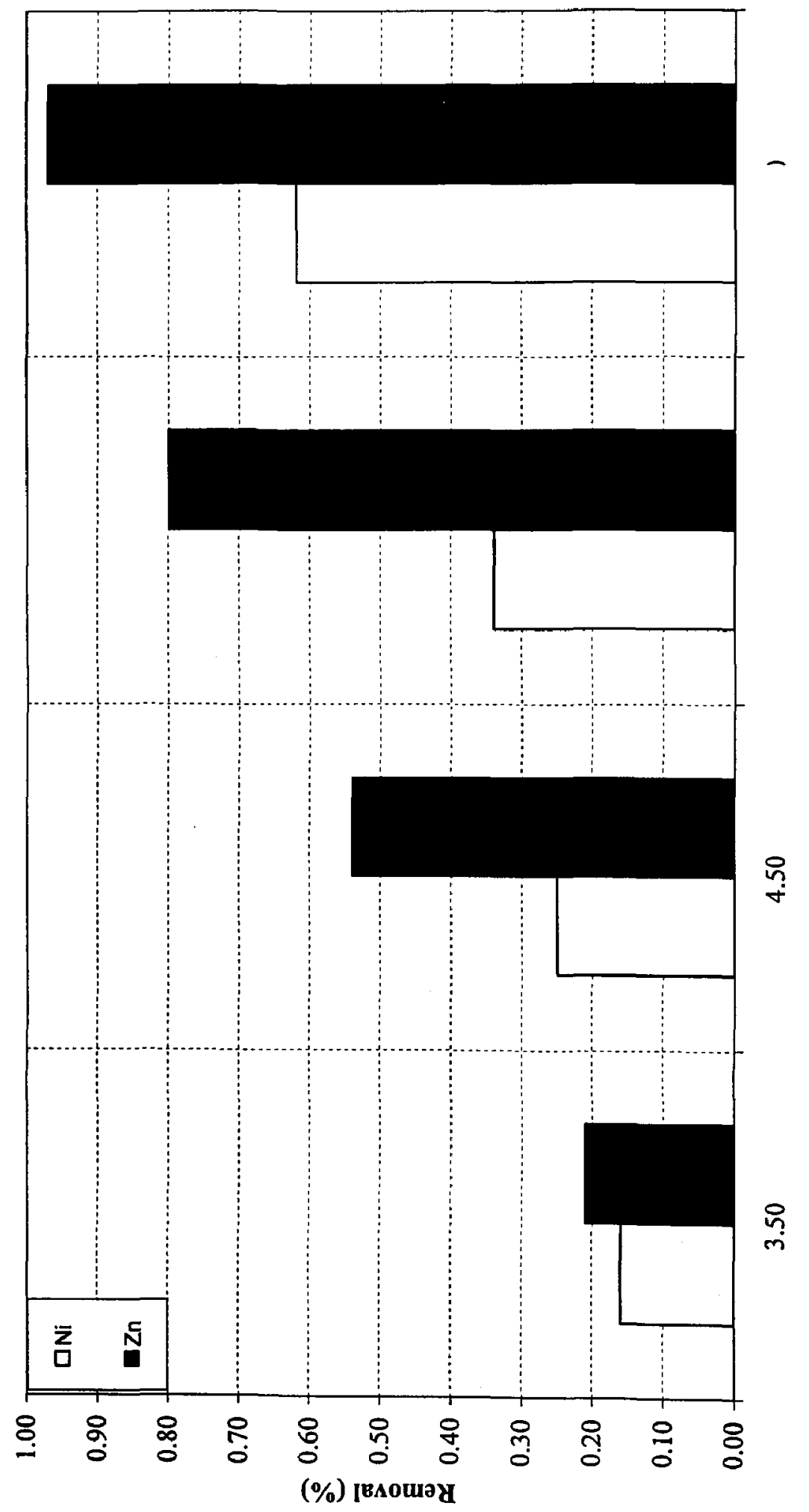


In the strong acidic medium, the rate of hydrogen evolution at the cathode increases, which can cause a decrease in the metal deposition. In the present study, it was believed that the removal of zinc and nickel ions decreased because of the increased evolution of hydrogen at the cathode surface when the $\mathrm{pH}$ was decreased to 3.5 in the acidic medium. It has been reported that at a bulk electrolyte $\mathrm{pH}$ less than 5.5, zinc and nickel deposit as pure metals, while they deposit as a mixture of both metals and hydroxides at $\mathrm{pH}$ greater than 5.5 and complete hydroxide deposits can be achieved at $\mathrm{pH}$ values higher than 9 [33]. 


\subsection{Comparison of Flat and Corrugated Plate Electrodes}

In the present study, the reduction of zinc and nickel was also investigated using both flat plate and corrugated plate electrodes. The surface area of both electrodes was same; it was $0.024 \mathrm{~m}^{2}$. This run was conducted at a volumetric liquid flux of $0.0231 \mathrm{~m}^{3} \cdot \mathrm{m}^{-2} \cdot \mathrm{s}^{-1}$ and a pH of 6.5.

The results for the reduction of zinc ions are presented in Figure 5.17. Approximately $98 \%$ zinc reduction was achieved with the corrugated plate electrode, whereas $97 \%$ was achieved with the flat plate electrode. The difference between the percent reductions of zinc on both types of electrodes is insignificant (only $1 \%$ ); it can be said that corrugated electrodes did not show any improved mass transfer characteristics.

Figure 5.19 presents the percent reduction of nickel ions. There was a slightly higher reduction of nickel ions, $65.5 \%$, using the corrugated plate electrode compared with $62 \%$ using the flat plate electrode. The log-natural plots of the fractional zinc and nickel ion concentrations in the solution verses square root of treatment time are presented in Figures 5.18 and 5.20 , respectively.

Figure 5.21 presents the comparison of percent removal of zinc and nickel ions with flat and corrugated plate electrodes. There was an overall increase of $1.9 \%$ in zinc ions reduction and $3 \%$ in nickel ions reduction when the corrugated electrodes were used. The apparent rate constants were obtained from the log-natural of fraction of zinc and nickel concentrations verses the square root of treatment time. The apparent rate constants and the mass transfer coefficients for zinc and nickel are presented in table 5.6. It may be noted that there are no significant changes in mass transfer coefficients for zinc and nickel ions using either flat plate or corrugated electrodes. 
Table 5.6: Apparent rate constants $(k) \&$ mass transfer coefficients $\left(k_{m}\right)$ for $\mathrm{Zn}^{++} \& \mathrm{Ni}^{++}$ at Flat \& Corrugated plate electrodes

(Applied Voltage $=4.0 \mathrm{~V}$, Current $=46 \mathrm{~mA}$, Electrode surface area $=0.024 \mathrm{~m}^{2} ; \mathrm{pH}=6.5$; Temperature $=25^{\circ} \mathrm{C}$; Volumetric liquid flux $=0.0231 \mathrm{~m}^{3} \cdot \mathrm{m}^{-2} \cdot \mathrm{s}^{-1}$ )

\begin{tabular}{|c|c|c|c|c|}
\hline Type & $\begin{array}{c}\text { Ionic } \\
\text { Species }\end{array}$ & $\begin{array}{c}\text { Removal } \\
(\%)\end{array}$ & $\begin{array}{c}k \\
\left(\mathrm{~h}^{-1 / 2}\right)\end{array}$ & $\begin{array}{c}k_{m} \\
\left(\mathrm{~m}^{-1} \mathrm{~h}^{-1}\right)\end{array}$ \\
\hline Flat Plate & Zinc & 97.0 & 0.548 & 0.143 \\
& Nickel & 62.0 & 0.148 & 0.042 \\
\hline Corrugated & & & & \\
Plate & Zinc & 98.0 & 0.553 & 0.159 \\
& Nickel & 65.5 & 0.145 & 0.046 \\
\hline
\end{tabular}

Tzanetakis et al. [49] studied the mass transfer characteristics of flat and corrugated surfaces. They used parallel plate anodes. The active surface area of the anode was $0.012 \mathrm{~m}^{2}$ and the corrugated cathode area was $0.0003 \mathrm{~m}^{2}$. The distance between the electrodes was $1-4 \mathrm{~mm}$. The range of the Reynolds number was from 125 to 3500 . They obtained much higher values for the mass transfer coefficient using the corrugated electrode; compare with the flat plate electrode, the mass transfer coefficient of the corrugated plate was about 10 times higher in the laminar flow regime, and about 6 times higher in the turbulent region. In the present study, since the surface areas of the anode and the cathode were same $(0.024 \mathrm{~m} 2)$, and the distance between the electrodes was 10 times higher than employed by Tzanetakis et al. [49], no significant difference between mass transfer coefficient for corrugated and flat plate electrodes was observed. 
Figure 5.17: Comparison of the removal of $\mathrm{Zn}^{++}$with flat \& corrugated plate electrodes @ Temperature $=25^{\circ} \mathrm{C} ;$ Volumetric liquid flux $=0.0231 \mathrm{~m}^{3} \cdot \mathrm{m}^{-2} \cdot \mathrm{s}^{-1} ; \mathrm{pH}=5.5$; Voltage $=4.0 \mathrm{~V} ;$ Current $=46 \mathrm{~mA}$.

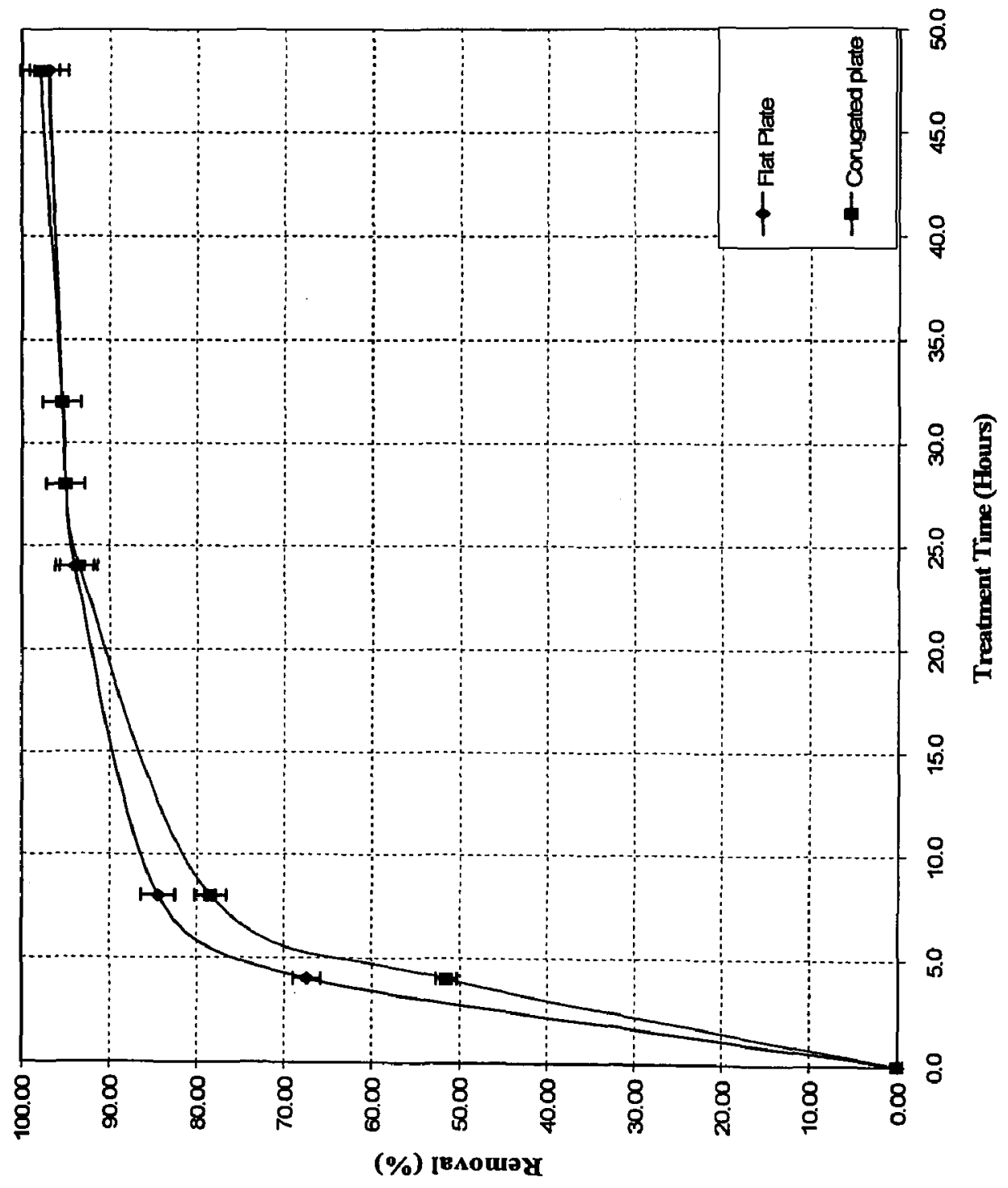


Figure5.18: $\ln \left(\mathrm{C} / \mathrm{C}_{0}\right)$ verses $\mathrm{t}^{1 / 2}$ for $\mathrm{Zn}^{++}$with flat $\&$ corrugated plate electrodes.

(a) Temperature $=25^{\circ} \mathrm{C}$; volumetric liquid flux $0.0231 \mathrm{~m}^{3} \cdot \mathrm{m}^{-2} \cdot \mathrm{s}^{-1} 1 \mathrm{pH}=5.5$;

Voltage $=4.0 \mathrm{~V} ;$ Current $=46 \mathrm{~mA}$.

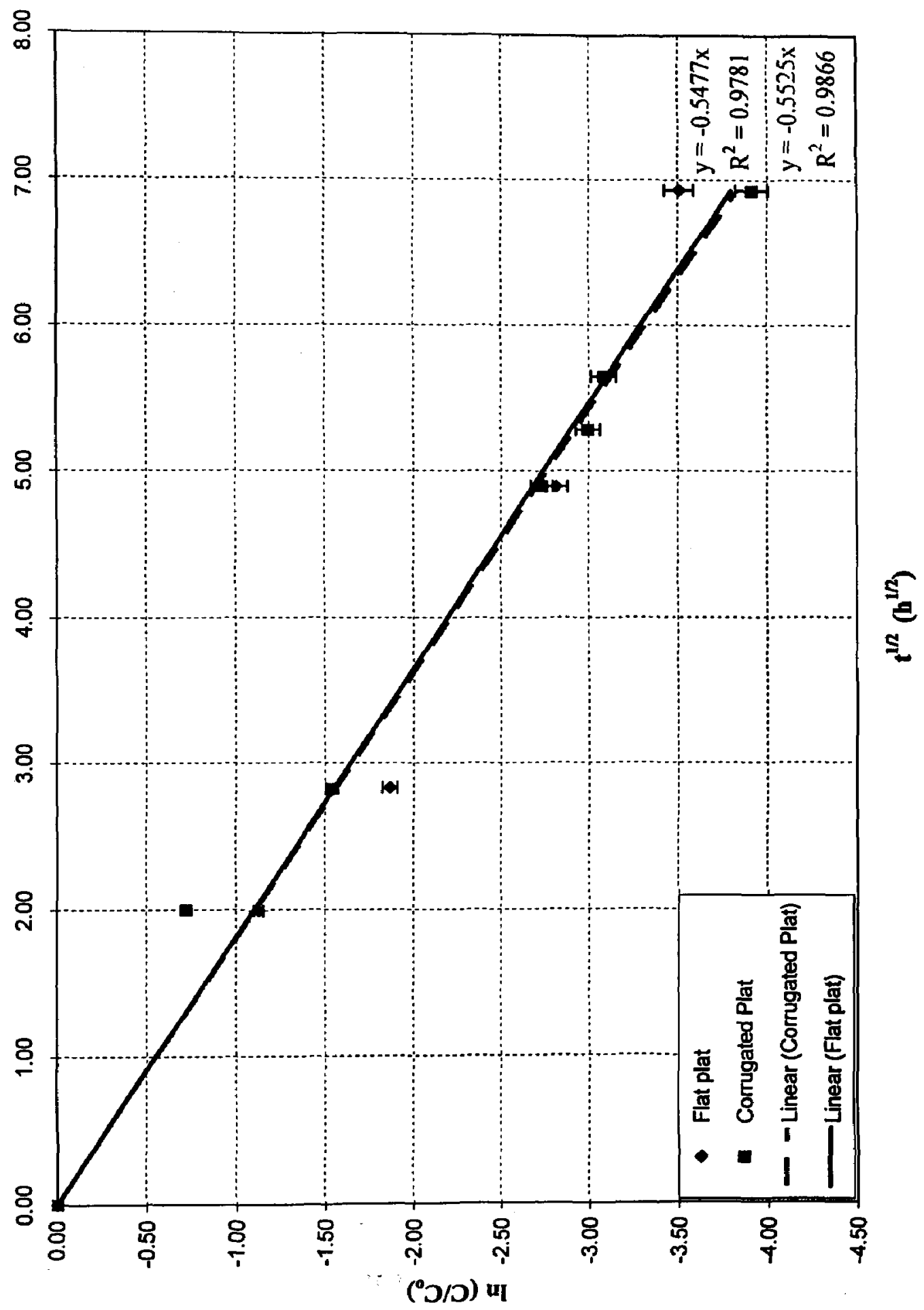


Figure 5.19: Comparison of the removal of $\mathrm{Ni}^{++}$with flat $\&$ corrugated plate electrodes @ Temperature $=25^{\circ} \mathrm{C}$; volumetric flux $=0.0231 \mathrm{~m}^{3} \cdot \mathrm{m}^{-2} \cdot \mathrm{s}^{-1} ; \mathrm{pH}=5.5$;

Applied voltage $=4.0 \mathrm{~V} ;$ Current $=46 \mathrm{~mA}$.

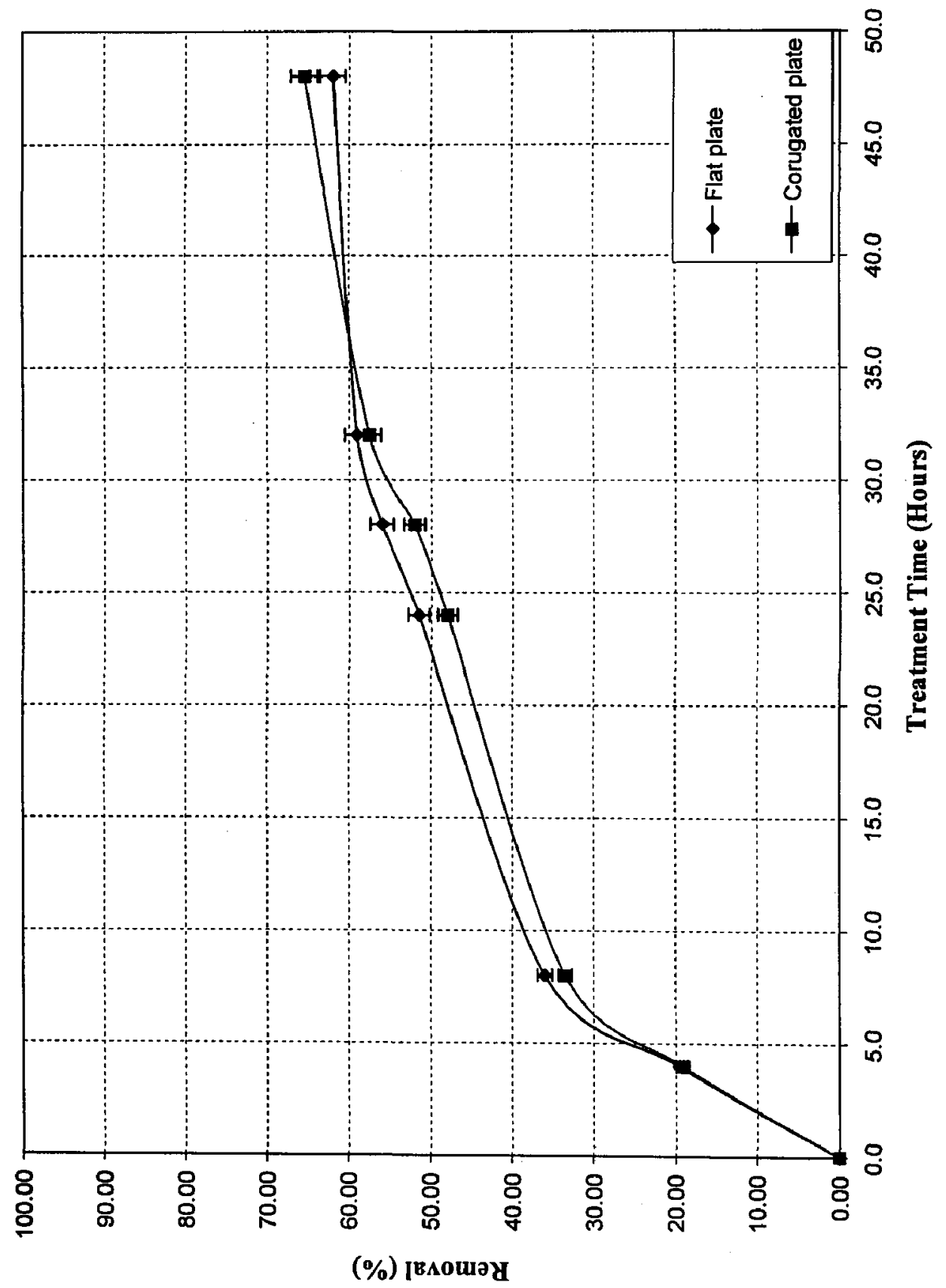


Figure 5.20: In $\left(\mathrm{C} / \mathrm{C}_{0}\right)$ verses $\mathrm{t}^{1 / 2}$ for $\mathrm{Ni}^{++}$with flat \& corrugated plate electrodes.

(@) Temperature $=25^{\circ} \mathrm{C}$; volumetric liquid flux $0.0231 \mathrm{~m}^{3} \cdot \mathrm{m}^{-2} . \mathrm{s}^{-1} 1 ; \mathrm{pH}=5.5$;

Applied voltage $=4.0 \mathrm{~V} ;$ Current $=46 \mathrm{~mA}$.

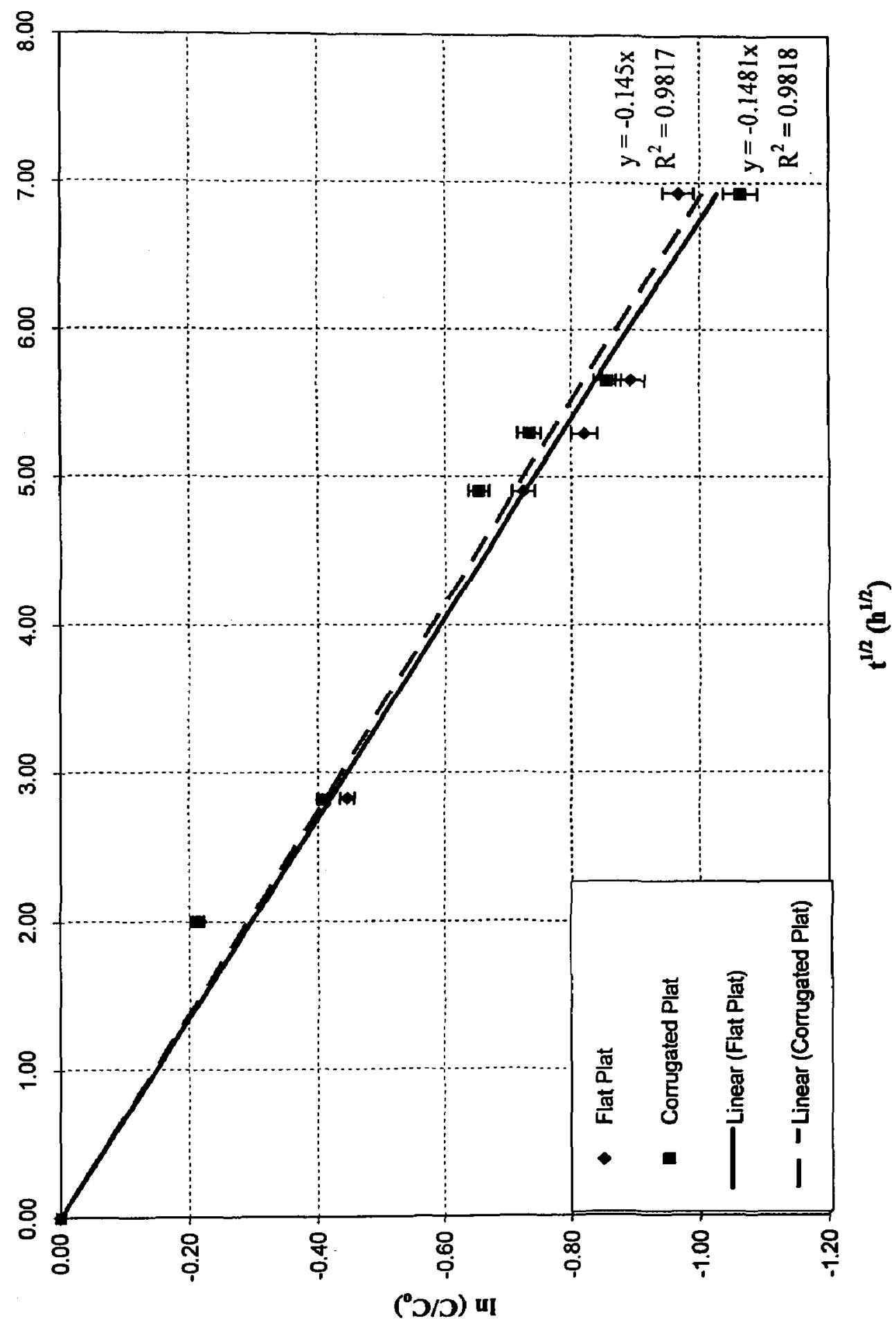


Figure 5.21: Comparison of the percent reduction of $\mathrm{Zn}^{++} \& \mathrm{Ni}^{++}$at flat $\&$ corrugated plate electrodes

@ Temperature $=25^{\circ} \mathrm{C}$; volumetric liquid flux $=0.0231 \mathrm{~m}^{3} \cdot \mathrm{m}^{-2} \cdot \mathrm{s}^{-1} ; \mathrm{pH}=5.5$;

Applied voltage $=4.0 \mathrm{~V} ;$ Current $=46 \mathrm{~mA}$.

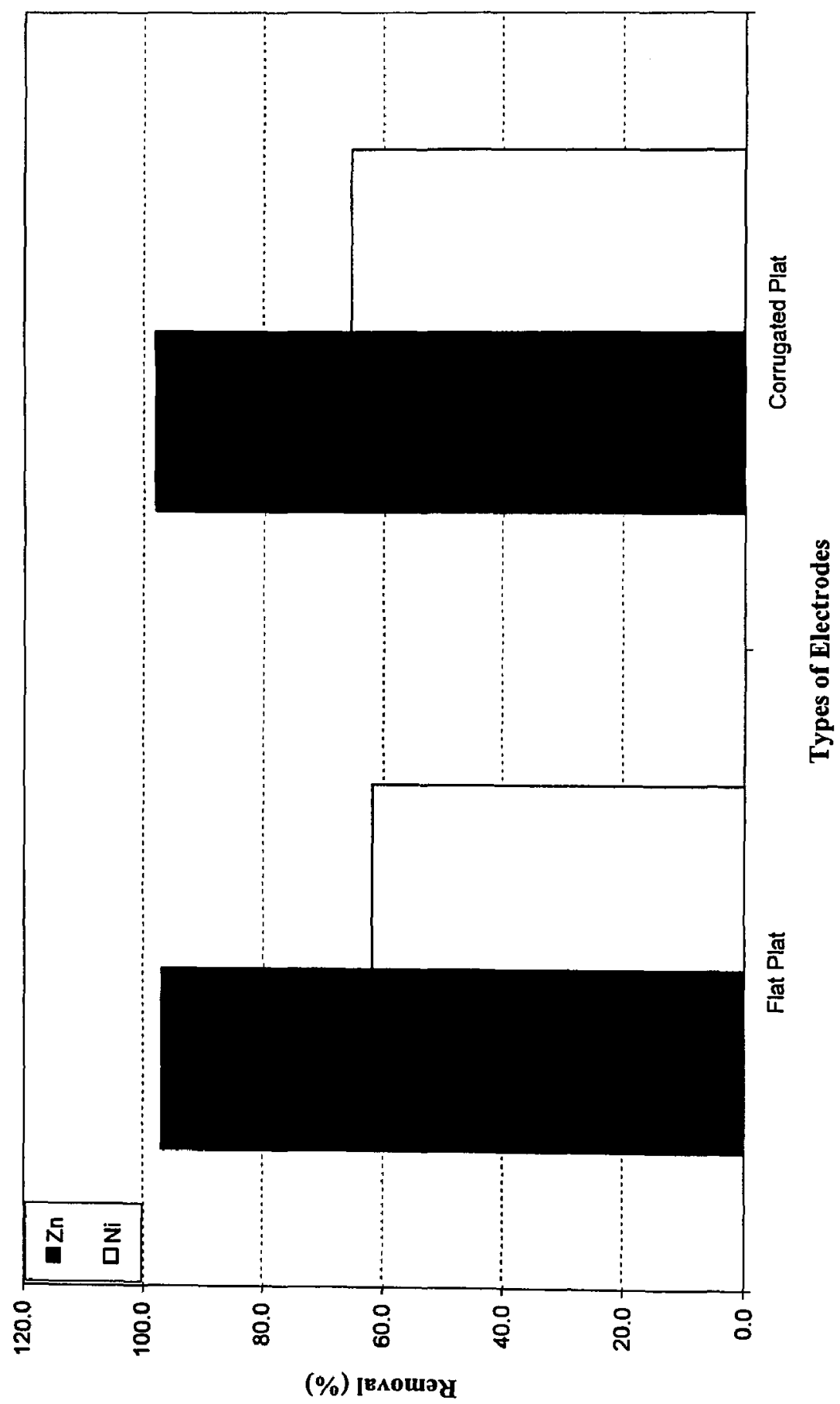




\section{Conclusion}

- In the present study, an increasing trend of the zinc and nickel removal was observed when volumetric flux was increased from 0.0092 to $0.0277 \mathrm{~m}^{3} \cdot \mathrm{m}^{-2} \cdot \mathrm{s}^{-1}$ at a constant temperature of $25^{\circ} \mathrm{C}$ and a $\mathrm{pH}$ of 5.5 . The maximum concurrent removal of zinc and nickel ions, $80 \%$ and $34 \%$, respectively, occurred at a volumetric flux of $0.0231 \mathrm{~m}^{3} \cdot \mathrm{m}^{-2} \cdot \mathrm{s}^{-1}$.

- An increase in the removal of zinc and nickel ions was observed when the $\mathrm{pH}$ was increased from 3.5 to 6.5 ; the maximum removal of zinc and nickel ions, $97 \%$ and $62 \%$, respectively, was achieved at a $\mathrm{pH}$ of 6.5 , and at a constant volumetric liquid flux of $0.0231 \mathrm{~m}^{3} \cdot \mathrm{m}^{-2} \cdot \mathrm{s}^{-1}$.

- The experimental values showed an increase in the metal ions removal when the cathode surface area was increased. The final removal of zinc and nickel ions by $14 \%$ and $12 \%$, respectively, when the surfaces area of cathode was doubled.

- No major changes in the removal of zinc and nickel ions were observed using either flat plate, or corrugated plate electrodes. 


\section{Recommendations}

- A real wastewater sample from an electroplating industry could be used to examine the performance of the apparatus employed in the present study.

- Temperature affects the performance of electrochemical process. It may be beneficial if the reduction of zinc and nickel ions is studied at higher temperatures.

- In an electrochemical cell, the distance between electrodes is of prime importance. More experiments should be performed using different distances between electrodes.

- Further studies should be conducted to investigate the effect of electrode surface area on the removal of zinc and nickel ions. 


\section{References}

[1] http://www.epa.gov/watertrain/step9esa.html

[2] R. K. Turner, D. Pearce, I. Bateman, Environmental Economics, The Johns Hopkins University Press, Baltimore (1993).

[3] Metcalf and Eddy, Wastewater Engineering: Treatment, Disposal, and Reuse, $3^{\text {rd }}$ edition, McGraw-Hill, New York (1991).

[4] C. Polprasert and N. Kongsricharoem, Electrochemical precipitation of chromium from an electroplating wastewater, Water Science Technology, vol. 31 (9), pp. 109-117 (1995).

[5] M. Algarra, M.V. Jimenez, Heavy metals removal from electroplating wastewater by aminopropyl-Si MCM-41, Chemosphere, vol.59 pp.779-786 (2005).

[6] W. W. Eckenfelder, Industrial water pollution control $3^{\text {rd }}$ edition, McGraw Hill, New York (2000).

[7] http://www.afonline.com/articles/00sum04.htm]

[8] United States Environmental Protection Agency. Development document for the final effluent limitations. Guidelines and standard for the metal products \&machinery point source category. US EPA Washington DC. (2003). www.epa.gov

[9] Chapter 681, Sewer, Article I Sewage \& Land drainage, by law no. 457-2000, Toronto Municipal Code Sewer, City of Toronto, Ontario, Canada.

[10] N. Adhoum, L. Monser, N. Bellakhal, J. E. Belgaied, Treatment of electroplating wastewater containing $\mathrm{Cu}^{2+}, \mathrm{Zn}^{2+}$ and $\mathrm{Cr}(\mathrm{VI})$ by electrocoagulation, Journal of Hazardous Materials, vol. B112, pp. 207-213 (2004).

[11] T. Vaughan, C. W. Seo, W. E. Marshall, Removal of selected metal ions from aqueous solution using modified corncobs, Bioresource Technology, vol.78, pp.133-139 (2001).

[12] K. S. Rao, D. Sarangi, P. K. Dash, G. R. Chaudhury, Treatment of wastewater containing copper, zinc, nickel and cobalt using Duolite ES-467, Journal of Chemical Technology and Biotechnology, vol.77, pp.1107-1113 (2002).

[13] H. A. Qdais and H. Moussa, Removal of heavy metals from wastewater by membrane process, Desalination, vol.164, pp.105-110 (2004).

[14] C. Solisio, M. Panizza, P. Paganelli, G. Cerisola, Electrochemical remediation of copper (II) from an industrial effluent Part I: monpolar plate electrode, Resources, 
Conversion and Recycling, vol. 26, pp. 115-124 (1999).

[15] K. Juttner, U. Galla, H. Schmieder, Electrochemical approaches to environmental problems in the process industry, Electrochimica Acta, vol. 45, pp. 2575-2595 (2000).

[16] N. Kongsricharoem and C. Polprasert, Chromium removal by a bipolar electro chemical precipitation process, Water Science Technology, vol. 34 (9), pp. 109-116 (1996).

[17] H. D. Doan, J. Wu, E. Boithi, M. Storrar, Treatment of wastewater using a combined biological and electrochemical technique, Journal of Chemical technology and Biotechnology, vol. 78, pp.632-641 (2003).

[18] www.lenntech.com/electrplating

[19] A. S. Pilla, M. M. E. Duarte, C. E. Mayer, Some aspects of removal of copper from mixed ion dilute solutions, Journal of Applied Electrochemistry, vol. 30, pp. 831-838 (2000).

[20] L. Muresan, G. Maurin, L. Oniciu, S. Avram, Effects of additives on zinc electrowining from industrial waste products, Hydrometallurgy, vol.40, pp.335-342 (1996).

[21] A. J. B. Dutra, P. P. Borges, A. Espinola, Cadmium removal from diluted aqueous solutions by electrowining in a flow by cell, Mineral Engineering, vol. 13, pp. 1139$1148(2000)$.

[22] L. Koene and L. J. J. Janssen, Removal of nickel from industrial process liquids, Electrochimica Acta, vol.47, pp.695-703(2001).

[23] G. Chen, Electrochemical technologies in wastewater treatment, Separation and Purification Technology, vol. 38, pp.11-41 (2004).

[24] D. Pletcher and Walsh, F., Industrial Electrochemistry $2^{\text {nd }}$ edition, Chapman-Hall, London (1990).

[25] C. M. A. Bret and A. M. O. Bret, Electrochemistry Principle, Methods and Applications, Oxford University Press, New York (1993).

[26] P. Atkins and A. Jones, Chemistry: Molecules, Matter and Change $3^{\text {rd }}$ edition, W.H Freeman and Company, New York (1997).

[27] A. Brenner, Electrodeposition of Alloys, Principle and Practice vol.1 \& 2.Academic press, New York, 1963.

[28] J. S. Newman, Electrochemical systems, Prentice-Hall, Englewood Cliffs, New Jersy (1973). 
[29] D. J. Genders and N. Weinberg, Electrochemistry for a Cleaner Environment, Electrosynthesis Company, New York (1992).

[30] S. Ehdaie, M. Fleischmann, R. E. W. Jansson, A. E. Alghaoui, Application of the trickle tower to problems of pollution control I. The scavenging of metal ions, J. Applied Electrochemistry., vol.12, pp.59-67 (1982).

[31] G. Kreysa and C. Reynvaan, Optimal-design of packed bed cells for high conversion, J. Applied Electrochemistry, vol.12 (2), pp.241-251 (1982).

[32] G. Roventi, R. Fratesi, R. A. Guardia, G. Barucca, Normal and anomalous codeposition of Zn-Ni alloys from chloride bath, Journal of Applied Electrochemistry, vol.30, pp.173-179 (2000).

[33] K. N. Njau, M. Woude, C. J. Visser, L. J. J. Janssen, Electrochemical removal of nickel ions from industrial wastewater, Chemical Engineering Journal, vol.79, pp.187-195 (2000).

[34] L. Szpyrkowicz, F. Zilio-Grandi, S. N. Kaul, S. Rigoni-Stern, Electrochemical treatment of copper cyanide wastewaters using stainless steel electrodes, Water Science Technology, vol.38(6), pp.261-268 (1998).

[35] T. Subbaiah, P. Venkateswarula, R. P. Das, G. J. V. J. Raju, Mass transfer conditions at a cathode support plate in an electrochemical cell, Chemical Engineering Processing, vol.34, pp.495-501 (1995).

[36] C. F. Oduoza and A. A. Wragg, Effects of baffle length on mass transfer in a parallel plate rectangular electrochemical cell, Journal of Applied Electrochemistry, vol.30, pp.1439-1444 (2000).

[37] A. Buso, M. Giomo, L. BOaretto, G. Sandona, A. Paratella, New electrochemical reactor for wastewater treatment: Electrochemical Characterization, Chemical Engineering Processing, vol.36, pp.225-260 (1997).

[38] R. Mitzakov, Combined Electrochemical \& Biological Treatment of Industrial wastewater using Porous Electrode and Packed Bed Aerator, Department of Chemical Engineering, Ryerson University (2004).

[39] Y.U. Kim, H.W. Cho, H.S. Lee, C.K. Lee, J.C. Lee, K.I. Rhee, H.J. Sohn, T. Kang, Electrowinning of Palladium using a Modified Cyclone Reactor, Journal of Applied Electrochemistry, vol.32, pp.1235-1239 (2002). 
[40] B.R. Munson, D.F. Young, T.H. Okiishi, Fundamental of Fluid Mechanics 5th edition, John Wiley \& Sons Inc.(2005).

[41] J. R. Taylor, An Introduction to Error Analysis $2^{\text {nd }}$ edition, University Science Books, Sausalito, California (1997).

[42] S. J. Kline and F. A. McClintok, Describing Uncertainties in Single-Sample Experiments, Mechanical Engineering (1953).

[43] J. Crank, The mathematics of diffusion $2^{\text {nd }}$ edition, Oxford University Press (1975).

[44] H. Dahms and M. Croll, The anomalous codeposition of iron nickel alloys, J. Electrochem. Soc., vol.112, pp.771-775 (1965).

[45] K. Higashi, H. Fukushima, T. Adaniya, K. Matsudo, Mechanism of zinc alloys containing a small amount of cobalt, Journal of Electrochemical Society, vol.128, pp.2081-2085 (1981).

[46] F. Miranda, F. J. O. E. Barcia, O. R. Mattos, R. Wiart, Electrodeposition of $\mathrm{Zn-Ni}$ alloys in sulfate electrolytes 1. Experimental approach, J. Electrochem Soc., vol.144, pp.3441-3448 (1997).

[47] E. Chassaing, R. Wiart, Electrocrystallization of Zn-Ni alloys in chloride electrolytes, Electrochimica Acta, vol.37, pp.545-553 (1992).

[48] O. R. Mattos, F. Miranda, F. J. O. E. Barcia, R. Wiart, Electrodeposition of Zn-Ni alloys in sulfate electrolytes 2. Reaction modeling, J. Electrochem Soc., vol.144, pp.3449-3457 (1997).

[49] N. Tzanetakis, K. Scott, W. M. Taama, R. J. J. Jachuck, Mass transfer characteristics of corrugated surfaces, Applied Thermal Engineering, vol.24, pp.1865-1875 (2004).

[50] G. G. Aseyev, Electrolytes Transport Phenomena. Methods for Calculation of Multicomponent Solution and Experimental Data on Viscosities and Diffusion Coefficients, Begell House, New York (1998).

[51] D. W. Green, J. O. Maloney, Perry's Chemical Engineers Handbook $7^{\text {th }}$ edition, McGraw-Hill, New York (1997). 


\section{Appendices}

\subsection{Appendix A: Summary of Experimental Runs}

\subsubsection{Flat Aluminum Cathode \& Stainless Steel Anode}

\section{Run-01}

Conditions: Volumetric liquid flux $=0.0092 \mathrm{~m}^{3} \cdot \mathrm{m}^{-2} \cdot \mathrm{s}^{-1}$; Temperature $=25^{\circ} \mathrm{C} ; \mathrm{pH}=5.5$; Applied voltage $=4.0 \mathrm{~V} ;$ Current $=46 \mathrm{~mA}$; Electrode surface area $=0.024 \mathrm{~m}^{2}$.

\begin{tabular}{|c|c|c|c|c|c|}
\hline $\begin{array}{c}\text { No. of } \\
\text { Observation }\end{array}$ & Time & $\begin{array}{c}\text { Concentration } \\
\text { Of Ni } \\
\text { mg. } .^{-1}\end{array}$ & $\begin{array}{c}\text { Removal } \\
\mathbf{N i} \\
(\mathbf{\%})\end{array}$ & $\begin{array}{c}\text { Concentration } \\
\text { Of Zn } \\
\text { mg. }^{-1}\end{array}$ & $\begin{array}{c}\text { Removal } \\
\mathbf{Z n} \\
(\%)\end{array}$ \\
\hline 1 & 0 & 20.0 & 0.00 & 20.0 & 0.00 \\
2 & 4 & 18.3 & 8.50 & 14.6 & 27.00 \\
3 & 8 & 17.2 & 14.00 & 13.5 & 32.50 \\
4 & 24 & 16.3 & 18.50 & 10.1 & 49.50 \\
5 & 28 & 15.8 & 21.00 & 8.8 & 56.00 \\
6 & 32 & 15.5 & 22.50 & 7.9 & 60.50 \\
7 & 48 & 14.5 & 27.50 & 6.1 & 69.50 \\
\hline
\end{tabular}

\section{Run-02}

Conditions: Volumetric liquid flux $=0.0138 \mathrm{~m}^{3} \cdot \mathrm{m}^{-2} \cdot \mathrm{s}^{-1} ;$ Temperature $=25^{\circ} \mathrm{C} ; \mathrm{pH}=5.5$; Applied voltage $=4.0 \mathrm{~V} ;$ Current $=46 \mathrm{~mA}$; Electrode surface area $=0.024 \mathrm{~m}^{2}$.

\begin{tabular}{|c|c|c|c|c|c|}
\hline $\begin{array}{c}\text { No. of } \\
\text { Observation }\end{array}$ & $\begin{array}{c}\text { Time } \\
\text { (Hours) }\end{array}$ & $\begin{array}{c}\text { Concentration } \\
\text { Of Ni } \\
\text { mg. } .^{-1}\end{array}$ & $\begin{array}{c}\text { Removal } \\
\mathbf{N i} \\
(\%)\end{array}$ & $\begin{array}{c}\text { Concentration. } \\
\text { Of Zn } \\
\text { mg. }^{-1}\end{array}$ & $\begin{array}{c}\text { Removal } \\
\text { Zn } \\
(\%)\end{array}$ \\
\hline 1 & 0 & 20.0 & 0.00 & 20.0 & 0.00 \\
2 & 4 & 17.5 & 12.50 & 14.2 & 29.00 \\
3 & 8 & 16.8 & 16.00 & 13.1 & 34.50 \\
4 & 24 & 16.1 & 19.50 & 9.8 & 51.00 \\
5 & 28 & 15.5 & 22.50 & 8.4 & 58.00 \\
6 & 32 & 15.1 & 24.50 & 7.6 & 62.00 \\
7 & 48 & 14.1 & 29.50 & 5.8 & 71.00 \\
\hline
\end{tabular}




\section{Run-03}

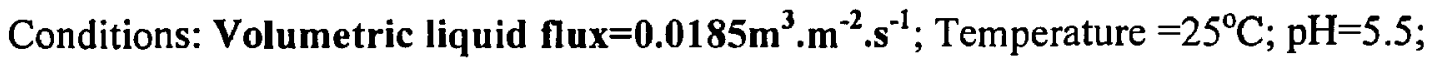

Applied voltage $=4.0 \mathrm{~V} ;$ Current $=46 \mathrm{~mA} ;$ Electrode surface area $=0.024 \mathrm{~m}^{2}$.

\begin{tabular}{|c|c|c|c|c|c|}
\hline $\begin{array}{c}\text { No. of } \\
\text { Observation }\end{array}$ & $\begin{array}{c}\text { Time } \\
\text { (Hours) }\end{array}$ & $\begin{array}{c}\text { Concentration } \\
\text { Of Ni } \\
\mathrm{mg.} .^{-1}\end{array}$ & $\begin{array}{c}\text { Removal } \\
\mathbf{N i} \\
(\%)\end{array}$ & $\begin{array}{c}\text { Concentration } \\
\text { Of Zn } \\
\mathrm{mg.l}^{-1}\end{array}$ & $\begin{array}{c}\text { Removal } \\
\mathbf{Z n} \\
(\%)\end{array}$ \\
\hline 1 & 0 & 20.0 & 0.00 & 20.0 & 0.00 \\
2 & 4 & 17.1 & 14.50 & 14.0 & 30.00 \\
3 & 8 & 16.6 & 17.00 & 12.9 & 35.50 \\
4 & 24 & 15.4 & 23.00 & 9.2 & 54.00 \\
5 & 28 & 15.1 & 24.50 & 7.8 & 61.00 \\
6 & 32 & 14.7 & 26.50 & 6.8 & 66.00 \\
7 & 48 & 13.8 & 31.00 & 4.5 & 77.50 \\
\hline
\end{tabular}

\section{Run-04}

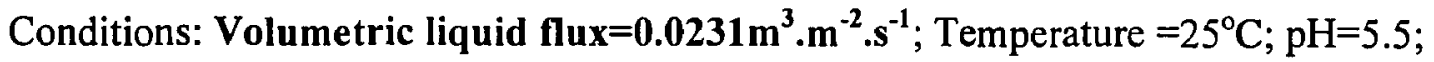
Applied voltage $=4.0 \mathrm{~V} ;$ Current $46 \mathrm{~mA}$; Electrode surface area $=0.024 \mathrm{~m}^{2}$.

\begin{tabular}{|c|c|c|c|c|c|}
\hline $\begin{array}{c}\text { No. of } \\
\text { Observation. }\end{array}$ & $\begin{array}{c}\text { Time } \\
\text { (Hours) }\end{array}$ & $\begin{array}{c}\text { Concentration } \\
\text { Of Ni } \\
\text { mg. } .^{-1}\end{array}$ & $\begin{array}{c}\text { Removal } \\
\text { Ni } \\
(\%)\end{array}$ & $\begin{array}{c}\text { Concentration } \\
\text { Of Zn } \\
\text { mg. } .^{-1}\end{array}$ & $\begin{array}{c}\text { Removal } \\
\mathbf{Z n} \\
(\%)\end{array}$ \\
\hline 1 & 0 & 20.0 & 0.00 & 20.0 & 0.00 \\
2 & 4 & 17.2 & 14.00 & 13.8 & 31.00 \\
3 & 8 & 16.3 & 18.50 & 11.2 & 44.00 \\
4 & 24 & 15.1 & 24.50 & 7.7 & 61.50 \\
5 & 28 & 14.5 & 27.50 & 7.0 & 65.00 \\
6 & 32 & 13.9 & 30.50 & 5.9 & 70.50 \\
7 & 48 & 13.3 & 33.50 & 4.1 & 79.50 \\
\hline
\end{tabular}




\section{Run-05}

Conditions: Volumetric liquid flux $=0.0277 \mathrm{~m}^{3} \cdot \mathrm{m}^{-2} \cdot \mathrm{s}^{-1} ;$ Temperature $=25^{\circ} \mathrm{C} ; \mathrm{pH}=5.5$;

Applied voltage $=4.0 \mathrm{~V} ;$ Current $=46 \mathrm{~mA}$; Electrode surface area $=0.024 \mathrm{~m}^{2}$.

\begin{tabular}{|c|c|c|c|c|c|}
\hline $\begin{array}{c}\text { No. of } \\
\text { Observation }\end{array}$ & $\begin{array}{c}\text { Time } \\
\text { (Hours) }\end{array}$ & $\begin{array}{c}\text { Concentration } \\
\text { Of Ni } \\
\text { mg. } .^{-1}\end{array}$ & $\begin{array}{c}\text { Removal } \\
\text { Ni } \\
(\%)\end{array}$ & $\begin{array}{c}\text { Concentration } \\
\text { Of Zn } \\
\text { mg. }^{-1}\end{array}$ & $\begin{array}{c}\text { Removal } \\
\text { Zn } \\
(\%)\end{array}$ \\
\hline 1 & 0 & 20.0 & 0.00 & 20.0 & 0.00 \\
2 & 4 & 17 & 15.00 & 13.6 & 32.00 \\
3 & 8 & 16.6 & 17.00 & 12.2 & 39.00 \\
4 & 24 & 15.7 & 21.50 & 9.4 & 53.00 \\
5 & 28 & 15.2 & 24.00 & 8.3 & 58.50 \\
6 & 32 & 14.9 & 25.50 & 7.2 & 64.00 \\
7 & 48 & 14.1 & 29.50 & 5.6 & 72.00 \\
\hline
\end{tabular}

\section{Run-06}

Conditions: Volumetric liquid flux $=0.0231 \mathrm{~m}^{3} \cdot \mathrm{m}^{-2} \cdot \mathrm{s}^{-1}$; Temperature $=25^{\circ} \mathrm{C} ; \mathbf{p H}=\mathbf{3 . 5}$;

Applied voltage $=4.0 \mathrm{~V} ;$ Current $=46 \mathrm{~mA} ;$ Electrode surface area $=0.024 \mathrm{~m}^{2}$.

\begin{tabular}{|c|c|c|c|c|c|}
\hline $\begin{array}{c}\text { No. of } \\
\text { Observation }\end{array}$ & Time & $\begin{array}{c}\text { Concentration } \\
\text { Of Ni } \\
\text { mg. } .^{-1} \\
\end{array}$ & $\begin{array}{c}\text { Removal } \\
\mathbf{N i} \\
(\%) \\
\end{array}$ & $\begin{array}{c}\text { Concentration } \\
\text { Of } \mathbf{Z n}_{\mathbf{n}} \\
\mathrm{mg} . \mathrm{l}^{-1} \\
\end{array}$ & $\begin{array}{c}\text { Removal } \\
\text { Zn } \\
(\%) \\
\end{array}$ \\
\hline 1 & $\overline{0}$ & 20.0 & 0.00 & 20.0 & 0.00 \\
\hline 2 & 4 & 18.8 & 6.00 & 18.5 & 7.50 \\
\hline 3 & 8 & 18.3 & 8.50 & 17.4 & 13.00 \\
\hline 4 & 24 & 17.5 & 12.50 & 16.8 & 16.00 \\
\hline 5 & 28 & 17.3 & 13.50 & 16.6 & 17.00 \\
\hline 6 & 32 & 17.1 & 14.50 & 16.3 & 18.50 \\
\hline 7 & 48 & 16.9 & 15.50 & 15.8 & 21.00 \\
\hline
\end{tabular}




\section{Run-07}

Conditions: Volumetric liquid flux $=0.0231 \mathrm{~m}^{3} \cdot \mathrm{m}^{-2} \cdot \mathrm{s}^{-1}$; Temperature $=25^{\circ} \mathrm{C} ; \mathbf{p H}=\mathbf{4 . 5}$;

Applied voltage $=4.0 \mathrm{~V} ;$ Current $=46 \mathrm{~mA} ;$ Electrode surface area $=0.024 \mathrm{~m}^{2}$.

\begin{tabular}{|c|c|c|c|c|c|}
\hline $\begin{array}{c}\text { No. of } \\
\text { Observation }\end{array}$ & $\begin{array}{c}\text { Time } \\
\text { (Hours) }\end{array}$ & $\begin{array}{c}\text { Concentration } \\
\text { Of Ni } \\
\text { mg. } .^{-1}\end{array}$ & $\begin{array}{c}\text { Removal } \\
\mathbf{N i} \\
(\%)\end{array}$ & $\begin{array}{c}\text { Concentration } \\
\text { Of Zn } \\
\text { mg. } .^{-1}\end{array}$ & $\begin{array}{c}\text { Removal } \\
\mathbf{Z n} \\
(\%)\end{array}$ \\
\hline 1 & 0 & 20.0 & 0.00 & 20.0 & 0.00 \\
2 & 4 & 18.6 & 7.00 & 16.6 & 17.00 \\
3 & 8 & 17.5 & 12.50 & 15.1 & 24.50 \\
4 & 24 & 16.5 & 17.50 & 12.5 & 37.50 \\
5 & 28 & 16.1 & 19.50 & 11.7 & 41.50 \\
6 & 32 & 15.7 & 21.50 & 10.7 & 46.50 \\
7 & 48 & 15.1 & 24.50 & 9.30 & 53.50 \\
\hline
\end{tabular}

Run-08

Conditions: Volumetric liquid flux $=0.0231 \mathrm{~m}^{3} \cdot \mathrm{m}^{-2} \cdot \mathrm{s}^{-1}$; Temperature $=25^{\circ} \mathrm{C} ; \mathbf{p H}=\mathbf{5 . 5}$;

Applied voltage $=4.0 \mathrm{~V} ;$ Current $=46 \mathrm{~mA} ;$ Electrode surface area $=0.024 \mathrm{~m}^{2}$.

\begin{tabular}{|c|c|c|c|c|c|}
\hline $\begin{array}{c}\text { No. of } \\
\text { Observation }\end{array}$ & $\begin{array}{c}\text { Time } \\
\text { (Hours) }\end{array}$ & $\begin{array}{c}\text { Concentration } \\
\text { Of Ni } \\
\text { mg. } .^{-1}\end{array}$ & $\begin{array}{c}\text { Removal } \\
\text { Ni } \\
(\%)\end{array}$ & $\begin{array}{c}\text { Concentration } \\
\text { Of Zn } \\
\text { mg. } .^{-1}\end{array}$ & $\begin{array}{c}\text { Removal } \\
\text { Zn } \\
(\%)\end{array}$ \\
\hline 1 & 0 & 20.0 & 0.00 & 20.0 & 0.00 \\
2 & 4 & 17.2 & 14.00 & 13.8 & 31.00 \\
3 & 8 & 16.3 & 18.50 & 11.2 & 44.00 \\
4 & 24 & 15.1 & 24.50 & 7.7 & 61.50 \\
5 & 28 & 14.5 & 27.50 & 7.0 & 65.00 \\
6 & 32 & 13.9 & 30.50 & 5.9 & 70.50 \\
7 & 48 & 13.3 & 33.50 & 4.1 & 79.50 \\
\hline
\end{tabular}




\section{Run-09}

Conditions: Volumetric liquid flux $=0.0231 \mathrm{~m}^{3} \cdot \mathrm{m}^{-2} \cdot \mathrm{s}^{-1} ;$ Temperature $=25^{\circ} \mathrm{C} ; \mathbf{p H}=6.5$;

Applied voltage $=4.0 \mathrm{~V} ;$ Current $=46 \mathrm{~mA} ;$ Electrode surface area $=0.024 \mathrm{~m}^{2}$.

\begin{tabular}{|c|c|c|c|c|c|}
\hline $\begin{array}{c}\text { No. of } \\
\text { Observations }\end{array}$ & $\begin{array}{c}\text { Time } \\
\text { (Hours) }\end{array}$ & $\begin{array}{c}\text { Concentration } \\
\text { Of Ni } \\
\text { mg. } .^{-1}\end{array}$ & $\begin{array}{c}\text { Removal } \\
\mathbf{N i} \\
(\%)\end{array}$ & $\begin{array}{c}\text { Concentration } \\
\text { Of Zn } \\
\text { mg. }^{-1}\end{array}$ & $\begin{array}{c}\text { Removal } \\
\mathbf{Z n} \\
(\%)\end{array}$ \\
\hline 1 & 0 & 20.0 & 0.00 & 20.0 & 0.00 \\
2 & 4 & 16.1 & 19.50 & 6.5 & 67.50 \\
3 & 8 & 12.8 & 36.00 & 3.1 & 84.50 \\
4 & 24 & 9.7 & 51.50 & 1.2 & 94.00 \\
5 & 28 & 8.8 & 56.00 & 1.0 & 95.00 \\
6 & 32 & 8.2 & 59.00 & 0.9 & 95.40 \\
7 & 48 & 7.6 & 62.00 & 0.6 & 97.00 \\
\hline
\end{tabular}

\subsubsection{Surface area of the Cathode and Anode}

\section{Run-10}

Conditions: Volumetric liquid flux $=0.0231 \mathrm{~m}^{3} \cdot \mathrm{m}^{-2} \cdot \mathrm{s}^{-1} ;$ Temperature $=25^{\circ} \mathrm{C} ; \mathrm{pH}=5.5$;

Applied voltage $=4.0 \mathrm{~V} ;$ Current $=46 \mathrm{~mA}$; Electrode surface area $=\mathbf{0 . 0 4 8 \mathrm { m } ^ { 2 }}$.

\begin{tabular}{|c|c|c|c|c|c|}
\hline $\begin{array}{c}\text { No. of } \\
\text { Observations }\end{array}$ & $\begin{array}{c}\text { Time } \\
\text { (Hours) }\end{array}$ & $\begin{array}{c}\text { Concentration } \\
\text { Of Ni } \\
\text { mg. } .^{-1}\end{array}$ & $\begin{array}{c}\text { Removal } \\
\mathbf{~ N i} \\
(\%)\end{array}$ & $\begin{array}{c}\text { Concentration } \\
\text { Of Zn } \\
\text { mg. }^{-1}\end{array}$ & $\begin{array}{c}\text { Removal } \\
\mathbf{Z n} \\
(\%)\end{array}$ \\
\hline 1 & 0 & 20.0 & 0.00 & 20.0 & 0.00 \\
2 & 4 & 16.1 & 19.50 & 11.7 & 67.50 \\
3 & 8 & 15.8 & 36.00 & 7.7 & 84.50 \\
4 & 24 & 13.8 & 51.50 & 3.5 & 94.00 \\
5 & 28 & 13.1 & 56.00 & 2.6 & 95.00 \\
6 & 32 & 12.8 & 59.00 & 2.1 & 95.40 \\
7 & 48 & 10.8 & 62.00 & 1.2 & 97.00 \\
\hline
\end{tabular}




\subsubsection{The Corrugated Cathode and Anode Plate}

\section{Run-11}

Conditions: Volumetric liquid flux $=0.0231 \mathrm{~m}^{3} \cdot \mathrm{m}^{-2} \cdot \mathrm{s}^{-1} ;$ Temperature $=25^{\circ} \mathrm{C} ; \mathrm{pH}=6.5$;

Applied voltage $=4.0 \mathrm{~V} ;$ Current $=46 \mathrm{~mA}$; Electrode surface area $=0.024 \mathrm{~m}^{2}$.

\begin{tabular}{|c|c|c|c|c|c|}
\hline $\begin{array}{c}\text { No. of } \\
\text { Observations }\end{array}$ & $\begin{array}{c}\text { Time } \\
\text { (Hours) }\end{array}$ & $\begin{array}{c}\text { Concentration } \\
\text { Of Ni } \\
\text { mg. } .^{-1}\end{array}$ & $\begin{array}{c}\text { Removal } \\
\mathbf{N i} \\
(\%)\end{array}$ & $\begin{array}{c}\text { Concentration } \\
\text { Of Zn } \\
\text { mg. }^{-1}\end{array}$ & $\begin{array}{c}\text { Removal } \\
\mathbf{Z n} \\
(\%)\end{array}$ \\
\hline 1 & 0 & 20.0 & 0.00 & 20.0 & 0.00 \\
2 & 4 & 16.2 & 19.50 & 9.7 & 67.50 \\
3 & 8 & 13.3 & 36.00 & 4.3 & 84.50 \\
4 & 24 & 10.4 & 51.50 & 1.3 & 94.00 \\
5 & 28 & 9.6 & 56.00 & 1.0 & 95.00 \\
6 & 32 & 8.5 & 59.00 & 0.9 & 95.40 \\
7 & 48 & 6.9 & 62.00 & 0.4 & 97.00 \\
\hline
\end{tabular}




\subsection{Appendix B}

\subsubsection{Viscosity and Density Calculation}

The dynamic viscosity of the simulated wastewater was calculated from the method described in [50].The dynamic viscosity of a multicomponent electrolytic solution can be calculated from the following expression:

$$
\eta=\eta_{o} \exp V
$$

In the above expression $\eta_{o}$ is the viscosity of water, which was obtained from Perry's Chemical Engineers' Handbook [51] at the experimental temperature. $V$ was given by the following equation:

$$
V=\sum_{i=1}^{k} c_{i}\left(A_{0 i}+A_{1 i} t+A_{2 i} c_{i}+A_{3 i} t\right)
$$

In the above expression, $c_{i}$ is the percent mass fraction of species $i, A_{i j}$ are coefficients for each electrolyte. The reported percent error of these coefficients for zinc sulfate, nickel sulfate and potassium sulfate was $2.39 \%, 1.54 \%$, and $0.30 \%$, respectively.

To determine the mass fraction of each species the density of the solution was required. The density of the solution was calculated from the following formula:

$$
\rho=\rho_{o}+\sum_{i=1}^{k} c_{i}\left(B_{1 i}+B_{2 i} t+B_{3} c_{i}\right)
$$

In the above expression $\rho_{o}$ is the density of water $\left(\mathrm{kg} \cdot \mathrm{m}^{-3}\right), B_{i j}$ are the coefficients for the electrolytic species present. The reported error for these coefficients for zinc sulfate, nickel sulfate and potassium sulfate was $0.27 \%, 0.23 \%$ and $0.13 \%$, respectively. The density of the water was obtained from Perry's Chemical Engineers Handbook [51] at the experimental temperature of $25^{\circ} \mathrm{C}$.

The density expression required the \% mass fraction of each species. An iterative process was required of this. Therefore, the following expression was used with an initial value of the density of the solution selected: 


$$
c_{i}=\frac{100 M_{i} C_{i}}{\rho}
$$

In the above expression, $c_{i}$ is the mass fraction of species, $M_{i}$ is the molecular weight of the species, and $C_{i}$ is the mass concentration of the species. The mass fraction of each species was determined when a prescribed tolerance was reached. With the mass fraction calculated, the dynamic viscosity of the solution was calculated from equation (1).

The density and viscosity calculated for a multicomponent electrolytic solution with concentration of $20 \mathrm{ppm}$ for zinc and nickel, and $500 \mathrm{ppm}$ for potassium sulfate were:

- Density $=997.31 \mathrm{~kg} \cdot \mathrm{m}^{-3}$

- Viscosity $=0.00087 \mathrm{~kg} \cdot \mathrm{m}^{-1} \cdot \mathrm{s}^{-1}$

\subsubsection{Calculation of Reynolds Number}

Once the dynamic viscosity and density were known, the Reynolds numbers for different volumetric liquid fluxes were calculated from the equation 4.1.

$$
R_{e}=\frac{\rho u D_{h}}{\mu}
$$

- Density $=\rho=997.31 \mathrm{~kg} \cdot \mathrm{m}^{-3}$

- Viscosity $=\mu=0.00087 \mathrm{~kg} \cdot \mathrm{m}^{-1} \cdot \mathrm{s}^{-1}$

- Hydraulic diameter $=D_{h}=0.068 \mathrm{~m}$

\begin{tabular}{|c|c|}
\hline $\begin{array}{c}\text { volumetric } \\
\text { flux } \\
\mathrm{m}^{3} \cdot \mathrm{m}^{-2} \cdot \mathrm{s}^{-1}\end{array}$ & $\begin{array}{c}\text { Reynolds No. } \\
\mathrm{R}_{\mathrm{e}}\end{array}$ \\
\hline 0.0092 & 717.15 \\
0.0138 & 1075.72 \\
0.0185 & 1442.09 \\
0.0231 & 1800.66 \\
0.0277 & 2159.23 \\
\hline
\end{tabular}




\subsection{Appendix C: Sample Calculations}

\subsubsection{Calculation of the Mass Transfer Coefficient}

The mass transfer coefficients for nickel and zinc were calculated using average metal ions concentration $\left(C^{\prime}\right)$ and the change in metal ions concentration $(\triangle C)$ during the specific time interval $(\Delta t)$, volume of the solution $(V)$, area of the electrode $\left(A_{e}\right)$

$$
k_{m}=\frac{\Delta C V}{\Delta t A e C^{\prime}}
$$

One sample calculation for determining $k_{m}$ for zinc at a volumetric liquid flux $0.0231 \mathrm{~m}^{3} \cdot \mathrm{m}^{-}$ ${ }^{2} . \mathrm{s}^{-1}$ and at $\mathrm{pH} 6.5$ is shown below in Table -1 :

Table -1: Mass transfer coefficient for $\mathrm{Zn}$

\begin{tabular}{|c|c|c|c|c|c|}
\hline $\begin{array}{c}\text { Time } \\
\text { (t) } \\
\text { (Hours) }\end{array}$ & $\begin{array}{l}\text { Conc. } \\
\text { of } \mathrm{Zn} \\
\text { (C) } \\
(\mathrm{mg} / \mathrm{l})\end{array}$ & $\begin{array}{l}\Delta t=\left(t_{2}-t_{1}\right) \\
\text { (Hours) }\end{array}$ & $\begin{array}{c}\Delta \mathrm{C}=(\mathrm{C} 1-\mathrm{C} 2) \\
(\mathrm{mg} / \mathrm{l})\end{array}$ & $\begin{array}{c}\mathrm{C}_{\mathrm{avg}}=\left(\mathrm{C}_{1}+\mathrm{C}_{2}\right) / 2 \\
(\mathrm{mg} / \mathrm{l})\end{array}$ & $\begin{array}{c}\mathrm{k}_{\mathrm{m}} \\
(\mathrm{cm} / \mathrm{h})\end{array}$ \\
\hline 0.00 & 20.00 & 4.00 & 13.50 & 13.25 & 2.123 \\
\hline 4.00 & 6.50 & 4.00 & 3.40 & 4.80 & 1.476 \\
\hline 8.00 & 3.10 & 16.00 & 1.90 & 2.15 & 1.841 \\
\hline 24.00 & 1.20 & 4.00 & 0.20 & 1.10 & 0.379 \\
\hline 28.00 & 1.00 & 4.00 & 0.08 & 0.96 & 0.174 \\
\hline 32.00 & 0.92 & 16.00 & 0.32 & 0.76 & 0.877 \\
\hline 48.00 & 0.60 & & & & \\
\hline & & & & Avg $k_{m}$ & 0.143 \\
\hline
\end{tabular}

where $\mathrm{V}=0.05 \mathrm{~m}^{3}$, volume of the solution

$$
\mathrm{A}_{\mathrm{e}}=0.024 \mathrm{~m}^{2,} \text { area of electrode. }
$$




\subsubsection{Uncertainty in Mass Transfer Coefficient}

The mass transfer coefficient was given by the following expression:

$$
k_{m}=\frac{\Delta C V}{\Delta t A e C^{\prime}}
$$

The uncertainties associated with the mass transfer coefficients for zinc and nickel were calculated by the method of Kline and McClintock based on the following error propagation equation [42]:

$$
\sigma^{2} x \approx \sigma^{2} u\left(\frac{\partial x}{\partial u}\right)^{2}+\sigma^{2} v\left(\frac{\partial x}{\partial v}\right)^{2}+\ldots \ldots
$$

Based on equation Eq.-2, the uncertainty associated with the mass transfer coefficient was given by

$$
k_{m}=\sqrt{\left(\frac{\partial k m}{\partial \Delta C} \cdot \sigma_{\Delta C}\right)^{2}+\left(\frac{\partial k m}{\partial V} \cdot \sigma_{V}\right)^{2}+\left(\frac{\partial k m}{\partial \Delta t} \cdot \sigma_{\Delta t}\right)^{2}+\left(\frac{\partial k m}{\partial A e} \cdot \sigma_{A e}\right)^{2}+\left(\frac{\partial k m}{\partial C^{\prime}} \cdot \sigma_{C^{\prime}}\right)^{2}}
$$

A sample calculation for determining the uncertainty linked with mass transfer coefficient for zinc (Run 09: at pH6.5 and $0.0231 \mathrm{~m}^{3} \cdot \mathrm{m}^{-2} \cdot \mathrm{s}^{-1}$ ) is provided below.

1. The uncertainty associated with $\Delta C$ in time interval $\Delta t$ was calculated by multiplying the total concentration change in 48 hours by standard deviation for zinc $\left(0.014 \mathrm{mg} . \mathrm{l}^{-1}\right)$ :

$$
\sigma_{\Delta C}=\Delta C \times 0.014=19.4 \times 0.014=0.272 \mathrm{mg} . l^{-1}
$$

2. Similarly, the uncertainty for average concentration $\left(C^{\prime}\right)$ was:

$$
\sigma_{C^{\prime}}=C^{\prime} \times 0.014=10.3 \times 0.014=0.144 m g . l^{-1}
$$

3. The uncertainty in total volume of the electrolyte was based on a $4000 \mathrm{ml}$ Erlenmeyer flask, which was used to make scale markings on the holding tank to a total of 50 liters of 
solution. The flask had an uncertainty of $\pm 5 \%$ or $\pm 200 \mathrm{ml}$. For 50 liters of solution, the total uncertainty was:

$$
\sigma_{V}=12(4000 \pm 200) m l+2000 \pm 100 \mathrm{ml}=50000 \pm 2500 \mathrm{ml} \cong 50 \pm 2.5 l \text {, or } \sigma_{v}=0.0025 \mathrm{~m}^{3}
$$

4. The uncertainty in electrode surface area was based on the graduations of the measuring tape used. The smallest graduation was $1 \mathrm{~mm}$. The relative uncertainty associated with electrode area (cathode) was calculated by the following expression:

$$
\text { Relative uncertainty }=\sqrt{\left(\frac{0.1}{6}\right)^{2}+\left(\frac{0.1}{20}\right)^{2}}=1.58 \%
$$

Or

$$
\sigma_{A e}=0.0158(0.024) \mathrm{m}^{2}=3.79 \times 10^{-4} \mathrm{~m}^{2}
$$

5. The uncertainty associated with time was based on an assumed error of 5 seconds in an hour, and for 48 hours of electrolysis time it amounted to

$$
\sigma_{\Delta t}=48 \times 5 / 3600=0.067 h
$$

The uncertainty associated with $k_{m}$ was determined by calculating the five terms in equation Eq.-3 one by one

$$
\begin{aligned}
& \left(\frac{V}{\Delta t \cdot A e . C^{\prime}} \times \sigma_{\Delta C}\right)^{2}=\left(\frac{0.05}{48 \times 0.024 \times 10.3} \times 0.272\right)^{2}=1.31 \times 10^{-6} \mathrm{~m} . \mathrm{h}^{-1} \\
& \left(\frac{\Delta C}{\Delta t \cdot A e \cdot C^{\prime}} \times \sigma_{V}\right)^{2}=\left(\frac{19.4}{48 \times 0.024 \times 10.3} \times 0.0025\right)^{2}=1.67 \times 10^{-5} \mathrm{~m} \cdot \mathrm{h}^{-1} \\
& \left(\frac{\Delta C}{(\Delta t)^{2} \cdot A e . C^{\prime}} \times \sigma_{\Delta t}\right)^{2}=\left(\frac{19.4 \times 0.05}{(48)^{2} \times 0.024 \times 10.3} \times 0.067\right)^{2}=1.30 \times 10^{-8}{\mathrm{~m} . \mathrm{h}^{-1}}^{2}
\end{aligned}
$$




$$
\begin{gathered}
\left(\frac{\Delta C}{\Delta t \cdot(A e)^{2} \cdot C^{\prime}} \times \sigma_{A e}\right)^{2}=\left(\frac{19.4 \times 0.05}{48 \times(0.024)^{2} \times(10.3)} \times 3.79 \times 10^{-4}\right)^{2}=1.66 \times 10^{-6} \mathrm{~m} \cdot \mathrm{h}^{-1} \\
\left(\frac{\Delta C}{\Delta t \cdot A e \cdot\left(C^{\prime}\right)^{2}} \times \sigma_{C^{\prime}}\right)^{2}=\left(\frac{19.4 \times 0.05}{48 \times 0.024 \times(10.3)^{2}} \times 0.144\right)^{2}=1.3 \times 10^{-6} \mathrm{~m} \cdot \mathrm{h}^{-1}
\end{gathered}
$$

Or

$$
k_{m}=\sqrt{(1.31+1.66+1.30) \times 10^{-6}+1.67 \times 10^{-5}+1.3 \times 10^{-8}}=4.58 \times 10^{-3} m . h^{-1}
$$

Similarly, the uncertainty associated with the mass transfer coefficient for nickel (Run 09: at pH 6.5 and $0.0231 \mathrm{~m}^{3} \cdot \mathrm{m}^{-2} \cdot \mathrm{s}^{-1}$ ) was found to be $2.18 \times 10^{-3} \mathrm{~m} \cdot \mathrm{h}^{-1}$.

(2) BC.74 188 